\title{
MANUAL of \\ SCIHNAIC
}

\section{RUSSIAN}

tingsy

$P Q$

2120

M 33

\section{THOMAS F. MAGNER}

\author{
PRENTICE-HALL
}




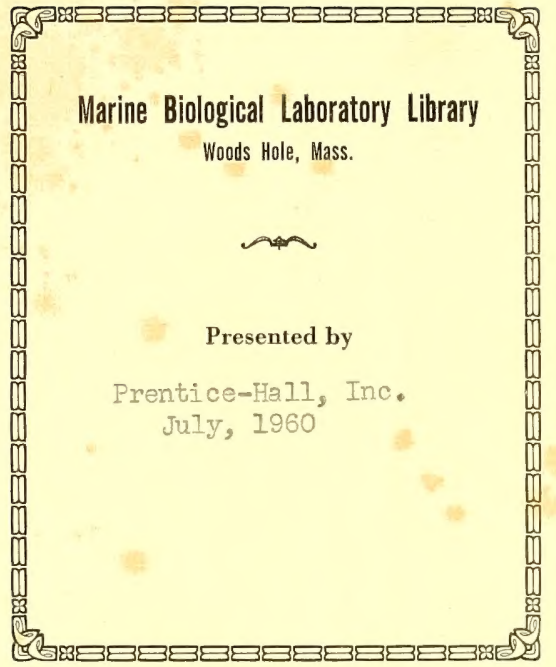




\title{
Manual of
}

\section{SCIENTIFIC RUSSIAN}

\author{
by \\ THOMAS F. MAGNER, Ph.D. \\ Chairman, Department of Slavic Studies \\ Pennsylvania State University
}

Englewood Cliffs, N. J.

PRENTICE-HALL, INC. 
(C) $1958 \mathrm{by}$

PRENTICE-HALL, INC.

Englewood Cliffs, N. J.

All rights reserved. No part of this book may be reproduced in any form, by mimeograph or any other means, without permission in writing from the publishers.

Library of Congress Catalog Card No. 58-12482 


\section{TABLE OF CONTENTS}

\section{INTRODUCTION}

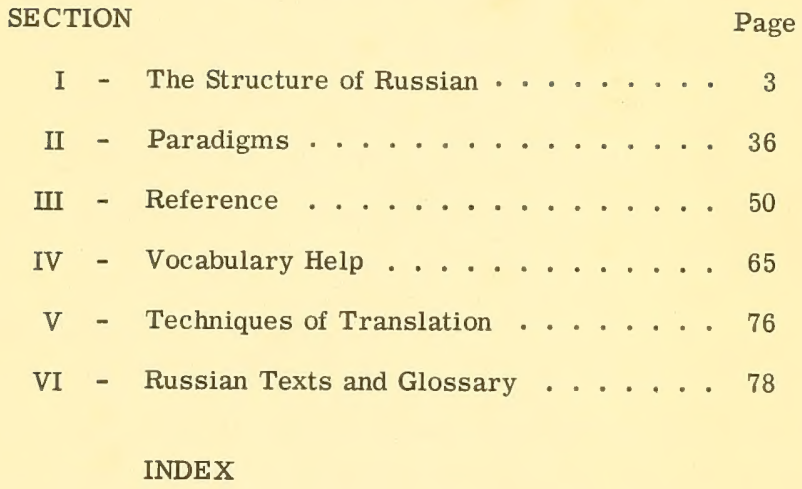


, 
Though the "sputniks" whirling around in space provide the most dramatic evidence of the present need for reading Russian scientific texts, Russian contributions in other fields had already stimulated many American scientists to study the Russian language. Their motivation must indeed have been of a high order, since present textbooks are hardly adequate for the specialized task of developing rapidly an ability to read involved Russian texts. To meet the pressing need for a serious textbook in this area, the writer offers this manual with the hope that its use will enable American scientists to establish scholarly communication with their Russian counterparts.

\section{What is Scientific Russian?}

All texts written in the Russian language are Russian, whether they deal with algae or water nymphs. What is referred to here as Scientific Russian is simply that Russian textual maiter which deals with scientific subjects. The reference to texts implies that the written language, rather than the spoken idiom, is the main object of interest. This limitation of interest eliminates from consideration a host of complications, ranging from pronunciation problems to the vagaries of idiomatic usage. For an adult the attainment of a skill in reading a foreign language is far easier than the acquisition of even a modest fluency in the spoken language.

This manual will thus prepare the learner to read standard written Russian and will, by the consideration of scientific texts, provide opportunities for familiarization with Russian scientific terminology.

\section{Discussion of the Problem}

For the speaker of English the Russian language presents initially a formidable appearance: a dense thicket of inflectional forms further obscured by a strange alphabet. 
The large, similar-appearing word stock which English shares with languages such as French and Spanish is not a common property of English and Russian. However, the scientist has one distinct advantage in the matter of vocabulary, since specific scientific terms in both languages may be quite similar, e.g. Russian fil'tratsiya, "filtration".

Difficulties there are in the learning process, but they need not be exaggerated. The Russian language is an effective instrument of communication, serving, as it does, as the general administrative language for the 210 millions of people in the Soviet Union. Like all other languages, Russian has a definite system of sounds and sound combinations. This language system is very efficiently represented by the Russian Cyrillic alphabet, far more efficiently, in fact, than the English language is served by its antiquated orthography.

The writer assumes that the typical user of this manual will be used to working with complex systems and so will not be intimidated by linguistic complexity. All of the complications of Russian appear at the very outset of the learner's effort, and thus a short period of uncertainty(sometimes bewilderment) is to be expected. But there is a definite limit to the grammatical complexities of Russian, and the learner, sooner or later, reaches a stage where form identification becomes almost an automatic process. On the assumption, then, that the potential user of this work is a mature person, used to complex structures, the writer has dispensed with the slow, shock-avoiding approach of the multi-purpose textbook. The structure of the Russian language has been described as briefly and efficiently as possible, so that the learner may begin at an early stage to read the Russian texts contained in the manual.

\section{Divisions of the Manual}

This book is designed to serve both as a textbook in the development of the reading skill and, thereafter, as a reference book of Russian structure. As a textbook, it may be used: 1) in an organized course of Scientific Russian, 2) in conjunction with a workbook, or 3) by itself in a program of self-study. The last situation will be, quite obviously, the most demanding. As a reference, it is divided into definite sections, so that a person who reads Russian regularly may need to consult only one section, while the occasional reader may require the help of two or more such sections. The learner is advised to spend an hour or so in 'browsing' through the manual, acquainting himself with its contents. 


\section{SECTION I \\ THE STRUCTURE OF RUSSIAN}

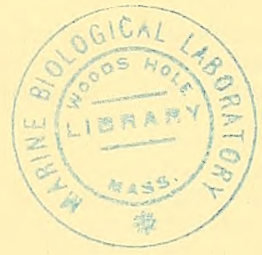

\section{RUSSIAN LETTERS AND SOUNDS}

Even though a student is learning only to read Russian, he will find it necessary to vocalize the Russian letters in some way. Since he may have, at a later stage, the opportunity to speak Russian, it would be wise for him to approximate the standard Russian pronunciation from the very beginning of his studies. The brief description of pronunciation below would be well supplemented by the acquisition of a tape or disc recording of Russian sounds.*

The following six Russian letters are similar, both in appearance and sound value, to six English letters:

$\begin{array}{lllll}\text { A } & \text { a } & \text { A } & \text { a (as in father) } \\ \text { H } & \text { H } & \text { K } & k & \\ M & M & M & m \\ 0 & 0 & 0 & 0 \\ \text { T } & \text { T } & \text { T } & \text { t } \\ 3 & 3 & \text { Z } & \text { Z }\end{array}$

$\begin{array}{ll}\text { a } & \text { "and, but" } \\ \text { как } & \text { "how, as" } \\ \text { мama. } & \text { "mama" } \\ \text { oм } & \text { "ohm" } \\ \text { так } & \text { "so, thus" } \\ \text { hoзa } & \text { "goat" }\end{array}$

The letters below are similar in sound value, though dissimilar in appearance, to certain English letters:

\begin{tabular}{|c|c|c|c|c|}
\hline$\sigma$ & B & $\mathrm{b}$ & бомба & "bomb" \\
\hline B & V & $\mathrm{v}$ & ваза & "vase" \\
\hline$\Gamma$ & G & $\begin{array}{l}g \text { (as in get, not } \\
\text { as in general) }\end{array}$ & Гемма & "gamma" \\
\hline Д & D & $\mathrm{d}$ & погма & "dogma" \\
\hline H & - & $\begin{array}{l}\text { - (like } z \text { in azure } \\
\text { or } \underline{s} \text { in pleasure) }\end{array}$ & жаба & "toad" \\
\hline$\breve{И}$ & $Y$ & $\mathrm{y}$ & мaй & "May" \\
\hline$\pi$ & L & 1 & лава & "lava" \\
\hline $\mathrm{H}$ & $\mathrm{N}$ & $\mathrm{n}$ & нота & "note" \\
\hline$\Pi$ & P & $p$ & пакт & "pact" \\
\hline P & $\mathrm{R}$ & $r$ (tongue-t1p trilled) & ротатор & "rotator" \\
\hline C & $S$ & $\mathrm{~s}$ & сопа & "soda" \\
\hline do & $\mathrm{F}$ & f & флот & "fleet" \\
\hline
\end{tabular}

Four Russian letters have sound values also present in English, where they are usually represented by two or more letters. They are:

\begin{tabular}{|c|c|c|c|c|}
\hline II & TS & ts (as in cats) & цапdһa & "trunnion" \\
\hline ч & $\mathrm{CH}$ & (as in cheese) & yac & "hour" \\
\hline III & SH & (as in shush) & птат & "state" \\
\hline щ & SHCH & shch (as in fresh cheese) & борщ & "beet soup" \\
\hline
\end{tabular}

*The only inexpensive recording known to the writer is an excellent vinylite record ( $7^{\prime \prime}, 33$ 1/3 micro-groove) produced by the EMC Recording Company(806 East 7 th street, St. Paul 6, Minn.). The price is one dollar, post-paid. 
One Russian letter has a sound not similar to any English speech sound, though it is quite similar to the friction sound made in the back of the mouth when one prepares to expectorate. It is similar to $\mathrm{ch}$ in German ach.

$$
\mathrm{X} X \quad \mathrm{XaH} \quad \text { "khan" }
$$

All of the letters and their sounds treated above are called consonants, with the exception of the two vowels a and o. Russian vowels are all similar in sound to English vowels with one exception, namely,

$$
\text { b Ы CHH "son" }
$$

This Russian sound may be approximated by pronouncing the English sound oo (as in the

\begin{tabular}{|c|c|c|c|}
\hline и & (like ee in meet) & литр & "liter" \\
\hline $\mathrm{y}$ & (like $\overline{\text { oo }}$ in $\overline{\text { toot }}$ ) & тут & "here" \\
\hline$\theta$ & (like $\overline{\text { e in bet) }}$ & поэт & "poet" \\
\hline
\end{tabular}
word soon) with unrounded lips. Other Russian vowels are:

Four other Russian letters represent vowel sounds in combination with a preceding ysound. The $y$ is clearly heard when the sound(combination) occurs in initial position in a word; in other positions the $\mathrm{y}$ is reduced to a fleeting glide, roughly similar to the

\begin{tabular}{|c|c|c|c|c|}
\hline Я & ya & $\begin{array}{l}\text { Я } \\
\text { ДЯДЯ }\end{array}$ & $\begin{array}{l}{[\mathrm{ya}]} \\
{\left[\mathrm{dv}_{\mathrm{ad}} \mathrm{y}_{\mathrm{a}}\right]}\end{array}$ & $\begin{array}{l}\text { "I" } \\
\text { "uncle" }\end{array}$ \\
\hline e & ye & $\begin{array}{l}\mathrm{eM} \\
\mathrm{B} \in \mathrm{K}\end{array}$ & $\begin{array}{l}{[\mathrm{yem}]} \\
{\left[\mathrm{v}^{\mathrm{y}} \mathrm{ek}\right]}\end{array}$ & $\begin{array}{l}\text { "I eat" } \\
\text { "century" }\end{array}$ \\
\hline$\ddot{e}$ & yo & $\begin{array}{l}\text { ё̈ } \\
\text { лёд }\end{array}$ & $\begin{array}{l}{[\text { yozh }]} \\
{[1 \text { yod }]}\end{array}$ & $\begin{array}{l}\text { "porcupine" } \\
\text { "ice" }\end{array}$ \\
\hline FO & yu & $\begin{array}{l}\text { юГ } \\
\text { бюро }\end{array}$ & $\begin{array}{l}{[\text { yug }]} \\
{[b \text { yuro }]}\end{array}$ & $\begin{array}{l}\text { "South" } \\
\text { "bureau" }\end{array}$ \\
\hline
\end{tabular}
$\mathrm{y}$-glide in the word beauty, as contrasted with booty. Thus,

Two letters, which have no independent sound value, complete this brief inspection of Russian letters and their sounds. They are referred to as "signs" and indicate pronunciation features of preceding letters. One, used infrequently, is called the "hard sign" and occurs only in the interior of a word after a consonant and before a vowel, e.g.

$$
\mathrm{b} \text { b объект "оbject" }
$$

The other is called the "soft sign" and occurs quite frequently. It has the effect of palatalizing or "softening" a preceding consonant. The only effective way for the layman to appreciate the role of the soft sign in pronunciation is to listen to a native speaker(or record) make the following contrasts:

$$
\begin{aligned}
& \text { b b брат "brother" брать "to take" } \\
& \text { занон "law" КОнь "horse, steed" }
\end{aligned}
$$

In a following section all of the above Russian letters are arranged in their proper order.

\section{$\underline{\text { Russian Accent }}$}

The Russian language uses a stress or loudness accent, as does also English; e.g., demonSTRAtion, moNOtony, LAUdatory. Also as in English, the Russian accent is free, that is, it is not limited to a particular syllable but may occur on different syllables in different words. Ordinarily, Russian texts do not indicate the place of stress, except in cases of potential ambiguity, where an acute accent mark would be used, e.g.

$$
\begin{array}{llll}
\text { замо́к } & \text { "lock" } & \text { больша́я } & \text { "big" } \\
\text { за́мон } & \text { "castle" } & \text { бо́льшая } & \text { "bigger" }
\end{array}
$$


The two dots over the Russian letter e indicate both a distinctive sound quality(yo) and also the place of the word accent, e.g.

он берёт "he takes"

Accent markings will not be used in the first part of the manual, since their limited usefulness for a person learning to read Russian hardly compensates for the cluttering effect they have on a running text. In the two sections(Reference, and Vocabulary Help) and in the glossary, where accents are indicated, an acute accent mark denotes the stress, except when the stress falls on the first syllable or is indicated by $\underline{\ddot{e}}$.

\section{RUSSIAN ALPHABET}

The Russian letters discussed in the preceding section are presented below in their correct sequence. The manuscript or handwriting forms of the letters are also added, since Russian scientific texts on occasions employ the manuscript forms for special emphasis.

Since it will be necessary at times to transliterate(i.e. convert into Latin letters), Russian words, the Latin equivalents are also given. Where a Russian word is similar to an English word, there is, of course, no transliteration involved; the standard English spelling would then be used.

\begin{tabular}{|c|c|c|c|c|c|c|c|}
\hline \multicolumn{2}{|c|}{$\begin{array}{l}\text { Russian } \\
\text { Printed } \\
\end{array}$} & $\begin{array}{l}\text { Russian } \\
\text { Manuscript } \\
\end{array}$ & \multicolumn{5}{|c|}{$\begin{array}{l}\text { Latin } \\
\text { Transliteration }\end{array}$} \\
\hline A & a & $d$ & A & a & атом & an120 & "atom" \\
\hline B & 6 & $d$ & B & $\mathrm{b}$ & бланк & OAOLHK & "blank" \\
\hline B & B & $f$ & $\nabla$ & $\nabla$ & вольт & boseonar & "volt" \\
\hline$\Gamma$ & $\Gamma$ & 2 & G & g & ГOHГ & 20 H2 & "gong" \\
\hline I & II & y & D & d & диван & gubat & "sofa" \\
\hline$E$ & e & $e$ & E & e & бензин & OEHzLL & "gasoline" \\
\hline$\ddot{E}$ & $\ddot{e}$ & $\varepsilon$ & Yo & yo & ёлна & e几Ka & "Xmas tree" \\
\hline H & Ж & 30 & $\mathrm{Zh}$ & $\mathrm{zh}$ & жук & xсyK & "beetle" \\
\hline 3 & 3 & $z$ & $\mathrm{Z}$ & $\mathrm{z}$ & звук & 3byk & "sound" \\
\hline и & и & U, & $i$ & $i$ & идеал & ugean & "ideal" \\
\hline Й & $\ddot{\Pi}$ & $U_{10}$ & $\breve{I}$ & İ & MOIL & $\mathrm{NOOZL}$ & "my" \\
\hline $\mathrm{K}$ & K & $\mathcal{K}$ & K & $\mathrm{k}$ & нарта & icarma & "map" \\
\hline JI & $\pi$ & 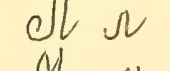 & I & 1 & луна & orjtid & "moon" \\
\hline M & M & CM & M & $\mathrm{m}$ & материал & I shanne/zue & Q"material \\
\hline $\mathrm{H}$ & $\mathrm{H}$ & H & N & n & $\mathrm{HeOH}$ & HeOH & "neon" \\
\hline 0 & 0 & $\sigma$ & 0 & 0 & оператор & onejamo & "operator" \\
\hline$\Pi$ & $\Pi$ & (c) & $P$ & p & процесс & nyoryece & "process" \\
\hline
\end{tabular}

*This is the usage of the Library of Congress. Ideally, the English letter y would, on the basis of pronunciation similarity, make a better representation for Russian but traditional usage has specialized English $\underline{y}$ for Russian $\underline{\underline{E}}$. 


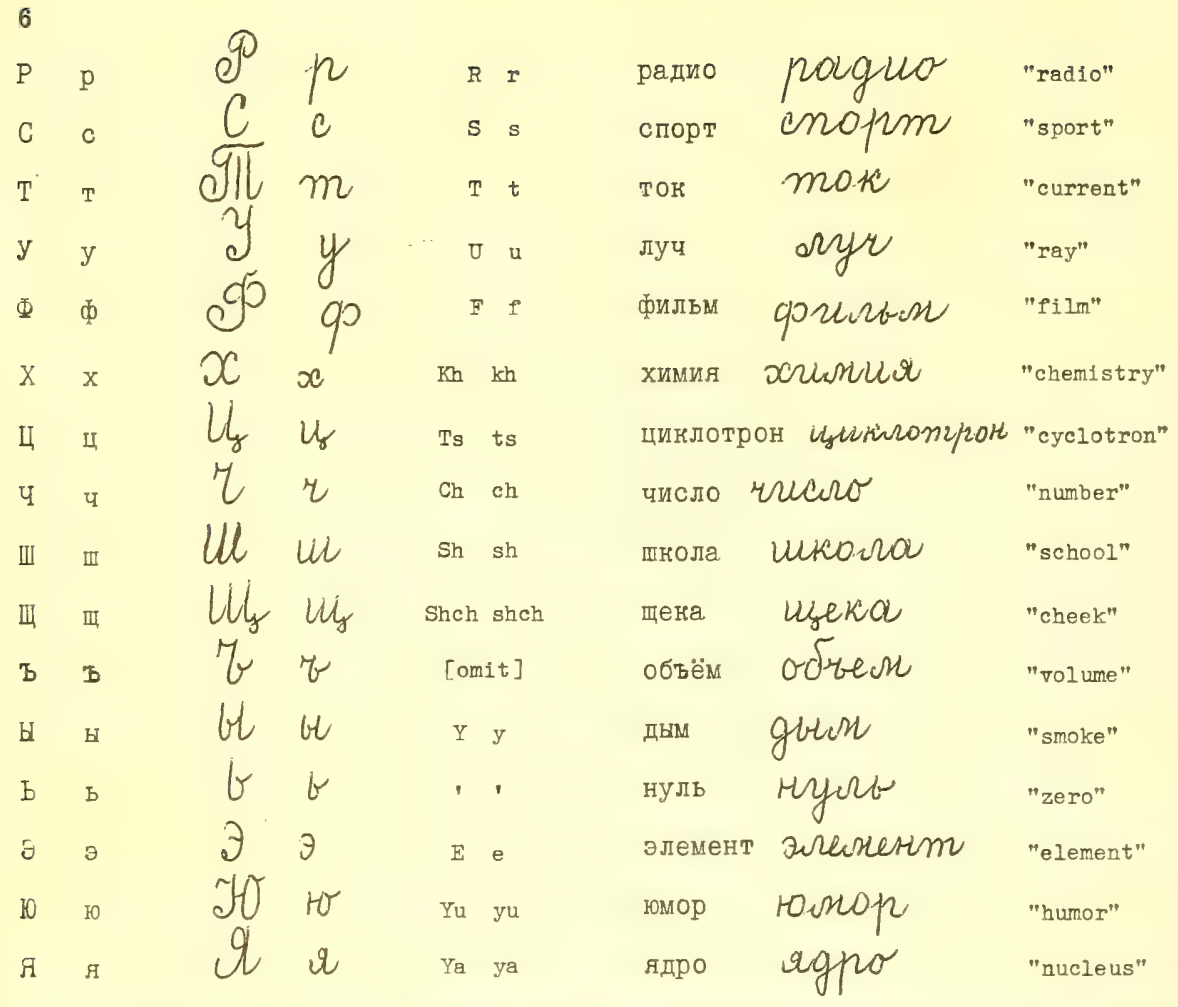

In many Russian texts the two dots for the seventh letter( $\ddot{\mathrm{e}})$ are omitted, a situation which would rarely disturb the Russian reader but one which may confuse the foreigner. Study of the context will usually resolve ambiguous cases. Formerly, the hard sign( $\mathrm{b})$ could be replaced by an apostrophe('), and this usage may be met in the older texts.

Familiarization Practice with Russian Letters

1) What continents, countries or cities are denoted by the following names?

$\begin{array}{ll}\text { Азия } & \text { Кембридж } \\ \text { Америка. } & \text { Куба } \\ \text { Африка } & \text { Јабрадор } \\ \text { Берлин } & \text { Мадрид } \\ \text { Борнео } & \text { Миннеаполис } \\ \text { Вашингтон } & \text { НьюЙорн } \\ \text { Венесуела } & \text { Осло } \\ \text { Глазго } & \text { Россия } \\ \text { цублин } & \text { Сталинград } \\ \text { Европа } & \text { Триест } \\ \text { ненева } & \text { Уругвай } \\ \text { Индия } & \text { Югославия } \\ \text { Ирландия } & \text { Япония }\end{array}$

2) Do you recognize the sciences indicated by the following Russian words?

астрономия
биология
ботаника.
генетина

математина метеорология психология физика 
геограбия

геология

зоОЛОГИЯ
Физиология

Химия

эмбриология

3) Who are these famous scientists ?

Бор
Павлов
Ньютон
Нолио-Кюри
Бойль
Менделеев
Аристотель
Лобачевский

Ламарн

ЛомОНОСОВ

Пастер

Планк

Капица

Лавувье

Эйнштейн

Ферми

4) These Russian words are undoubtedly more familiar to you in their transliterated forms.
водна
спутник
Хрущёв
Кремль
Москва
Молотов
Сталин
Иван
царь
борп
Постоевский
Толстой
Распутин
Ленин

5) Below are tl:e Russian versions of American state names. The distinctive Russian words for "Northern", "Southern" and "Western" will cause no difficulty, once you know that the name for North Dakota will be listed before that of South Dakota.

\begin{tabular}{|c|c|}
\hline Миннесота & Отайо \\
\hline DTa & Виргиния \\
\hline Орегон & Южнал Каролина \\
\hline Вешингтон & Колорадо \\
\hline Айова. & Калифорния \\
\hline Texac & Нью-Мегсико \\
\hline Алабама & Арнанзас \\
\hline Небраска & Јуизиана \\
\hline $\mathrm{M}$ & Флорида \\
\hline Северная Дакота & Индиана \\
\hline Аризона & Мичиган \\
\hline Невада & Иллинойс \\
\hline Южная Данота & Западная Виргиния \\
\hline Монтана & Нью-Йорн \\
\hline Джорджия & Пенсильввния \\
\hline Айдахо & Нью-Гэмпшир \\
\hline Миссури & Массачусетс \\
\hline Онлахома & Род-Айленд \\
\hline Канзас & Ноннентикут \\
\hline Миссисипи & Нью-Джерси \\
\hline Теннесси & Дела вер \\
\hline Кентукки & Мэриленд \\
\hline Виснонсин & Вермонт \\
\hline Северная Каролинв & Вайоминг \\
\hline
\end{tabular}

А Б В ГД Е а б 
Familiarization Practice with Russian Letters(continued)

6) Below is a mixture of Russian words from many fields. They are very similar, in sound and meaning, to English words and so will provide good practice for the student in reading Russian letters.

\begin{tabular}{|c|c|c|}
\hline геометрия & Ливерпуль & әкватор \\
\hline солдат & демократия & Юпитер \\
\hline механин & философия & фильтр \\
\hline Германия & арифметина & лампа \\
\hline метод & Пушкин & тип \\
\hline Шенспир & дебютант & периоп \\
\hline капитан & деб̆лектор & вакуум \\
\hline а кадемик & Стравинский & атмосфера \\
\hline специалист & кондуктор & структура \\
\hline офицер & критик & аппарат \\
\hline орган & Прокофьвев & продукт \\
\hline Черчилль & конденсатор & принцип \\
\hline университет & континент & автор \\
\hline юрист & метр & фонометр \\
\hline фронт & Онеан & спентроснопия \\
\hline поэма & лаборатория & әкономист \\
\hline номедия & кристалл & оптимист \\
\hline гитара & микросноп & суп \\
\hline архитектор & оптимист & характер \\
\hline академия & парабола & донумент \\
\hline пнола & сектор & минимум \\
\hline әнономия & бомба & Hoфूe \\
\hline Кант & симптон & конгресс \\
\hline статистина & фаза & группа \\
\hline оркестр & патриот & профессор \\
\hline Дарвин & орфография & институт \\
\hline Спиноза & парламент & экстрактор \\
\hline материал & параллель & Nacca \\
\hline литература & ротор & студент \\
\hline металл & натод & номпонент \\
\hline реанция & сернвнт & нилометр \\
\hline трагедия & фонстрот & миллион \\
\hline температура & сигнал & Триполи \\
\hline фантор & филология & инверсия \\
\hline Данте & шеф & бюджет \\
\hline анод & центр & авиация \\
\hline Чехов & птат & сумма \\
\hline схема & армия & электрометр \\
\hline Христофор Колумб & өлемент & тост \\
\hline дназ & аналог & Caxapa \\
\hline
\end{tabular}

А БВГДЕ а б в Г д е ё жз й й л мн О п 
Scientific terminology is much the same for both Russian and English, since scientists in both countries use Greek and Latin elements in the formation of new terms, while such terms coined elsewhere are usually adopted in both countries. There is a small number of scientific terms based on Russian roots, e.g.

$$
\text { водород "hydrogen" < вод-а "water" + pод "origin" }
$$

but the overwhelming mass of special terms for scientific phenomena will be recognizable to the American scientist as soon as he acquires some facility in reading Russian letters.

Russian, however, accommodates some letters from Greek and Latin bases in a manner slightly different than the English practice; the result is a superficial difference and one which can be taken care of by a brief consideration of the Russian and English treatment of certain letters.

\begin{tabular}{|c|c|c|c|}
\hline & ENGLISH & & RUSSIAN \\
\hline $\mathrm{au}$ & $\begin{array}{l}\text { author } \\
\text { automobile }\end{array}$ & ab & $\begin{array}{l}\text { автор } \\
\text { автомобиль }\end{array}$ \\
\hline eu & $\begin{array}{l}\text { Europe } \\
\text { rheumatism }\end{array}$ & eв & $\begin{array}{l}\text { Европа } \\
\text { ревматизм }\end{array}$ \\
\hline c & $\begin{array}{l}\text { calory } \\
\text { doctor }\end{array}$ & $\mathrm{K}$ & $\begin{array}{l}\text { налория } \\
\text { понтор }\end{array}$ \\
\hline $\mathrm{ch}$ & $\begin{array}{l}\text { architect } \\
\text { chemistry }\end{array}$ & $\mathrm{x}$ & $\begin{array}{l}\text { архитектор } \\
\text { химия }\end{array}$ \\
\hline h & $\begin{array}{l}\text { humanism } \\
\text { hydrotherapy }\end{array}$ & $\Gamma^{*}$ & $\begin{array}{l}\text { гуманизм } \\
\text { гидротерапия }\end{array}$ \\
\hline ph & $\begin{array}{l}\text { philosophy } \\
\text { photograph }\end{array}$ & Ф & $\begin{array}{l}\text { Ф̆илософй } \\
\text { ф̆отограњ̆ия }\end{array}$ \\
\hline qu & $\begin{array}{l}\text { quadrant } \\
\text { qualification }\end{array}$ & HB B & $\begin{array}{l}\text { квадрант } \\
\text { квалифинация }\end{array}$ \\
\hline th & $\begin{array}{l}\text { mathematics } \\
\text { thermometer }\end{array}$ & $T$ & $\begin{array}{l}\text { математина } \\
\text { термометр }\end{array}$ \\
\hline w & $\begin{array}{l}\text { water-polo } \\
\text { watt }\end{array}$ & B & $\begin{array}{l}\text { ватерполо } \\
\text { ватт }\end{array}$ \\
\hline y & $\begin{array}{l}\text { pyrometer } \\
\text { type }\end{array}$ & и & $\begin{array}{l}\text { пирометр } \\
\text { тип }\end{array}$ \\
\hline
\end{tabular}

* In some words of foreign origin Russian replaces the letter $\underline{\mathrm{h}}$ by Russian $\underline{\mathrm{x}}$, e.g. xонkеĭ "hockey, xоппер" "hopper". 
To a speaker of English, the principal distinguishing characteristics of Russian would seem to be:

1. A system of six grammatical cases for nouns, pronouns, adjectives and numbers.

2. The phenomenon of gender(masculine, feminine and neuter) for nouns and adjectives.

3. Great freedom of word order, made possible by the complex case system.

4. Lack of the definite("the") or indefinite("a, an") article.

5. Verbal system employing only two simple tenses: past and non-past ("present").

6. Verbal aspect: the choice between two Russian verbs, distinguished by a nuance of completion, for every one English verb.

7. Reflexive verbs: verb forms with a special suffix which adds passive, reflexive, reciprocal or no extra meaning, depending on the particular verb.

8. Six verbals: four participles(verbal adjectives) and two gerunds(verbal adverbs).

9. Lack of present forms("is, are") of the verb "to be".

10. Double negatives with maintenance of negation.

Grammatical Terminology

Traditional grammatical terminology will be employed in this manual, not because it has functional relevance, but simply because it will be found in other texts and dictionaries which a learner will have occasion to consult. One should use these ancient terms merely as labels for identifying grammatical categories peculiar to Russian, being careful, however, not to regard grammatical phenomena in Russian and English as comparable only because of a shared tradition of terminology.

\section{CASE SYSTEM}

There are six grammatical cases in Russian and their traditional names are: Nominative(N), Accusative(A), Genitive(G), Dative(D), Prepositional(P) and Instrumental (I). The differences between the elaborate case system of Russian and the English system of two cases(possessive and non-possessive) may be demonstrated most readily by comparing the treatment in each language of four nouns in various simple sentence types.

The table is there.

1) The lake is there.

The map is there.

The door is there.

2) I see the table/lake/map/door.

3) I know the table's/lake's/map's /door's size.

4) $\mathrm{He}$ is walking toward the table /lake/map/door.

5) That's on the table/lake/map/door.

6) That's behind the table/lake /map/door.
Стол там.

Озеро там.

Карта там.

Iверь там.

Я вижу стол/озеро/карту/дверь.

Я знаю размер стола/озера/нарты /двери.

Он идёт н столу /озеру/нарте/пвери.

छто на столе/озере/карте/двери.

бто за столом/озером /нартой/дверью. 
To make the contrast even more stark, the two form(table : table's) variation of English could be reduced to one by using "of the table" instead of the possessive form "table's". The Russian forms may now be arranged and identified as to case in the following manner:

$\begin{array}{lllll}\mathrm{N} & \text { стол } & \text { озеро } & \text { нарта } & \text { Дверь } \\ \mathrm{A} & \text { стол } & \text { озеро } & \text { нарту } & \text { Дверь } \\ \mathrm{G} & \text { стола } & \text { озера } & \text { нарть } & \text { Двери } \\ \mathrm{D} & \text { столу } & \text { озеру } & \text { нарте } & \text { Двери } \\ \mathrm{P} & \text { столе } & \text { озере } & \text { нарте } & \text { Двери } \\ \mathrm{I} & \text { столом } & \text { озером } & \text { нартой } & \text { дверью }\end{array}$

Russian has, like English, a plural(pl.) number and so presents further distinctions for the plurals of these six cases. Thus,

$\begin{array}{lllll}\text { N } & \text { столы } & \text { озёра } & \text { нарты } & \text { двери } \\ \text { A } & \text { столы } & \text { озёра } & \text { нарты } & \text { двери } \\ \text { G } & \text { столов } & \text { озёр } & \text { нарт } & \text { дверей } \\ \text { D } & \text { столам } & \text { озёрам } & \text { нартам } & \text { дверям } \\ \text { P } & \text { столах } & \text { озёрах } & \text { нартах } & \text { дверлх } \\ \text { I } & \text { столами } & \text { озёрами } & \text { нартами } & \text { дверями }\end{array}$

Closer inspection of this welter of forms will show a considerable amount of overlapping. In the singular, for example, this situation is this:

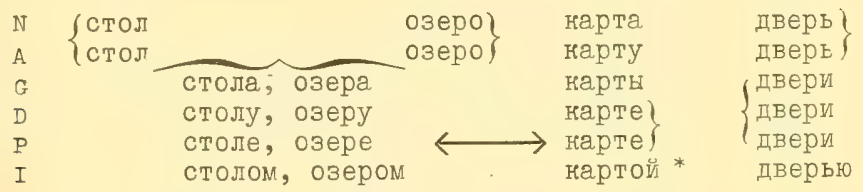

The plural is much less complex, since "ending" distinctions disappear entirely for

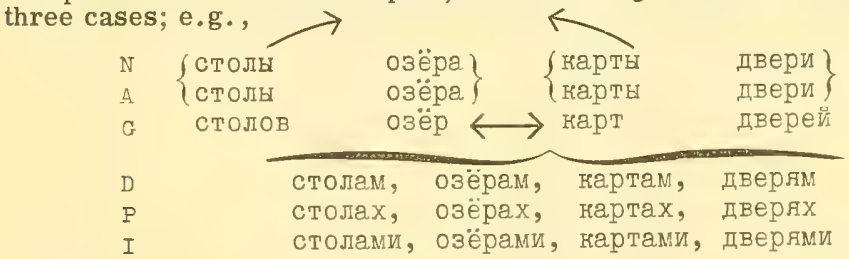

\section{GENDER}

The four sets of nouns under consideration are distinguished by different "endings"; Looking only at the nominative singular(N-sg.) forms, e.g.

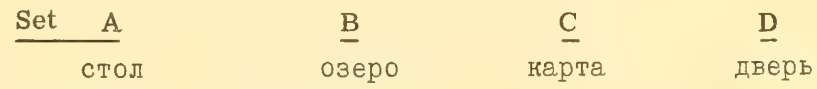

one could say that the distinctive difference for set $B$ is the ending -0 , for set $C$ the ending -a and the ending $\underline{b}$ for set $D$. Set $A$ is distinguished by not ending in a vowel, in fact, by having no ending(Zero ending); this basic form has, characteristically, a consonant letter in final position.

If one considers the meanings assigned to Russian words, it becomes obvious that

*A longer "ending" is optionally (and infrequently) used in this category, e.g. картою. 
most words designating beings of male gender fall into set $\mathrm{A}$, while those which indicate female beings go into set $C$. For example,

\begin{tabular}{llll} 
Set A & & \multicolumn{2}{c}{ Set C } \\
студент & student & ступентн & girl student, coed \\
отец & father & бабушна & grandmother \\
брат & brother & сестра & sister \\
муж & husband & жена & wife
\end{tabular}

It is useful to refer to the nouns of set A as "masculine (masc.), while the nouns of set C may be called "feminine"(fem.). Since set B has, as a general rule, no terms denoting living beings, its nouns receive the name "neuter"(neut.). These gender references are helpful, but they do have certain limitations; there is, for example, nothing specifically "masculine" about стол , "table" nor anything "feminine" about Hapтa." "map".

Furthermore, the nouns in set D(e.g. Дверь , "door") are also called "feminine", because they are modified by the same form of the adjective used for nouns of set $C$; this will be shown in a following section on adjectives.

Animate and Inanimate

In the accusative plural for all nouns and the accusative singular for masculine nouns a form distinction is made between animate and inanimate entities. This does not mean that a new form is created, since a form identical to that of the genitive is used for the animate beings. Note the distinction in the accusative forms below; the sentence types used mean: I) Where is the ?/Where are the here./There are no here. ?; 2) I see ; 3) There is no

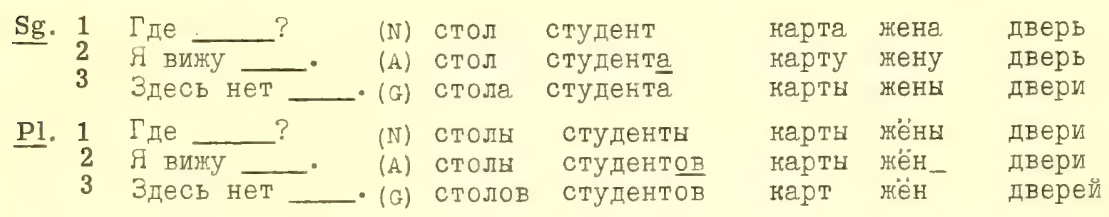

AT THIS POINT THE WHOLE RANGE OF VARIATIONS IN NOUN DECLENSIONS CAN BE CONSIDERED BY TURNING TO SECTION II (PARADIGMS) OF THE MANUAL. STUDY THE NOUN FORMS AND NOTE ANY FEATURES NOT COVERED IN THE ANALYSIS OF THE PAST FEW PAGES.

\section{Gender Markers in N-sg. Forms}

An inspection of the noun declensions has undoubtedly indicated that the "soft sign" $\left({ }_{b}\right)$ is not characteristic only of nouns like дверь, since a number of masculine nouns have final $\mathrm{b}$ in the $\mathrm{N}-\mathrm{sg}$. case. The other $\mathrm{sg}$. case forms of such nouns serve to establish the gender, e.g. G-sg. норабля : пвери. Tо sum up, in the N-sg.,

masc. nouns have Zero ending(final consonant): стол, студент, гений or $-\mathrm{b}:$ корабль, автомобиль

neut. nouns end in the vowel letter -o: or $-\mathrm{e}$ :

fem. nouns end in the vowel letter -a : or - я : or -5 : озеро, место, окно поле, здание, ружьё карта, черта, жена неделя, линия, земля Дверь, вещь, возможность 


\section{VARIATIONS IN CASE ENDINGS}

Inspection of the various noun declensions may have raised some doubt on the part of the beginner about the exactness of the previous analysis of case endings. However, the variations exemplified in Section II will be readily understood if one accepts the following pattern of alternations:

$$
\begin{aligned}
& -0 /-5,-i \frac{1}{1} \\
& -a /-9 \\
& -0 /-e,-\ddot{e} \\
& -y /-10 \\
& -0 /-11
\end{aligned}
$$

\begin{tabular}{|c|c|c|c|c|}
\hline \multirow[t]{6}{*}{ Sg. } & $\mathrm{N}$ & стол & норабл - Б & случа-й \\
\hline & A & стол & нора.бл-ь & случа-й \\
\hline & G & стол-а. & норабл-я & случа-я \\
\hline & D & стол-у & корабл-ю & случа-ю \\
\hline & $P$ & (стол-е & норабл-е & случа-е) \\
\hline & I & Стол-OM & норабл-ём & случа-ем \\
\hline \multirow[t]{6}{*}{ Pl. } & $\mathrm{N}$ & стол-ы & нораблли & случа-и \\
\hline & A & стол-в & корабл-и & случа-и \\
\hline & G & СТОЛ-ОВ & (норабл-ей) & случа-ев \\
\hline & D & стол-ам & норабл-ям & случа-ям \\
\hline & $\mathrm{P}$ & стол-ах & норабл-ях & случа-ях \\
\hline & T & стол-ами & корабл-ями & случа-дми \\
\hline
\end{tabular}

[0 represents Zero ending, that is, any final consonant except-h̆

Consider the case endings of three masc. nouns and notice how the ending variations are to a great extent predictable from the above pattern.

The same catalyst may be applied to neuter and feminine( -a/f type) nouns and a similar simplification will result.

P-sg. and D-sg. (fem.) Ending -e

This ending is out of the pattern of alternations, being regularly -e for nouns of all genders in the P-sg; the same ending characterizes the D-sg. of fem. nouns. When preceded by the vowel $\underline{\underline{n}}$, the same vowel is used for the ending, replacing - $\underline{\mathrm{e}}$, e.g.

$\begin{array}{lccccc}\text { D } & (\text { стол-y } & (\text { случа }-ю) & (\text { гени-ю } & (\text { озер-у } & (\text { здани-ю) номнат-е лини-и } \\ \mathrm{P} & \text { стол-е } & \text { случа-е } & \text { гени-и } & \text { озер-е } & \text { здани-и номнат-е лини-й }\end{array}$

Observations about Plural Endings

As previously pointed out, there are no specific gender endings for three cases of the plural. If the catalyst is applied to the limited variation of endings in these three cases, it will be seen that the simple alternation $\mathrm{a} / \mathrm{r}$ is involved. Thus,

$\begin{array}{lllllll}\text { D } & \text { стол-ам } & \text { норабл-ям } & \text { озёр-ам } & \text { пол-ям } & \text { карт-ам } & \text { лини-ям } \\ \text { P } & \text { стол-ах } & \text { норабл-ях } & \text { озёр-ах } & \text { пол-ях } & \text { нарт-ах } & \text { лини-ях } \\ \text { I } & \text { стол-ами } & \text { порабл-ями } & \text { озёр-ами } & \text { пол-ями } & \text { гарт-ами } & \text { лини-ями двер-ями }\end{array}$

Consider now the NA cases in the plural:

$\begin{array}{llllllll}\mathbb{N} & \text { стол-ы } & \text { норабл-и } & \text { озёр-а } & \text { пол-я } & \text { нарт-ш } & \text { лини-и } & \text { Пвер-и } \\ \text { A } & \text { стол-ы } & \text { норабл-И } & \text { озёр-а } & \text { пол-я } & \text { нарт-ш } & \text { лини-л } & \text { двер-и }\end{array}$


There is not much variation here; it may be said that neut. nouns end in $-a /-r$, while masc. and fem. have the ending alternation $-\mathrm{H} / \mathrm{h}$. If animate nouns are involved, the A-pl. forms will be identical with thuse of the G-pl., e.g. N-pl. жён-s, A-pl. жён, G-pl. жён.

The range of $\mathrm{G}-\mathrm{pl}$. endings may be exemplified as follows:

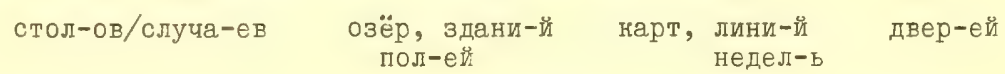

The typical masc. G-pl. ending is $-\underline{O B} /-\underline{e B}$, while neut. and fem. nouns have Zero ending (no ending). Neut. and fem. nouns also occur with the ending $-\underline{\underline{b}}$ or $-\underline{\underline{L}}^{*}$ and some nouns in all genders have the ending - eh̆.

\section{Some Special Situations for Masc. Nouns}

A limited number of masc. nouns have the ending $-\underline{y}$ in the P-sg. after the prepositions $\underline{B}$ and $\underline{\mathrm{HQ}}$.

$$
\begin{array}{lll}
\text { год "уеаr" } & \text { о годе } \\
\text { нрай "border" } & \text { о трае } & \text { в году } \\
\text { берег "shore" } & \text { о береге }
\end{array}
$$

Certain masc. nouns have an accented a-ending in the $\mathrm{N}$ and $\mathrm{A}$ (inanimate) plural, instead of the usual $\underline{\underline{H}}(/ / \mathrm{n})$.

N A

понтор "doctor"
город "city"
учитель "teacher"

$\begin{array}{lll}\text { донтора } & \text { понторов } & \text { покторов } \\ \text { города } & \text { города } & \text { городов } \\ \text { учителя } & \text { уиителей } & \text { учителеи }\end{array}$

учителя учителей учителеу

A few masc. nouns have the ending $\underline{b A}$ in the $\mathrm{N}$ and $\mathrm{A}$ (inanimate) of the plural.

$$
\begin{array}{lllll} 
& & \text { N } & \text { A } & \text { G } \\
\text { стул } & \text { "chair" } & \text { стулья } & \text { стулья } & \text { стульев } \\
\text { брат } & \text { "brother" } & \text { братья } & \text { братьев } & \text { братьев }
\end{array}
$$

A number of masc. nouns which denote the young of animals are characterized by

\begin{tabular}{|c|c|c|c|c|c|c|c|}
\hline & $\underset{\text { телёнон }}{\stackrel{N}{N}}$ & "cale" & $\begin{array}{c}\text { A } \\
\text { телёнка }\end{array}$ & $\begin{array}{c}G \\
\text { телёнка }\end{array}$ & $\begin{array}{c}\text { D } \\
\text { телённу }\end{array}$ & $\frac{\text { P }}{\text { телёнке }}$ & $\stackrel{\text { I }}{\text { телёнком }}$ \\
\hline Pl. & телята & & телят & телят & телятам & телятах & телятами \\
\hline
\end{tabular}
-ёнон/ОНОК in the singular but by -ята/-а.та in the plural forms; the AG-pl. forms have zero ending.

\section{ADJECTIVES}

A division according to gender results in three sets of adjective forms in the singular, while in the plural gender distinctions are ignored and there is only one set of plural adjective forms, e.g.
Set A
B
новый стол
новое слово
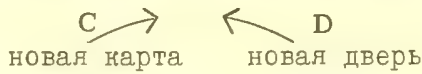

Study of the adjective forms in Section II (PARADIGMS) will reveal the following basic pattern:

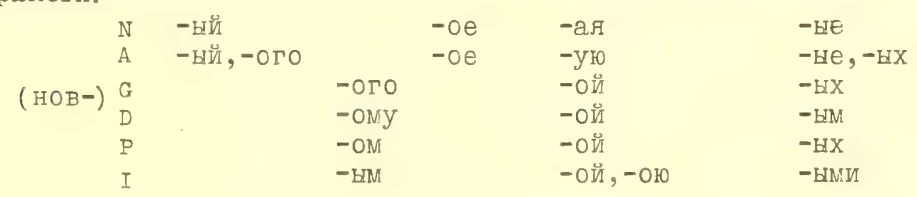

*These could also be considered to represent zero endings, if one assumes that the letter $g=\mathrm{b} / \ddot{h}+\mathrm{a}$ and that $\mathrm{e}=\mathrm{b} / \ddot{\Pi}+0$. Thus, $N-s g$. Hege $-\mathrm{f}$ could theoretically be written недель-a a form which would have regularly G-pl. недель, while 3 даний would be the

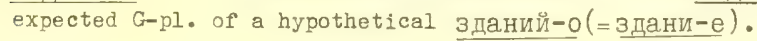


Forms for the adjective послепн- may be accommodated into this pattern by accepting alternations similar to those set up for noun variations, e. $g$.

$$
\begin{aligned}
& a / \text { я } \\
& 0 / \mathrm{e} \\
& y / 10 \\
& \mathrm{~b} / \text { и }
\end{aligned}
$$

Two minor variations have not been taken into account as yet. They are:

1) In cases $N$ and $A$ (inanimate) of the masc. sg., the ending-ö occurs for some adjectives. This ending always bears the accent, while-ŭ̃ never does; e.g., просто́й но́внй просто́е но́вое проста́л но́вая : прости́е но́вые

2) Some adjectives, which have - $\underline{-}$ - in pre-ending position for most forms, have special short endings in NA-pl. and NA-sg.(for neut. and fem.); e.g.,

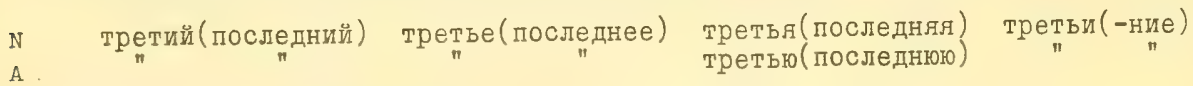

SUMMARY OF ADJECTIVE ENDINGS

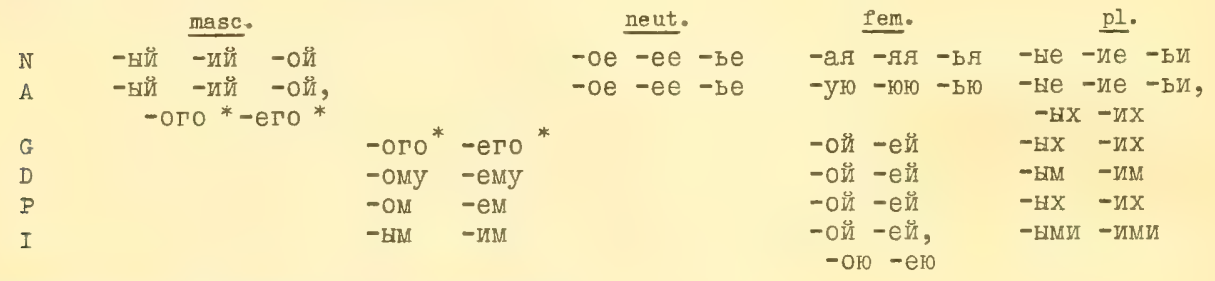

Restrictions on Consonant-Vowel Groupings

The vocalic alternations which form such neat patterns in the matter of noun and adjective endings are disturbed by a few restrictions on the grouping of consonant and vowel letters. The restrictions are these:

1) the letters

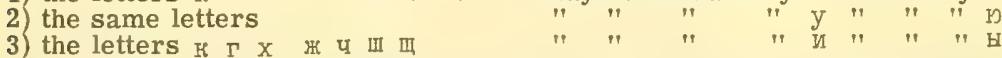

3) the letters

5) the letters $\nVdash_{\text {บ }}$ III II I may be followed by o only when it bears the accent (ó);

\begin{tabular}{|c|c|c|c|c|c|c|c|}
\hline русенс. & "a Russian" & русстал & "a Russian" & Haceromoe & "insect" & русенй & "Russian \\
\hline учёный & "scientist" & кривая & "curve" & животное & "animal" & даннше & "data" \\
\hline портной & "tailor" & мостовая & "parement" & будущее " & "the future" & кривне & "curves" \\
\hline
\end{tabular}

otherwise, the vowel e occurs. For example, мyж "husband", I-sg. мýmeм

нож "knife", I-sg. ножо́м

Adjectives with Noun Meaning

A number of Russian words which are adjectival in form may occur alone with a noun meaning; for example,

Many Russian family names have adjectival endings, particularly those ending in -ский, e.g.

\footnotetext{
Чайновский; музнна Чайновсного

"Tchaikovsky; the music of Tchaikovsky"
}

\footnotetext{
*The letter $\Gamma$ in these adjectival endings represents the sound $\square$, normally indicated by the Russian letter B. This is one of the few irregularities of the Russian spelling system.
} 
Masc. Nouns in Fem. Declension

Some nouns are masc. in gender but are declined like fem. nouns; these nouns a re masc. in that they denote male beings and are modified by the masc. forms of the adjective. For example,

$\begin{array}{llll}\text { мужчина } & \text { "men" } & \text { большой мужчина } & \text { "a big man" } \\ \text { дядя } & \text { "uncle" } & \text { старнй дядя } & \text { "an old uncle" } \\ \text { слуга } & \text { "servant" } & \text { верний слуга } & \text { "a faithful servant" }\end{array}$

\section{Indeclinable Nouns}

A number of nouns borrowed into Russian have never been accommodated within the case system; they are "indeclinable", that is, they do not change or add endings, no matter what the linguistic environment. Neuter gender has been assigned to most of these nouns. A few examples are:

$\begin{array}{llll}\text { метро } & \text { "subway" } & \text { мы едем на метро } & \text { "we 're going by subway" } \\ \text { резюме } & \text { "resume" } & \text { из нратного peзюме } & \text { "from a short resume" } \\ \text { нофе (masc.) } & \text { "coffee" } & \text { чёрный коळ̆е } & \text { "black coffee" }\end{array}$

\section{USE OF CASES}

Case selection for nouns and adjectives is, in general, automatic after the unchanging forms called "prepositions". In most textual situations one simply locates a preposition and then looks for adjectives and nouns in a determined case. Thus, if the preposition(prep.) после "after" appears, one should look for forms in the genitive case, e.g. после нового урока "after the new lesson". The prepositional case is used only after prepositions and so is immediately determined as to usage and interpretation.

Below in tabular form are those prepositions which are frequently used; this arrangement indicates the cases associated with particular prepositions. In a later section(VOCABULARY HELP) a complete list of prepositions is presented, and the meanings of the prepositions below may be quickly determined by a glance at the longer listing.

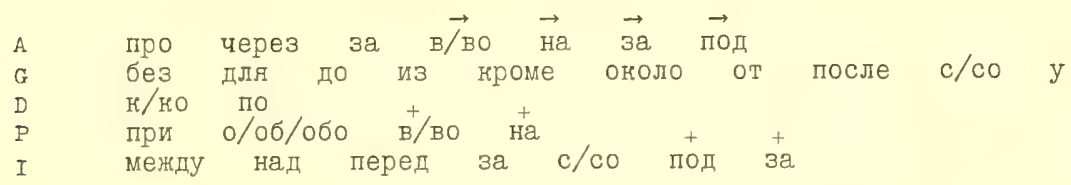

\section{Prepositions - Motion vs. Rest}

Though most prepositions occur in phrases where the case of the constituent noun or adjective is determined by the preposition itself, there are four prepositions which have two case possibilities, with the choice being made on the basis of meaning. If the prep. serves to channel motion from verb to noun, then the case selection will be accusative; if rest or location is intended, the prepositional case is used by two of the prepositions, while two employ the instrumental case.

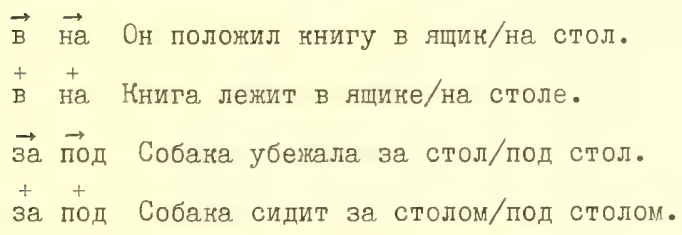

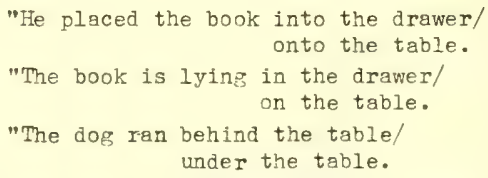




\section{USE OF CASES (continued)}

With the exception of prepositional phrases the following brief survey covers the chief case usages of nouns and adjectives.

\section{NOMINATIVE}

1) In simple questions or statements:

2) In both terms of equational sentences (e.g. $A=B)$ :

3) As subject of a verb:

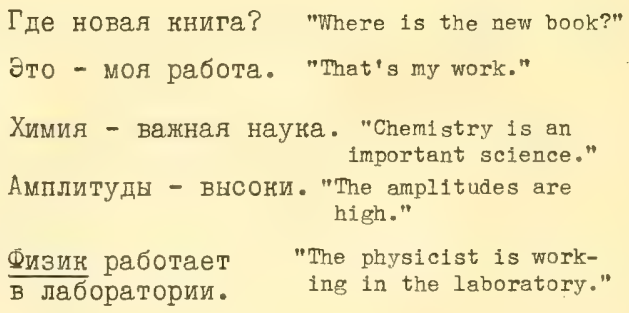

\section{ACCUSATIVE}

1) As the object of most Russian verbs:

Он слупает лекцию. Науна открыла новые источники энергии.

2) In certain expressions denoting duration Пациент отдыхал of time:

\section{GENITIVE}

1) Usually after a negated verb:

2) After нет "there is not/there are not"

3) In situations where English would use a possessive or the preposition "of": всю зиму.

Яаботал нруглый

ГОД.
Нет полезного результата.

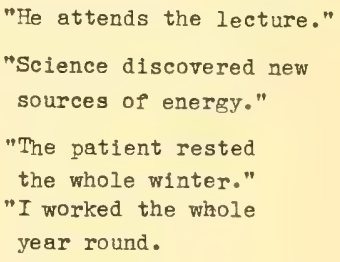

Раньше учённе не читали "Formerly scientists руссних журналов. did not read Russian journals."

"There is no useful result."

свойства того растения "the properties человек большого таланта of that plant"

"a person of great talent"

4) After words such as много "many, much", мало "little, a few", сколько "how much", etc.:
5) After verbs to denote "some" or "a portion of":

6) After certain verbs:
Дайте мне водн: "Give me some water!"

Она боялась энзамена. "She was afraid 
USE OF CASES (continued)

DATIVE

1) Indirect object:

Проф̆ессор дал статью "The professor gave the своему студенту. article to his student."

2) Subject of impersonal expressions: Монно мне pаботать "Can I[Is it possible здесь?

3) After certain verbs:

Ассистент помогает профеcсору.

"The assistant helps the professor."

\section{PREPOSITIONAL}

(This case is used only after the prepositions: при, в, на, о/об/обо, по.) INSTRUMENTAL

1) To denote means or instrument: Я пишу нарандашом. "I am writing with[by

2) Similarly, to denote agent:

Јенция была прочитана "The lecture was американским учёным . given[read] by an American scientist."

3) As a case of specification or reference: шириной "in width, as to width" толщиной "in thickness" плино "in length"

4) Often with future and past tense forms of the verb "to be":

$$
\begin{aligned}
& \text { Mой сын будет вpaчом. "My son will be a } \\
& \text { Он был солдатом." } \\
& \text { "He was a soldier." }
\end{aligned}
$$

5) After special verbs:

Они занимаются "They are carrying on
важными исследованиями. important investi-
gations."

Separation Vowel o/e

Certain consonant letters, which may occur in clusters before a vowel ending, e.g. ОКно "window", are separated by the vowel letter oo er before zero ending(no ending), e.g. G-pl. 아으. The letter $b$ ("soft sign") in such clusters is replaced by the e-vowel, for example, N-sg. письмо "letter", G-pl. писем. This vowel insertion may be noticed in the following categorie $\mathbf{s :}$

1) N-sg. of masculine nouns:

нусок
пень
лёд
G-sg. куска
дня
льда
D-sg. куску
дню0
льду
"piece"
"day"
"ice"

2) G-pl. of fem. and neut. nouns:

$\begin{array}{lll}\text { ошибон } & \mathrm{N}-\mathrm{Sg} \cdot & \text { ошибна } \\ \text { нолец } & \text { нольцо } \\ \text { деревень } & \text { деревня }\end{array}$

$$
\begin{aligned}
& \text { "mistake" } \\
& \text { "ring" } \\
& \text { "village" }
\end{aligned}
$$

3) Masc. short forms of some adjectives

$$
\text { (see following section): }
$$

$\begin{array}{llll}\text { полон } & : & \text { Полный } & \text { "full" } \\ \text { виден } & : & \text { видный } \\ \text { доволен } & : & \text { довольный "satisfied" }\end{array}$




\section{SHORT FORMS OF ADJECTIVES}

Many Russian adjectives have special short forms, four in number, which occur only in the nominative case and only in a predicative("the paper is white") usage. Thus,

\section{Regular Forms}

$$
\begin{array}{llll}
\text { бел-ый } & \text { бел-ое } & \text { бел-ая } & \text { бел-ые } \\
\text { чист-ый } & \text { чист-ое } & \text { чист-ая } & \text { чист-не }
\end{array}
$$

Some examples are:

\section{Short Forms}

$\begin{array}{llll}\text { бел } & \text { бел-о } & \text { бел-а } & \text { бел-ы } \\ \text { чист } & \text { чист-о } & \text { чист-а } & \text { чист-ы }\end{array}$

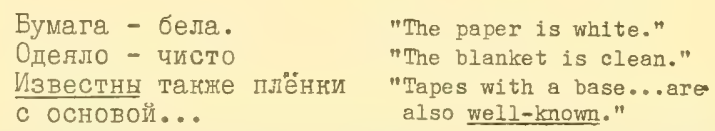

These short forms never modify a noun. The freedom of Russian word-order may result in the appearance of the predicative short form ahead of the noun, as in the last example above, but the English translation must separate the noun and the short form adjective by a form of the verb "to be"(i.e. is/are, was/were, will be).

The formation of the short form adjective is quite clear from the examples above. However, for some adjectives the normal formation of the masc. short form( бел< бел-нй) would leave a final cluster of consonants unacceptable to the Russian speaker(see page 18). Such clusters are resolved by the insertion of the vowel o or e, e.g.

\begin{tabular}{|c|c|c|c|c|c|}
\hline$H-H И ̆$ & "red" & нрасен & грасн-о & грасн-а & нрасн-ы \\
\hline KOD & "short" & нороток & нороти-о & норотн-а & норотк-и \\
\hline умН-ЫЙ & "clever" & YMéH & умн -0 & YMH - & умн-ы \\
\hline
\end{tabular}

Adjectives ending in -ский do not have short forms, though the adverb in - Сนи might seem to the beginner to be a short form of the plural number(see page 31 )

\section{PRONOUNS}

\begin{tabular}{|c|c|c|c|c|c|c|c|c|}
\hline & $\begin{array}{l}\text { "I, } \\
\text { me" }\end{array}$ & "you" & $\begin{array}{l}\text { "he,him, "it" } \\
\text { it" }\end{array}$ & $\begin{array}{l}\text { "she, her, } \\
1 t "\end{array}$ & $\begin{array}{l}\text { "we, } \\
\text { us" }\end{array}$ & "you" & $\begin{array}{l}\text { "they, } \\
\text { them" }\end{array}$ & "-self" \\
\hline $\mathrm{N}$ & Я & TH & $\mathrm{OH} \quad \mathrm{OHO}$ & она & $\mathrm{MB}$ & $\mathrm{BH}$ & они & --- \\
\hline A & меня & тебя & ето/нето & eё/Heё & Hac & $\mathrm{BaC}$ & их/них & себя \\
\hline G & меня & тебя & его/него & $e \ddot{e} /$ Hë̈̈ & нас & $\mathrm{BaC}$ & иx/Hиx & себя \\
\hline D & MHe & тебе & ему/нему & ей/ней & нам & вам & им/ниМ & себе \\
\hline$P$ & мHe & тебе & нём & ней & нас & Bac & них & себе \\
\hline I & $\begin{array}{l}\text { Mной, } \\
\text { MНОю }\end{array}$ & $\begin{array}{c}\text { тобой, } \\
\text { тобою }\end{array}$ & ИМ/ним & $\begin{array}{l}\text { ей/ней, } \\
\text { ею/нею }\end{array}$ & нами & вами & иМи/ними & $\begin{array}{r}\text { собой, } \\
\text { собою }\end{array}$ \\
\hline
\end{tabular}

The pronoun variants with initial $\underline{H}$ always-occur after prepositions, e.g.

$$
\begin{array}{cl}
\text { без нето } & \text { "without him" } \\
\text { с ними } & \text { "with them" } \\
\text { Мы говорили о ней. } & \text { "We were talking about her." }
\end{array}
$$

Since the prepositional case is used only with prepositions, as in the last example above, it has only a pronoun form with $\underline{H}$.

There are three unchanging possessive words: $\underline{\text { ero }}$ "his",its", $\underline{\mathrm{e} e \mathrm{e}}$ "hers, its" and $\underline{\mathrm{nx}}$ "their", which should not be confused with similar-appearing case forms of the pronouns. Some contrasts are:

$$
\begin{array}{ll}
\text { в его доме "in his house" } \\
\text { в нём }
\end{array}
$$




$\begin{array}{ll}\text { без их нниг } & \text { "without their books" } \\ \text { без них } & \text { "without them" } \\ \text { Я ёе вижу. } & \text { "I see her." } \\ \text { Я вижу её нниги. "I see her books." }\end{array}$

The forms: $c$ бя, etc. refer back to the subject and are to be translated "oneself, myself, himself, herself, itself, ourselves, yourselves, themselves", depending on the translation of the subject word. For example,

Она взнла на себл ответственность. Мн поставили себе эту цель.

\section{You and You}

Russian has two words for "you": $\underline{\mathrm{TH}}$ and $\mathrm{BH}$ in the nominative case. The pronoun designates one person with whom the speaker or writer shares an informal relationship (member of family, child, friend, colleague, etc.), while BH denotes either 1) two or more persons, or 2) one person with whom the speaker is on more formal terms(stranger, amployer, visitor, etc.). The same distinction is reflected in the two sets of forms for the pronominal adjective: "your", TBoî (informal) and BaII (formal).

\section{COMPARISON}

Things or actions may be compared or contrasted by the use of comparative or superlative forms of adjectives. Comparative forms are made by the use of бoJee "more" or менеe "less" before a regular adjective form; the basic adjective forms change in case and number, but the forms более/менеedo not. For example,

более глубоная река
менее дорогой инструмент
на более быстром коне

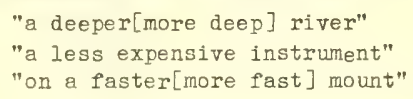

The linking word "than" is expressed by uem, e.g.

$$
\text { Миссисипи - более глубоная рена, чем Миссури. "The Mississippi is a deeper }
$$

\section{Superlatives}

The superlative degree is achieved by the use of the appropriate form of the adjective самый before the basic adjective; e.g. ,

$$
\begin{array}{ll}
\text { самая Глубоная рена } & \text { "the deepest[most deep] river" } \\
\text { на самом бьстром коне } & \text { "on the fastest[most fast] mount" }
\end{array}
$$

\section{Adverbs of Comparison}

It is possible to form comparative adverbs from a large number of adjectives. As adverbs, these forms do not change for number(i.e. sg./pl.) or gender; in usage they appear only in the predicate(e.g., he is bigger, he talks more than he works, etc.). For many words the transition from adjective to adverb of comparison is accomplished simply by adding -ee $(-\underline{\mathrm{e} i})$ to the adjective base; e.g.,

$$
\begin{array}{llll}
\text { бнстр-ый } & \text { "fast" } & \text { быстр-еe } & \text { "faster" } \\
\text { бел-ый } & \text { "white" } & \text { бел-еe } & \text { "whiter" } \\
\text { интересн-ыЙ } & \text { "interesting" } & \text { интерес--ee } & \text { "more interesting" }
\end{array}
$$


Certain adjectives are converted by the addition of a final $\underline{\mathrm{e}}$ to an altered base, e.g.

\begin{tabular}{|c|c|}
\hline Кий & "deep" \\
\hline & "dear" \\
\hline
\end{tabular}

Frequently used comparative adverbs of this latter type are given in a reference listing (REFERENCE)

With comparative adverbs of these two types "than" is expressed either by yeM or simply by construing the comparative item in the genitive case; e.g.,

Волга глубже всех других рен в Европе.

Волга глубже чем все другие рени в Европе. "The Volga is deeper than all the
other rivers in Europe."

\section{NUMBERS}

Fortunately for the student of Scientific Russian, numbers will usually be encountered as symbols $(1,2,3$, etc. ) rather than as words. This is indeed fortunate, since the declension pattern of numbers in Russian is decidedly a mixed one. All of the forms will be given in Section II(PARADIGMS), but the following groupings may be presented here:

1) Number 1 has a complete adjectival declension.

2) Numbers 2,3 and 4 have similar treatment to each other.

3) Numbers 5-10, 11-19,20,30,50,60,70 and 80 are declined like the noun дверь.

4) Numbers 40,90 and 100 are similar in their limited variations.

5) Numbers 200, 300 and 400 are alike.

6) Numbers $500,600,700,800$ and 900 are alike.

7) Numbers 1,000 and 1,000,000 are declined as regular nouns, fem. and masc. respectively.

\section{Differences in Symbolism}

Though English and Russian both use the same "Arabic" symbols(1,2,3, etc.), there is a slight difference in the use of the comma and the decimal point: the usage of one language is the reverse of the other; e.g.,

$$
\begin{aligned}
& \text { English } 3,000=\text { Russian } 3.000 \\
& 1.50 \quad 1,50
\end{aligned}
$$

Case Usage after Numbers

In cases GDPI nouns and adjectives have the same forms after numbers as they would have without the presence of numbers .

When the number is used in the $\mathrm{N}$ or $\mathrm{A}$ case, dependent nouns and adjectives are put in the G-pl. after all numbers above 5, e.g.

$$
\text { пять новых инструментов "five new instruments" }
$$

After 2, 3 or 4 the noun occurs in the G-sg., though the adjective may be either in the N-pl. or the G-pl.; e.g.,

$\begin{array}{ll}\text { три новнх инструмента. } & \text { "three new instruments" } \\ \text { две новые статьи } & \text { "two new articles" }\end{array}$

In compound numbers the last element(2/3/4:5/above) determines this case selection.

In the NA cases there are two forms for 2 and also for the word "both"; два, оба are used with nouns of masc. or neut. gender, Две,

$$
\begin{aligned}
& \text { два/оба вида "two/both types" пве/обе картн "two/both maps" } \\
& \text { два/оба здания "two/both buildings" }
\end{aligned}
$$




\section{Number One}

In Russian the word for 1, "one", is an adjective and thus varies in case, gender and number according to the noun it enumerates. The plural forms of "one" are used with nouns which occur only in the plural and with nouns or pronouns in the meaning "alone".

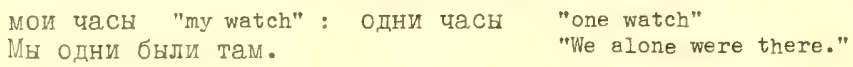

\section{THE RUSSIAN VERB}

From the standpoint of dictionary listing the basic form of the Russian verb is the infinitive. For the vast majority of Russian infinitives the characteristic signal is a final- $\underline{-1}$; for example,

$$
\begin{array}{ll}
\text { чита-ть } & \text { "to read" } \\
\text { писа-ть } & \text { "to write" } \\
\text { Говори-ть } & \text { "to speak" }
\end{array}
$$

A small number of infinitives have the signals:- $\underline{\mathrm{ub}}$ and $-\underline{\mathrm{TH}}$ e.g.,

$$
\begin{array}{ll}
\text { мочь "to be able" } \\
\text { вести }
\end{array}
$$

\section{The Past Tense}

The formation of the Russian past tense is quite simple. There are only four forms and they may be easily derived from the regular infinitive: remove the infinitive signal and add the past tense signal $\underline{\pi}$. An additional $\underline{\underline{a}}$ is suffixed to designate fem. gender, an $\underline{0}$ for the neut. or $\underline{\text { I }}$ for all plural forms.

$$
\begin{aligned}
& \text { работа-ть "to work" } \\
& \left.\begin{array}{l}
\text { я } \\
\text { тн }
\end{array}\right\} \text { paбота-л } \begin{array}{lll}
\text { "I[male] worked, was working" } \\
\text { "You " } & \text { "He " } & \text { " were " was " }
\end{array} \\
& \left.\begin{array}{l}
\text { я } \\
\text { тн } \\
\text { она }
\end{array}\right\} \text { paбота-л-а } \quad \text { "I[female] worked, was working" } \\
& \text { оно работа-л-о "It worked, was working" }
\end{aligned}
$$

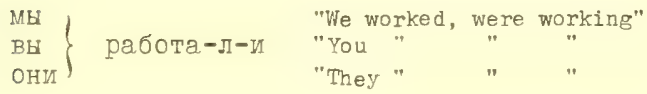

The small number of verbs which have past tense forms not in accordance with this simple pattern will simply be listed in a reference sheet(REFERENCE).

\section{The Present Tense}

The Russian verb has six forms in the "present" tense: three in the singular and three in the plural. There are 2 basic types of present formation and they may be exemplified by the following two sets of forms: 


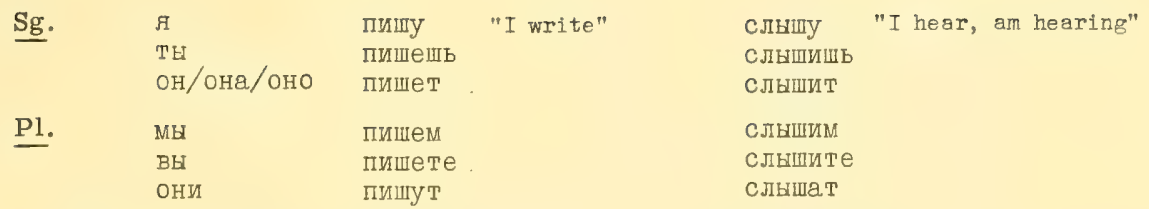

In four forms the two sets are distinguished by a pre-final vowel: $e$ for one set, $\underline{n}$ for the second. The first set has a pre-final vowel $\mathrm{y}$ in the $3 \mathrm{rd}$. pl. form, while the second set has pre-final a in this form. Most variations from these two basic patterns are predictable. Here, for example, are slightly differing types belonging to the first set:

$\begin{array}{llll}\begin{array}{l}\text { буду "I will be" } \\ \text { будешь } \\ \text { будет } \\ \text { берёшь "I take" }\end{array} & \begin{array}{l}\text { знаю "I know" } \\ \text { знаешь } \\ \text { берёт } \\ \text { знает }\end{array} & \begin{array}{l}\text { поюешь "I sing" } \\ \text { поёт }\end{array} \\ \text { будем } & \text { берём } & \text { знаем } & \text { поём } \\ \text { будете } & \text { берёте } & \text { знаете } & \text { поёте } \\ \text { будут } & \text { берут } & \text { знают } & \text { поют }\end{array}$

The pronouns add emphasis and are often, as above, dispensed with. In the forms above the variation $\mathrm{V} / 10$ should be familiar; here the 10 is selected after a vowel, e.g. 3 Ha.10 The "' contrast, for example, берёт and бу́дет. Consider now some variations in the second set:

\begin{tabular}{|c|c|c|c|}
\hline служу "I serve" & Говорю "I speak" & вижу "I see" & лю5лю \\
\hline слунишь & Говоришь & Видишь & любишь \\
\hline служит & говорит & ВИДИТ & любит \\
\hline служим & говорим & ВИДИМ & любим \\
\hline служите & говорите & видите & любите \\
\hline служат & говорят & ВИДЯТ & любят \\
\hline
\end{tabular}

The $3 \mathrm{rd}$. pl. variation of $\mathrm{a} / \underline{\text { g }}$ should also be familiar, while the insertion of an extra consonant in the lst. $\mathrm{sg}$. form of "I love" will seem strange. There are other similar variations special to the 1st. sg. form; these may be considered in the discussion of "Consonant Alternations"(page 32).

The Verb: "to be"

If one looks up the Russian forms of the verb: "to be", the infinitive быть will be found. From this there may be derived the four past tense forms: был была было были Some present forms of this verb are listed on this page, but they have the meaning "will be", etc. Ordinarily, Russian uses no verb forms to express English "is" or "are",e.g.

$$
\begin{array}{ll}
\text { Физика - науна. } & \text { "Physics is a science." } \\
\text { Студенты - больны. } & \text { "The students are 1ll." } \\
\text { Они не мои книги. } & \text { "They are not my books." }
\end{array}
$$

There does exist one form, есть which functions, when used(infrequently), either as a 3 rd. sg. or a 3 rd. pl.; e.g.,
Из этого полояения есть выхоп.
Есть ли у Вас книги?
"From this position there is a way out."
" Do you have(1it.: Are there with you) any books?"

\section{The Imperative}

Orders, commands and exhortations are expressed in Russian in the following ways: 2nd. person imperatives. Since Russian has a singular "you" and a plural "you", there are two such imperative forms. The sg. form is characterized by the ending: $-\underline{H} /-\underline{H} /-\underline{\underline{H}}$; the addition of $-\underline{\mathrm{T}} \mathrm{e}$ makes the pl. form. The base for these imperative forms is the same as that of the present tense. 
The Imperative(continued)

The ending: $\quad-\underline{I I}$

$$
\begin{aligned}
& \text { жИв-и "live!" (они жив-ут) } \\
& \begin{array}{lcl}
\text { жив-И-те " } & \text { (они говор-ят) }
\end{array}
\end{aligned}
$$

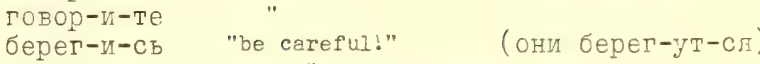

$$
\begin{aligned}
& \text { берег-и-те-сь }
\end{aligned}
$$

The ending: - 萌 is usual when the word base ends in a vowel.

$$
\begin{aligned}
& \text { зна-芩 "know!" (они зна-ют) } \\
& \begin{array}{lll}
\text { зна-й-те } & \text { " } \\
\text { бо-й-ся } & \text { "fear!" }
\end{array} \\
& \text { бо-放-Te-cb } \\
& \text { " }
\end{aligned}
$$

The ending: $-\mathrm{B}$ is used when the word base carries the accent in present tense forms.

$$
\begin{array}{lll}
\text { буд-ь } & \text { "be:" } & \text { (они буд-ут) } \\
\text { буд-ь-те } & " & \\
\text { постав-ь } & \text { "рдасе:" } & \text { (они постав-ят) } \\
\text { постав-ь-те } & " &
\end{array}
$$

3 rd. person imperatives. The Russian equivalents of English expressions such as "Let him do it"/"Let them do it", etc. , are effected by using the forms Пусть Пуснай in conjunction with the regular $3 \mathrm{rd}$. $\mathrm{sg}$. or $3 \mathrm{rd}$. pl. forms of the present tense; e.g. ,

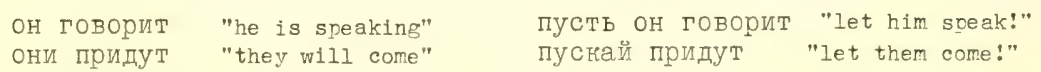

Ist. person plural imperative. This category, rather frequent in scientific texts, simply uses 1st. pl. forms of the present tense without the pronoun; the verb form is usually of perfective aspect, a phenomenon explained in the pages following. Some examples:

$\begin{array}{llll}\text { мн сканем } & \text { we shall say } & \text { спажем } & \text { let us say } \\ \text { мн посмотрим } & \text { we shall look at } & \text { посмотрим } & \text { let us consider } \\ \text { мы предполоним } & \text { we shall assume } & \text { прдполоним let us assume }\end{array}$

\section{INFINITIVES AND PRESENT TENSE FORMS}

For the majority of verbs in Russian there exists a very clear relationship between present tense forms and the infinitive so that, given one, the other can be readily deduced, e.g. ОН ГОворит : ГОворить. There are less obvious relationships, and perhaps the most important of these, since it concerns a verbal type used extensively for the creation of new verbs in Russian, is the following:

\section{Present Tense}

$$
\begin{aligned}
& \text { образую } \\
& \text { образуешв } \\
& \text { образует } \\
& \text { образуем } \\
& \text { образуете } \\
& \text { образуют }
\end{aligned}
$$

\section{Infinitive}

образовать "to form"

Some more examples of this type are:

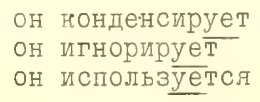

конденсировать

итнорировать

использоваться

\footnotetext{
"to condense"

"to ignore"

"to use"
} 
In this manual an attempt has been made to simplify the statement of present tense : infinitive relationships, since it is assumed that the user is not a career student of the Russian language. To this end the REFERENCE section contains lists of present tense forms which do not accord with the statements below.

Present Tense

Set I

1) $-\mathrm{a}-\mathrm{e}-,-\mathrm{a}-\mathrm{b}-$

$\underline{\text { Infinitive }}$

$-я-e-,-я-\longmapsto-$

$-\mathrm{a}-\mathrm{Tb}$

$-g-T b$

$\begin{array}{lll}\text { он знает } & \text { они знают } \\ \text { он терлет } & \text { они теряют }\end{array}$

знать

терять

"to know"

"to lose"

2) $-\mathrm{e}-\mathrm{e},-\mathrm{-}-1-$

$-e-T b$

$\begin{array}{ll}\text { белеет } & \text { белеют } \\ \text { имеет } & \text { имеют }\end{array}$

белеть

иметь

"to turn white"

3) $-\mathrm{H}-\mathrm{e}-, \quad-\mathrm{H}-\mathrm{y}-$

тонет тонут

кинет кинут

- ну

тонуть

кинуть

"to have"

4) $-\mathrm{y}-\mathrm{e}-, \quad-\mathrm{y}-10-$

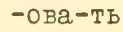

образует образуют

пакует пануют

образовать "to form"

паковать "to pack"

Set II (only one type; all others in

REFERENCE listing)

$\begin{array}{cl}- \text { и- } & ,-\mathrm{a} / \mathrm{r}- \\ \text { говорит } & \text { говорят } \\ \text { учит } & \text { учат }\end{array}$

$-\mathrm{I}-\mathrm{TB}$

говорить

учить

\begin{abstract}
"to speak"
"to teach"
\end{abstract}

\title{
VERBAL ASPECT
}

A beginning student, casually inspecting a Russian dictionary, may well be surprised to note that two Russian infinitives are cited as equivalents of one English verb, e.g.

$$
\begin{array}{ll}
\text { "to write" - писать, написать } \\
\text { "to read" - читать, прочитать }
\end{array}
$$

The basic meaning, of writing or reading, is the same for each member of the pair, but there is a meaning distinction in that the second member( написать, прочитатъ) also implies a completion or limitation of the verbal action. For example,

$$
\begin{aligned}
& \text { Я писал письмо. "I wrote/was writing a letter." } \\
& \text { Я написал письмо. "I wrote[=finished writing] a letter." }
\end{aligned}
$$

Use of the first member писал establishes the idea of an on-going action or state, which may or may not have been eventually brought to a stage of completion; use of the second member of the pair написал, however, makes a definite commitment as to the completion of the verbal action.

This phenomenon is called "aspect", that is, the way a speaker or writer "views" verbal action. It is a characteristic of the Russian verbal system and must be considered when translating from Russian to English.

In aspectual pairs the first member, which signifies enduring action, is traditionally referred to as a verb of imperfective(impf.) aspect, while the second member with its added meaning of completion is called a verb of perfective(pf.) aspect. 
Aspect adds nothing new in the way of distinctive tense forms. The examples on the preceding page showed both aspects being employed in the same type of past formation. Both aspects are also used in what has been termed the "present" tense, but the difference in meaning which results is quite striking. First, some "present" forms:

$$
\begin{array}{ll}
\text { я пишу... он пишет... } \\
\text { я читаю... он читает... }
\end{array}
$$

The present forms of impf. aspect(on the left) are rendered into English with similar present tense forms: "I write/I am writing", "I read/Iam reading", etc., but, since action is not completed in present time and since the past tense of the pf. verbs( написал, прочитал) takes care of past time for the pf. aspect, the above pf.forms can be translated into English only with a future meaning; e.g.,

$$
\begin{aligned}
& \text { Oн напишет письмо. } \\
& \text { Он прочитает ннигу. }
\end{aligned}
$$

"He will write[and finish the writing of] a letter."

"He will read[and finish reading] the book."

This situation is the reason why the term "present tense" has been used in quotation marks. The formation(verb base plus "endings") is the same for all verbs,regardless of aspect, but the meaning is "present" only for impf. verbs. It might more exactly be referred to as "non-past", but "present tense" is the traditional term.

\section{Combination Future}

Future events, where a commitment as to termination is not possible or desired, are expressed by a "combination future" which employs "present tense" forms of a verb meaning "will be" with the infinitive form of a verb of impf. aspect. Thus,

$$
\left.\begin{array}{rl}
\text { я буду } \\
\text { ты будешь } \\
\text { ононано будет } \\
\text { мы будем } \\
\text { вы будете } \\
\text { они будут }
\end{array}\right\}
$$

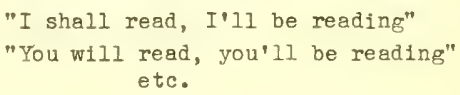

читать

Only infinitives of impf. aspect may be used in this combination future. Now it is possible to contrast this type of future with aspectual future, e.g.

Завтра студент будет читать роман. Завтра студент прочитает роман. "Tomorrow the student will be reading the novel."
"Tomorrow the student will read[and finish
reading] the novel."

Aspectual Pairs - Some Examples

Some frequently used verbs are listed below simply to impress upon the learner the fact of aspectual difference. The $3 \mathrm{rd}$. sg. forms of the "present" are given after the infinitive forms:

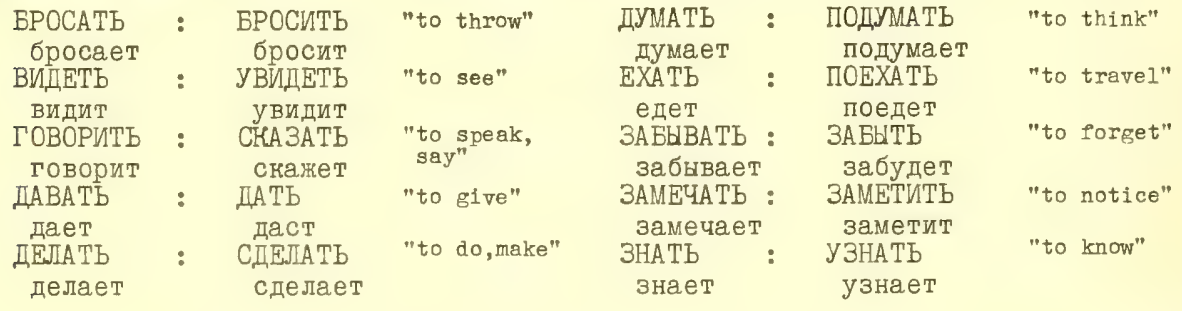




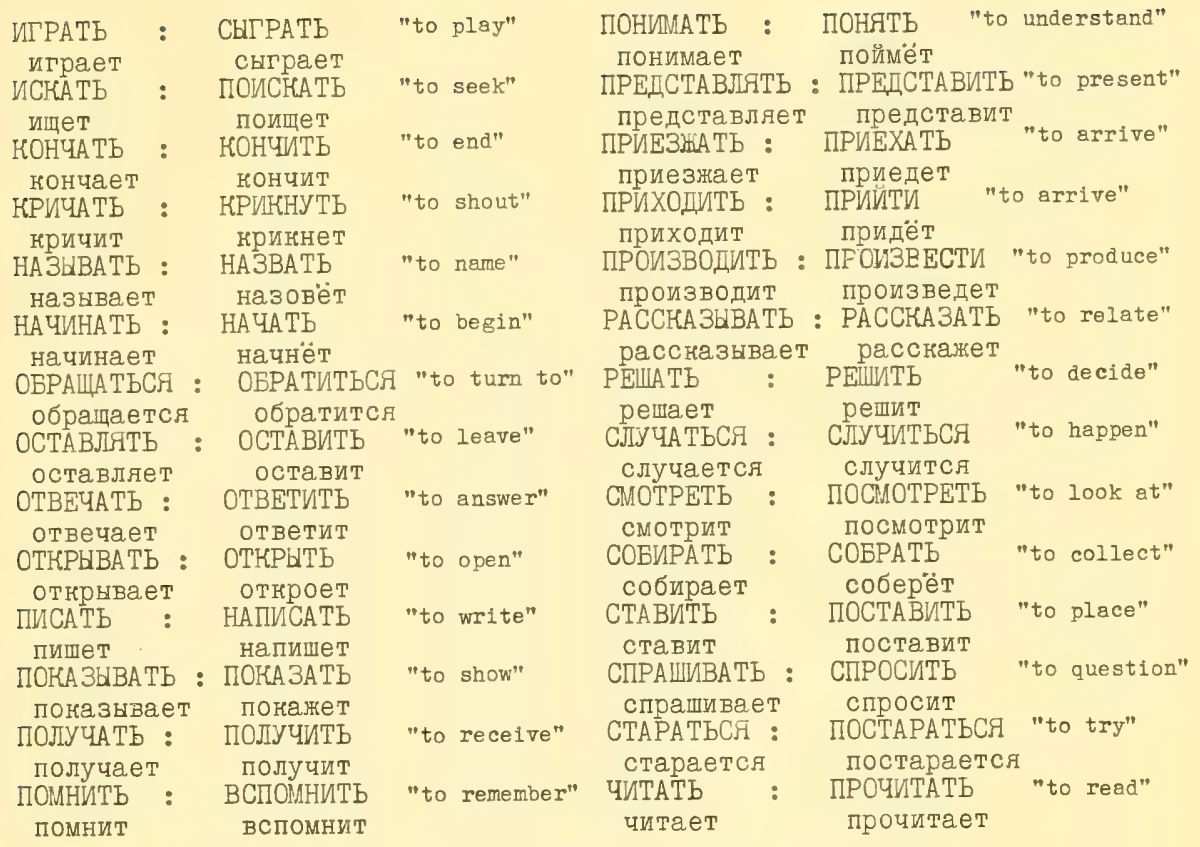

\section{REFLEXIVE FORMS}

The reflexive signal is $-\underline{\mathrm{c} g}$ or $-\underline{\mathrm{Cb}}$ and may occur in final position in the forms of verbs and verbals(treated in a later section). In verb forms - cr appears after consonants, $\underline{\underline{i}}$ and $\underline{b}$, while $-\underline{c b}$ appears only after vowels. Some examples are:

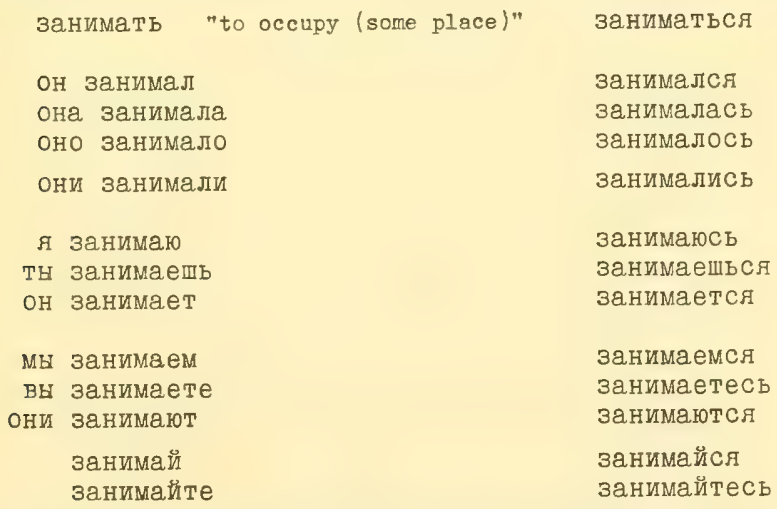

The reflexive signal does not make any difference in form, that is, a present tense form is still in the present tense, with or without the reflexive ending. There will, however, be a difference in meaning and here the learner must depend on his dictionary. In general, the reflexive signal will, depending on the particular verb, be interpreted as: 
Reflexive(continued)

1) reflexive: the action of the verb is not terminated in an object but is referred back ("reflected back") to the subject, e.g.

$\begin{array}{ll}\text { OH бреет... } & \text { "He shaves (someone)." } \\ \text { Oн бреетс.. } & \text { "He shaves (himself)." }\end{array}$

2)passive; e.g. ,

Она товорит это.

"She says this."

Әто не говорится по-русски. "This is not said in Russian."

3) reciprocal; e.g.,

Мать целует дочь.

Мать и дочь целуются.

"The mother kisses the daughter."
"The mother and daughter kiss(i.e.
each other)."

4) having no special meaning: this is so for a small number of verbs which occur only with these "reflexive" endings. A few examples:
смеяться "to laugh
бояться "to fear
Мн смеллись.
"We were laughing."
Я боюсь әнзамена.
"I'm afraid of the exam."
стараться "to try"
Он старается смеяться. "Hе's trying to laugh."

It should be noted that a reflexive verb form (or verbal) is never followed by the accusative case.

\section{Verbs and Cases}

In Russian sentences of the type: "The boy is reading the paper", the subject("boy") will be a noun in the $\mathrm{N}$ case and the object("paper") will usually be in the A case. Certain verbs, however, have their objects in other cases; e.g.,
избетать
помогать
править
$[+G]$
$\mathrm{OH}_{\mathrm{H}}$ избегает вопроса.
$[+D]$
Учитель помогает студенту.
$[+\mathrm{I}]$
Они правят страной.
"He aroids the question."
"The teacher helps the student."
"They govern the country."

The verb in the last example is one of a sizeable number which are followed by a noun or adjective in the I case. Some frequently used verbs which "govern" the I case are:

бнть
владеть
воспользоваться (pf.)
пелаться
заниматься
интересоваться
назваться (pf.)
называться
обладать
оназаться (pf.)
оназываться
оставаться
остаться (pf.)
пользоваться
сделаться (pf.)
становиться
стать (рf.)
считаться
управлять
являться

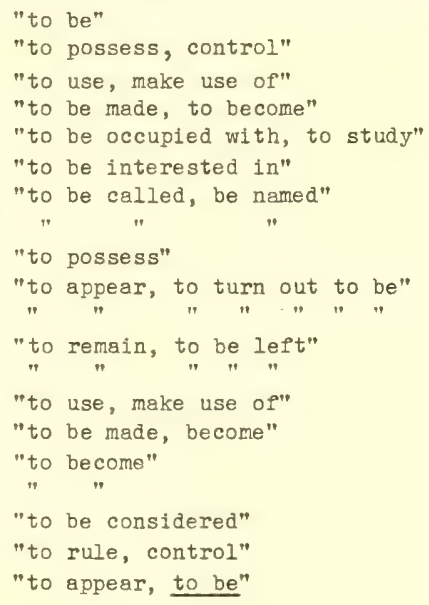


$\underline{\sigma_{H}}$

This particle is used with past tense forms of the verb or with infinitives to express conditions which might have taken place but did not, or conditions which might exist in the future but probably will not. Of the various traditional names applied to this construction perhaps the most descriptive is a "contrary-to-fact condition". An example is:

Если бы моленула бнла последним

"нирпичом мироздания", то на әтом

рассмотрение энергетичесних пре-

вращений можно было бы занончить.

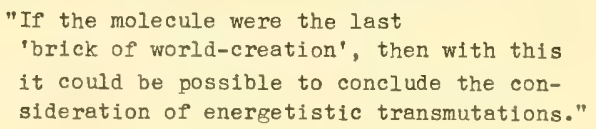

чтобн

This connective is used after verbs of wishing, e.g.

$$
\text { Я хочу, чтобн он сделал это. "I want him to do this." }
$$

or simply with the meaning "in order to". If the subject of the чтобы clause is the same as that of the main clause, an infinitive may be used, e.g.

Я вернулся, чтобн она могла поговорить со мной.

Я вернулся, чтобн поговорить

с ней.

Является, являются

In written Russian the above two forms(3rd. sg. and $3 \mathrm{rd}$. pl. present) of the verb являться "to appear", are used very often in the verbal meaning "to be", that is, "is" and "are" respectively. The subject noun will be in the $\mathrm{N}$ case but the noun or adjective to which it is equated will be in the I case. For example,

Основнеми магнитными харантеристинами

магнитной плёнки являются её остаточная

магнитная индукция и коэрцитивная сила.

\begin{abstract}
"Its residual magnetic induction and coercive force are the basic magnetic characteristics of magnetic tape."
\end{abstract}

Special Use of 3rd. pl. Form of Verb

A 3rd. pl. form of the verb may appear without an expressed subject and equate, in translation, to an English passive construction. Some examples are:

\section{Здесь говорят по-русски . \\ Температуру возпуха измеряют \\ с помощью метеорограбов ...}

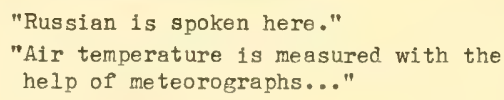

$\underline{\text { Negation }}$

The two particles which are used in Russian to express negation are:

$$
\begin{array}{ll}
\text { He "not" } & \\
\text { нет "no, there is not/there are not" }
\end{array}
$$

The particle He is used in simple equational statements, with verbs and in conjunction with adjectives, e.g.

$$
\begin{array}{ll}
\text { Петров не физик. } & \text { "Petrov is not a physicist." } \\
\text { Я не вину города. "I don't see the c1ty." } \\
\text { Әто небольшой дом. "That's a small[not large] house." }
\end{array}
$$

The particle $\underline{\mathrm{HeT}}$ may be used by itself as an answer or it may be used with other words in short sentences, e.g. 
Negation(continued)

$$
\begin{aligned}
& \text { Вы Петров? Нет. "Are you Petrov?" "No." } \\
& \text { Там нет столов. }
\end{aligned}
$$

In the last example there is illustrated the use of the genitive case after HeT, as is the situation also after verbs negated with He.

The и...и... which mean "both... and..." in positive statements become ни.... ни... "neither...nor..." in negative statements.

\section{Double Negation}

In contrast to the situation in standard English, the doubling of negative words serves only to intensify the negation. An example:

Я никогда никому ничего не давал. "I never gave anything to anybody." [11t.: I never to nobody nothing didn't give.]

This repetition of negatives is also a feature of sub-standard English, and the English sentence in brackets above would be, with a different word-order, no stranger to the ears of English-speakers.

\section{Questions}

Questions are formed in Russian by the use of question words("who", "when", etc.), by placing the verb before the subject with or without the question particle $\underline{\text { II }}$, or by using the statement order with question intonation(Spoken Russian).

$$
\begin{aligned}
& \text { Statement: } \quad \mathrm{OH} \text { знает ypok. "He knows the lesson." } \\
& \text { Question: Kто внает ypor? "Who knows the lesson." } \\
& \text { Знает ли он урок? "Does he know the lesson?" } \\
& \text { Знает он урон? } \\
& \text { OH знает урон?[Spoken Russian] " " }
\end{aligned}
$$

ли, which indicates a question, appears in second position in the sentence or in third, if the verb is negated; in indirect questions ли may best be translated by "whether".

$$
\text { Я не знаю, придёт ли она. "I don't know, whether she'll come." }
$$

Use of Свой, Своё, Своя, …

The usage of this possessive adjective may best be shown by the following series of short statements:

$$
\begin{aligned}
& \text { Я делаю "I do my work." } \\
& \text { Tн делаеmь "You do your work." } \\
& \text { Он/Она/Оно делает свон работу." "He/She/It does his/her/its work." } \\
& \text { Mн делаем }\{\text { свою paботу • "We do our work." } \\
& \mathrm{B}_{\mathrm{b}} \text { делаете "You do your work." } \\
& \text { Онг делают "They do their work." }
\end{aligned}
$$

Russian distinguishes explicitly between "his" and "his own", "her" and "her own", "their" and "their own". Observe the following contrasts:

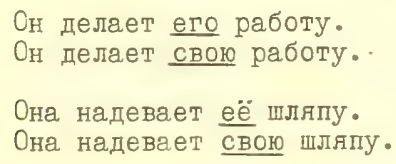

$\mathrm{O}_{\mathrm{H}}$ делает его работу.

Она надевает её шляпу.

Она надевает свою шляпу.

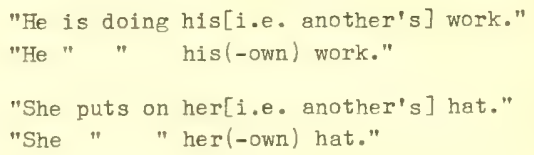




\section{Russian Names}

A Russian's name has three constituent parts, all nouns: a first name("Christian name"), a middle name which is a patronymic, and a last name. For example, the names of a brother and sister, whose father's first name is "Peter", would be:

$$
\begin{array}{ll}
\text { Иван Петрович Иванов } & \text { (John Peter-son Jones) } \\
\text { Вера Петровна. Иванова } & \text { (Vera Peter-daughter Jones) }
\end{array}
$$

As shown, the patronymic(i.e. name reference to father) is derived from the father's first name by the suffixation of $-\underline{\mathrm{OBII}} /-\underline{\mathrm{eBIU}}$ for the son and -OBHa/-eBHa for the daughter.

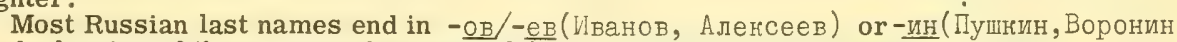
The declension of these names has special features which may be looked at, when necessary, in the listing in Section II (PARADIGMS).

Russian last names in- СЕй̈ have adjectival forms(see page 15).

\section{Adverbs from Adjectives}

A number of adverbs are identical in form with the neuter short form(page 19) of a related adjective, e.g.

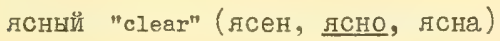

$$
\begin{aligned}
& \text { широкий "wide"(широк, широко, пирока) }
\end{aligned}
$$

Adjectives ending in - Сииц have no short forms, but their related adverbs are characterized by -

герметичесий

герметичесни занритый аппарат

"a hermetically sealed apparatus"

\section{Use of Adverbs}

The unchanging forms known as "adverbs" have many uses, a few of which are:

1) with verbs;

2) with adjectives;

Он хорошо говорит.

нрайне внсоная стоимость

3) with infinitives;
Магнитную плёнку можно многонратно использовать...

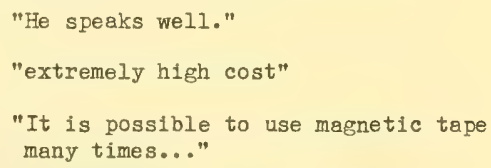

The last example, in which the adverb also signals the verbal idea, "it is", occurs frequently in Russian. In close proximity in one scientific text four sentences began with this adverb construction:

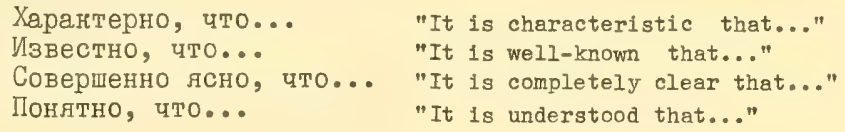

Impersonal Constructions

A few examples will suffice to indicate the nature of this type of construction. Thus, Так нан в CIIA не имелось в то времн разработанных образцов ...

"Since there were no[lit.: it was not had] developed models in the USA at that time..."

...снаряды следует классифицировать по дальностй стрельбы...

"Missiles should be classified[lit.: 1t follows/one must classify missiles] according to range..." 


\section{Consonant Alternations}

In certain definite situations some consonants alternate regularly with other consonants. These alternations are so characteristic of Russian structure that the learner should familiarize himself with them. Of the several categories affected by these alternations only the three most important for the beginner are offered:

1) lst. sg. present tense forms of $\underline{\underline{n}}$ verbs, e.g. Я люблю "I love" : Он любит

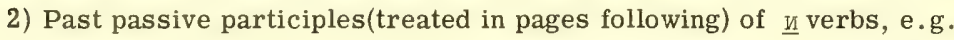

3) Word derivation; e.g. ,

$$
\text { отмеченний "marked" : отметить "to mark" }
$$

$$
\text { свет "light" : просвещение "education" }
$$

\begin{tabular}{|c|c|c|c|c|c|}
\hline$\Gamma$ & Ж & MHOГO & "much" & MHOHECTBO & "great quantity" \\
\hline 3 & $\nVdash$ & возить & "to convey" & я вонгу (ТЫ во & $3 и ш ь$...) \\
\hline I & $\mathbb{W}$ & студить & "to cool" & стуженный & "chilled" \\
\hline - & ЖI & рассудите & b "to discuss & рассуждать & "to discuss(impr.)" \\
\hline - & ч & ВОСТОК & "East" & Восточный & "eastern" \\
\hline - & ૫ & уплатить & "to pay" & я уплачу (ты & уплатишь ....) \\
\hline $\mathrm{T}$ & 近 & свет & "light" & освенение & "illumination" \\
\hline $\mathrm{CT}$ & II & выпустить & b "to release & выпущенный & "released" \\
\hline $\mathrm{CK}^{-}-$ & II & $\mathrm{BOCH}$ & "wax" & вопить & "to wax" \\
\hline c & III & носить & "to wear" & я ношу ( & сишь ....) \\
\hline - & III & страх & "fear" & страшный & "frightful" \\
\hline - & ПЛ & топить & "to heat" & отопление & "heating" \\
\hline 6 & бл & срубить & "to cut down & срубленный & "cut down" \\
\hline M & $M \pi$ & нормить & "to feed" & нормление & "nursing" \\
\hline - & BJI & добавить & "to add" & побавленннй & "added" \\
\hline - & क्रा & графить & $\begin{array}{l}\text { "to draw } \\
\text { lines" }\end{array}$ & я граблюю (ты & графишь ...) \\
\hline
\end{tabular}

The consonant alternations are the following:

\section{VERBALS(Participles and Gerunds)}

The six grammatical categories called verbals have the following characteristics: 1) They are formed from verbs; 2) Once formed, they are either adverbs(gerunds) and so have no further change of ending, or else they are adjectives with appropriate adjective endings; and 3) They may be followed, as are verbs, by dependent ac'.ectives and nouns. The names of these verbals are:

Participles(Verbal Adjectives) - 4 in number

1) Present Active Participle - the "now doing (something)" form

2) Present Passive Participle - the "now being done" form

3) Past Active Participle - the "having done (something)" form

4) Past Passive Participle -the "having been done" form

Gerunds(Verbal Adverbs) - 2 in number

A) Present Gerund - the "doing"/"when doing"/"while doing" form

B) Past Gerund - the "having done"/ "after having done" form 
$\underline{\text { Participles }}$

1) Present Active Participles are characterized by the letter щ before the adjectival endings. Identifying the related verb(a necessary process since dictionaries do not list participles or gerunds) may be accomplished by comparing the participial form with the $3 \mathrm{rd}$. pl. form of the present tense, as follows:

$$
\begin{array}{lll}
\text { грею-щ-ий } & \text { "warming" } & \text { они грею-т : греть } \\
\text { работаю-ц-ий } & \text { "working" } & \text { они работаю-т : работать }
\end{array}
$$

Почти все биохимические реации, происходящие в живых телах и в своём "Almost all biochemical reactions, which take place in living bodies and which in занономерном сочетании составляющи обмен веществ, катализируются their normal combining involve an exchange of substances, are catalyzed соответствуюими ферментами. (происходящий:они происходят) by corresponding enzymes." ( составляюий: они составляют) ( Соответствуюцй: : они Соответствуют)

NOTE: A present a c ti ve participle may be identified by the letter ㅆ plus adjective endings plus or minus the reflexive ending $\mathrm{C} f$ (never $-\underline{\mathrm{Cb}}$ )

2) Present Passive Participles are, in appearance, similar to the 1st. pl. form of the present tense with suffixed adjectival endings. Some participial forms are:

$$
\begin{array}{llll}
\text { называемый } & \text { "named, called" } & \text { мы называем } & : \text { называть } \\
\text { высушиваемый "being evaporated" } & \text { мы высушиваем } \\
\text { используемый } & \text { "being used" высушивать } \\
\text { видимый } & \text { "being seen, visible мы видим }
\end{array}
$$

NOTE: A present passive participles may be identified by the letter $M$ plus adjectival endings.

3) Past Active Participles are characterized by the letter $\underline{\Psi}$ or the letters BU before adjectival endings. In the case of a participle with the letters $\mathrm{B} \amalg$, the infinitive relationship may be easily established. To identify the infinitive for the - III- forms is more complicated and so such participles are listed with their infinitives in a reference sheet(REFERENCE).

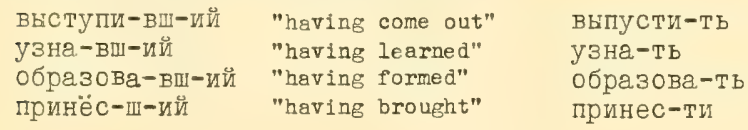

Приведены сведения об итальянском исследователе-электрофизиологе Карло Мтеуеучи, изучавшем химические действия элентрического тона и опублиновевшем в 1835 году внводы ...
"Included are data about the Italian electro-physiologist Carlo Matteucci, who studied the chem. actions of electrical current and who published [his] conclusions in $1835 \ldots$

NOTE: The characteristic mark of the past active participle is $\underline{B}$ / $\underline{B I}$, II plus

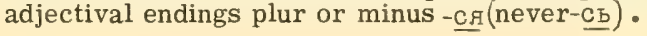


Participles(continued)

4) Past Passive Participles are the most frequently used of all the participial types.

The characteristic signal of the past passive participle is $-\mathrm{HH}_{-}$- plus adjectival endings; there is a small number of these participles which are characterized by ${ }_{-T^{-}}$plus adjectival endings and these will be listed on a reference sheet(REFERENCE).

Participles in $-\underline{a-H H}-$ are formed from infinitives in $-\underline{-a-T b}$

\begin{tabular}{|c|c|c|}
\hline $\begin{array}{l}\text { танннй } \\
\text { нй }\end{array}$ & $\begin{array}{l}\text { "worked out" } \\
\text { "described" }\end{array}$ & $\begin{array}{l}\text { разработа-ть } \\
\text { описа-ть }\end{array}$ \\
\hline
\end{tabular}

Participles in -еннй̆/-ённнй are formed usually from infinitives in -Итъ. A special reference sheet will list such participles formed from other infinitive types.
изученншй
"learned"
изучить
"to learn"
установленный "established"
установить
"to establish"

In the short adjectival forms, which are frequently used, only one $\underline{H}$ appears, e.g.

$$
\begin{aligned}
& \text { (описаннй описанное описанная описаннне) } \\
& \text { etc. } \\
& \text { описан описано описана описань }
\end{aligned}
$$

An example of usage:

$$
\begin{aligned}
& \text { На рисунге } 4 \text { изображена вануум-сушильная установна ... } \\
& \text { "In figure } 4 \text { a vacuum-drying installation is pictured..." } \\
& \text { ( } \begin{array}{l}
\text { изображённый "pictured" : изобразить "to picture") } \\
\text { изображён }
\end{array}
\end{aligned}
$$

NOTE: The characteristic mark of the past passive participle is \#H plus adjectival endings.

\section{Gerunds(Verbal Adverbs)}

A Present Gerunds have as a characteristic signal a final-a or a final-․ㅛ.As adverbs, the gerunds are unchanging in form. Some examples are:

$$
\begin{array}{lll}
\text { жив-я "living, while living } & \text { они жив-ут } \\
\text { держ-а "holding, while holding" } & \text { они держ-ат } \\
\text { говор-я "speaking, while speaking" } & \text { они Говор-ят } \\
\text { зна-я } & \text { "knowing, while knowing" } & \text { они зна-ют } \\
\text { пряч-а "hiding, while hiding" } & \text { они пряч-ут } \\
\text { внй-я "having departed" } & \text { они вый-ут } \\
\text { занима-я-сь "studying" } & \text { они занима-ют-ся }
\end{array}
$$

The $3 \mathrm{rd}$. pl. forms of the present tense are given above, since they are a helpful guide in the formation of present gerunds. An example of usage is:

Магнитную плёнку можно многократно использовать, стирая заранее записаннее звуии.

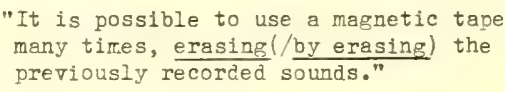

NOTE: The characteristic mark of the present gerund is $-a /-g$ p plus or minus the reflexive ending $-\underline{\mathrm{Cb}}$. 
B Past Gerunds are distinguished by the signals - B or - ВШИ in final position. A limited number of verbs have the signal are listed in a reference sheet(REFERENCE). In the examples below infinitive forms are cited, since they provide the best 'point of departure' in the formation of the past gerunds.

$$
\begin{aligned}
& \text { сдела-в }\} \quad \text { (сдела-ть) "having done, after having done" } \\
& \text { спела-вши }\} \\
& \text { viмe-B (име-ть) "having had, after having had" }
\end{aligned}
$$

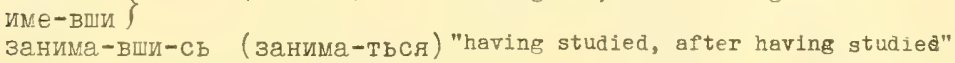

$$
\begin{aligned}
& \begin{array}{l}
\text { Прочитав статью, он дал "After he read the article, he gave it to [his] } \\
\text { eе́ поллеге. }
\end{array}
\end{aligned}
$$

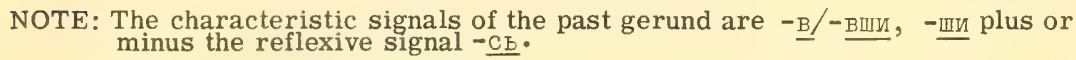

\section{Translation of Gerunds}

Regardless of the terms: "present" or "past", the English translation of the gerunds is basically determined by the aspect of verb used. If the gerund represents a verb of imperfective aspect, the action or status signified by the verb is taking place at the same time as that of the principal verb of the sentence, e.g. "while living in the city, he studied Russian". If the aspect is perfective, the meaning of the gerund applies to a prior time, e.g. "having left the city/after he had left the city, he took up the study of Russian".

\section{Participles and Gerunds of Reflexive Verbs}

On page 27 it was stated that the reflexive signal -ç occurs in verb forms after a consonant, while $-\underline{C b}$ is used after a vowel. Though this statement is valid for gerunds,

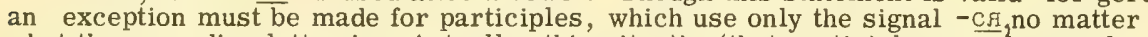
what the preceding letter is. Actually, this situation(that participles may have only $-\underline{\mathrm{c} f}$ while gerunds use only $-\underline{\mathrm{Cb}}$ ) is helpful to the student in distinguishing forms which are quite similar, e.g.

$$
\begin{array}{ll}
\text { занимавшись } & =\text { Past Gerund } \\
\text { 3анимавпиеся } & =\text { NA-pl. of Past Active Participle }
\end{array}
$$

\section{WORD ORDER}

Russian word order seems remarkably free to a speaker of English, who is habituated to the rigid patterns of word sequence in the English language. If care is exercised in identifying grammatical signals("endings"), the beginner should have no trouble, even with such sentences as the following:

\footnotetext{
Более өнономичную конструкцию имеют те цинлические уснорители, ...

( A more economical construction[<A] have[3rd.pl.] those cyclical accelerators[NA-pl.]...)

"Those cyclical accelerators,..., have a more economical construction."
}

Возможно, что здесь основную роль будут играть радиолонөционные методн.

("It is possible, that here the basic rôle will play radio-location methods.")

"It is possible, that radio-location methods will play the basic rôle here." 


\title{
SECTION II
}

\author{
PAR ADIG MS
}

A paradigm is, according to Webster, "an example of a conjugation or declension, showing a word in all its inflectional forms." This section is therefore a collection of such grammatical sets and will prove to be a valuable resource for the student who has forgotten the analysis of the preceding section and yet wishes to view something more substantial than the lists of "endings" in the following section.

\section{NOUNS *}

Masculine singular

Neuter singular

\begin{tabular}{|c|c|c|}
\hline $\mathbb{N}$ & СTOJ & студент \\
\hline A & CTOJ & студент-а* \\
\hline G & стол-а & студент-а. \\
\hline $\mathrm{D}$ & стол-у & студент-у \\
\hline & стол-е & студент-е \\
\hline$I$ & СTOЛ-OM & студент-ом \\
\hline & корабл-ь & корол-ь \\
\hline & норабл-ь & норол-я ** \\
\hline$G$ & корабл-я & Корол-я \\
\hline D & корабл & Корол-ю \\
\hline$P$ & норабл-е & корол-е \\
\hline$I$ & норабл-ём & норол-ём \\
\hline$N$ & отец & палец \\
\hline A & отц-а** & палец \\
\hline G & отц-а & пальц-а \\
\hline D & ОТц-У & пальц-у \\
\hline$P$ & отц-е & па льц -е \\
\hline I & ОТц-ОМ & пальц-ем \\
\hline $\mathbb{N}$ & 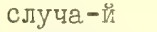 & Гени-前 \\
\hline A & случа-й & Гени -я** \\
\hline G & случа-д & Гени-я \\
\hline D & случа - 10 & Гени-ю \\
\hline$P$ & случа-е & гени-и \\
\hline$I$ & случа-ем & гени-ем \\
\hline $\mathbb{N}$ & рот & ден-Б \\
\hline A & роT & пен-ь \\
\hline$G$ & $p T-a$ & ДН-Я \\
\hline$D$ & $\mathrm{pT}-\mathrm{y}$ & ДН \\
\hline$F$ & рт-e & ПH-e \\
\hline & $\mathrm{PT}-\mathrm{OM}$ & ДH-ём \\
\hline
\end{tabular}

$\begin{array}{ll}\text { озер-о } & \text { мест-о } \\ \text { озер-о } & \text { мест-о } \\ \text { сзер-а } & \text { мест-а } \\ \text { озер-у } & \text { мест-у } \\ \text { озер-е } & \text { мест-е } \\ \text { озер-ом } & \text { мест-ом } \\ \text { онн-о } & \\ \text { онн-о } & \text { пол-е } \\ \text { онн-а } & \text { пол-е } \\ \text { онн-у } & \text { пол-я } \\ \text { онн-е } & \text { пол-ю } \\ \text { онн-ом } & \text { пол-е } \\ \text { ружь-е } & \text { пол-ем } \\ \text { ружь-ё } & \text { зпани-е } \\ \text { ружь-я } & \text { зпани-е } \\ \text { ружь-ю } & \text { зпани-я } \\ \text { ружь-е } & \text { здани-ю } \\ \text { ружь-ём } & \text { здани-и } \\ \text { изменени-е } & \text { зпани-ем } \\ \text { изменени-е } & \text { действи-е } \\ \text { изменени-я } & \text { пействи-е } \\ \text { изменени-ю } & \text { действи-я } \\ \text { изменени-и } & \text { действи-ю } \\ \text { изменени-ем } & \text { действи-и } \\ \text { действи-ем } & \end{array}$

чувств-о мнени-е

чувств-о мнени-е

чувств-а мнени-я

чувств-у мнени-ю

чувств-е мнени-и

чувств-ом мнени-ем

* The meanings of the masc. nouns are: table student, ship king, father finger, event genius, mouth day; the neut. nouns have the following meanings: lake place, window field, gun building, change action, feeling opinion.

** Animate nouns (see page 12). 
Feminine singular - type $\mathrm{C}(\mathrm{N}-\mathrm{sg}$. in $-\mathrm{a} / \mathrm{-r}) *$

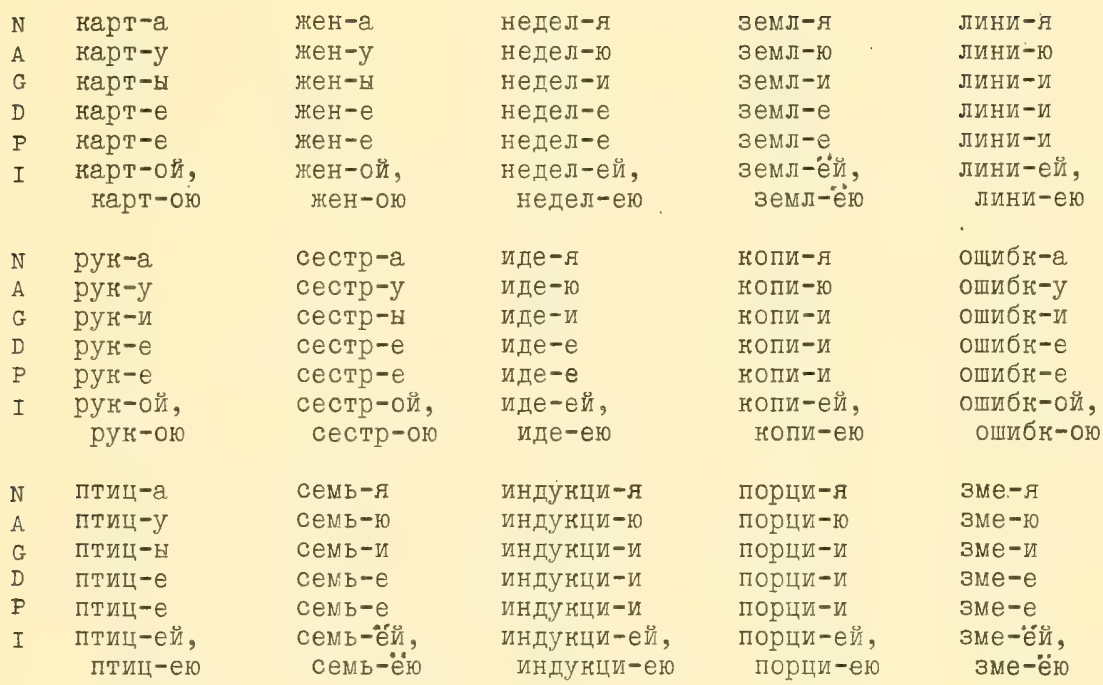

\section{Feminine singular - type $\mathrm{D}(\mathrm{N}-\mathrm{sg}$, in $-\mathrm{b}) * *$}

\begin{tabular}{|c|c|c|c|}
\hline двер-в & вещ - b & ВОЗМОЖHOCT-Б & CKOPOCT-Б \\
\hline двер-ь & веп-ь & ВОЗМОЖНОСТ-Б & СКOPOCT-B \\
\hline двер-и & Вещ-I & ВОЗМОЖНОСТ-И & СHOPOCT-II \\
\hline пвер-и & Вещ-и & ВОЗМОЖНОСТ-И & СКорост-и \\
\hline Пвер-й & ВеЕ-и & ВОЗМОЖНОСТ-И & снорост-и \\
\hline Двер-ью & вещ-ью & ВОЗМОЖНОСТ-БЮ & СНОРОСТ-ЬH \\
\hline MHII - b & HOBOCT $-\mathrm{b}$ & $\mathrm{HOU}-\mathrm{b}$ & ПОДрОбност-Б \\
\hline МВШ-Б & HOBOCT-b & HOY $-\mathrm{B}$ & Подробност-Б \\
\hline MHII-U & НОВОСТ-И & НОЧ $-И$ & подробност-и \\
\hline МВШーИ & НОВОСТ-ע & HOII - II & попробност-и \\
\hline МВші-И & IOBOCT-I & НОч $-и$ & подробност-и \\
\hline MЕШ-БFО & НОВОСТ-Бю & HOU一ーью & ПопрОбноСт-Бн \\
\hline
\end{tabular}

* From left to right the meanings are: map wife week land line; hand sister idea copy mistake; bird family induction portion snake.

** The meanings of the Russian words in type D are (from left to right): door thing opportunity speed; mouse news night detail. 


$\begin{array}{ll}\mathrm{N} & \text { стол-H } \\ \mathrm{A} & \text { стол-H } \\ \mathrm{G} & \text { стол-ов } \\ \text { D } & \text { стол-аM } \\ \text { P } & \text { стол-аX } \\ \text { I } & \text { стол-ами }\end{array}$

N корабл-и

A пеорабл-и

G норабл-ей

D корабл-ям

P торабл-ях

I корабл-ями студент-ы

студент-ов*

студент-OB

студент-ам

студент-ax

студент-ами

норол-и

норол-ей *

норол-ей

норол-ям

норол-яХ

норол-яМи

пальц-ы
пальц-ы
пальц-ев
пальц-ам
па.льц-ах
па.льц-амц

Гени-и

Гени-ев*

гени-ев

Геніи-яM

Гени

гени-ями озер-a

озёр-а

$03 \ddot{\mathrm{e} p}$

озёp-aм

osép-ax

озёр-ами

OHE-a

OHH-a

$\mathrm{OHOH}$

OKH $-2 \mathrm{M}$

$\mathrm{OHH}-\mathrm{ax}$

OHH-aMn

Ружь-я

ружь-я

руж-ei

рущь-ям

ружь-ях

РУжь-ями

изменени-я

изменени-я

изменени-и

изменени-ям

изменени-ях

изменени-ями

чувств-а

чувСтв-а

чувств

чу $B C T B-a M$

чу $B C$ ' $B-a x$

чувств-ами
Mecr-a

Mect-a

Mect

мест-aM

Mect-ax

мест-ами

ПОЛ -я

ПОЛ-Я

Пол-еи

กО JI-भM

ПОЛ-яX

ПОЛ-ЯМИ

Зпани-я

здани-я

зпани-й

здани-ям

здани-ях

здани-ями

дейст Ви-я действи-я де стви-й действи-ям действи-ях дей сти-ями

мнени-я

мнени-я

мнени- Й

мнени-ям

Мнени- $\boldsymbol{F X}$

мнени-भми

*Animate nouns(see page 12). 
Feminine plural - type C

\begin{tabular}{|c|c|c|c|c|c|}
\hline $\mathrm{N}$ & нарт-н & $\nVdash \ddot{e}=$ & недел-и & земл-и & Лини \\
\hline A & нарт-ы & ॠён * & недел-и & земл-и & линиーи \\
\hline G & карт & ऑёH & недел-ь & земел-ь & 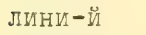 \\
\hline D & нарт -ам & жён-aM & непел-ям & земл-ям & лини-яМ \\
\hline$P$ & нарт-ах & Hëн-ax & недел-ях & земл-ях & лини-яХ \\
\hline I & нарт-ами & жён-ами & недел-ями & земл-ями & Лини - ями \\
\hline N & рук-и & сёстр-и & иде-и & нопи-И & ошибк $-и$ \\
\hline A & рук-и & сестёр* & иде-и & копи -и & ошибк -и \\
\hline G & рук & сестёр & иде -й & Копи-Й & ошибок \\
\hline D & рун-ам & сёстр-ам & иде-ям & НопИ-ЯМ & ошибю-ам \\
\hline$P$ & рук-ах & сёстр-ах & иде-ях & копи-ях & оти $\sigma_{\mathrm{K}}-\mathrm{ax}$ \\
\hline I & рук-ами & сёстр-ами & иде-ями & копи-ями & ощи бк-ами \\
\hline $\mathrm{N}$ & птиц-ы & семь-и & индунци -и & порци-и & зме-и \\
\hline A & Птиц * & семь-и & индунци-и & порци -и & 3мe-Ĭ * \\
\hline G & птиц & ceм-eй & индуюци -й & порци-й & 3мe-泣 \\
\hline D & Птиц-ам & семь-ям & индукци -ям & порци-ям & зме-ям \\
\hline $\mathrm{P}$ & птиц-ах & семь-яХ & индунци -ях & порци-ях & $3 M e-f X$ \\
\hline I & птиц-ами & семь-ями & индукци -ЯМИ & порци-ями & эме-ями \\
\hline
\end{tabular}

\section{Feminine plural - type D}

$\begin{array}{ll}\text { N } & \text { двер-и } \\ \text { A } & \text { двер-й } \\ \text { G } & \text { двер-ей } \\ \text { D } & \text { двер-ям } \\ \text { P } & \text { двер-ях } \\ \text { I } & \text { двер-ями } \\ & \\ \text { N } & \text { мып-и } \\ \text { A } & \text { мыш-ей* } \\ \text { G } & \text { мып-ей } \\ \text { D } & \text { мыШ-ам } \\ \text { P } & \text { мып-ах } \\ \text { I } & \text { мып-ами }\end{array}$

$$
\begin{aligned}
& \text { вец-и } \\
& \text { вец-и } \\
& \text { вещ-ей } \\
& \text { вец-ам } \\
& \text { вец-ах } \\
& \text { вец-ами }
\end{aligned}
$$

НОВОСТ-И
НОВОСТ-И
НОВОСТ-еЙ
НОВОСТ-ЯМ
НОВОСт-ЯХ
НОВОСТ-ЯМИ

Ноч -И

ноч - И

ноч-ей

Hоч-aM

ноч-ax

ноч-ами

$$
\begin{aligned}
& \text { Снорост-И } \\
& \text { Снорост-И } \\
& \text { Снорост-еЙ } \\
& \text { Снорост-яМ } \\
& \text { Снорост-яХ } \\
& \text { Снорост-ЯМи }
\end{aligned}
$$

$$
\begin{aligned}
& \text { подробност-и } \\
& \text { подробност-и } \\
& \text { подробност-ей } \\
& \text { подробност-ям } \\
& \text { подробност-яХ } \\
& \text { подробност-ями }
\end{aligned}
$$


ноторый "

\begin{tabular}{|c|c|c|c|c|}
\hline & masc. & neut. & fers. & pl. \\
\hline $\mathrm{N}$ & ноторый & ноторое & ноторая & ноторые \\
\hline A & $\begin{array}{l}\text { готорый, } \\
\text { ноторого }\end{array}$ & ноторое & ноторую & $\begin{array}{l}\text { ноторне, } \\
\text { поторнх }\end{array}$ \\
\hline G & & ноторого & которой & ноторых \\
\hline D & & которому & ноторой & ноторнм \\
\hline$P$ & & нотором & ноторой & ноторых \\
\hline$I$ & & ноторым & $\begin{array}{l}\text { ноторой, } \\
\text { ноторою }\end{array}$ & которыми \\
\hline
\end{tabular}

\section{Special Nouns}

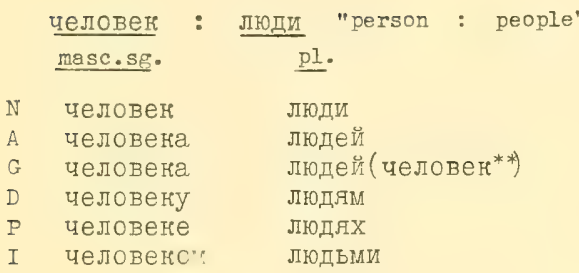

MaTb, дочb "mother, daughter"

fem. sg.

$\begin{array}{lll}\text { N } & \text { мать } & \text { дочь } \\ \text { A } & \text { мать } & \text { дочь } \\ \text { G } & \text { матери } & \text { дочери } \\ \text { D } & \text { матери } & \text { дсчери } \\ \text { P } & \text { матери } & \text { дочери } \\ \text { I } & \text { матерью } & \text { почерью }\end{array}$

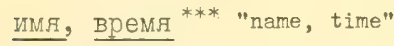

neut. sg.

$\begin{array}{lll}\text { N } & \text { имл } & \text { время } \\ \text { A } & \text { имл } & \text { время } \\ \text { G } & \text { имени } & \text { времени } \\ \text { D } & \text { имени } & \text { времени } \\ \text { D } & \text { имени } & \text { времени } \\ \text { I } & \text { именем } & \text { временем }\end{array}$

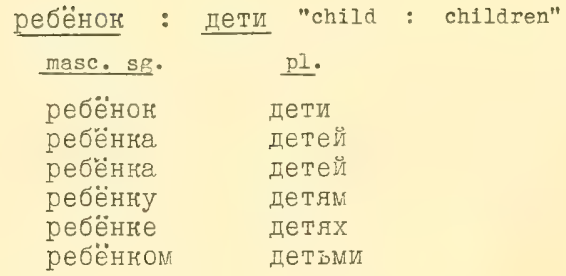

дочери
дочерей
дочерей
дочерям
дочерях
дочерьми

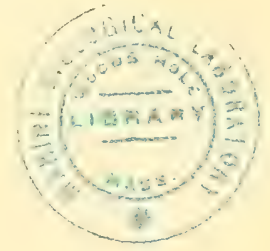

$\quad$ fem. pl.
матери
матерей
матерей
матерлм
матерлх
матерями

neut, ol.

имена

имена

пмён

именам

именах

именами времена
времена
времён
временам
временах
временами

*This word, which is used very frequently to introduce relative clauses, is, in form, a completely regular adjective.

**only used after numbers.

***0ther neuter nouns in this limited class are: бремя, Вымя, Знамл, Пламя, Племл, семя, стремя, темя. 
Russian Family Names in - ОВ/-еB, - ин $*$

\begin{tabular}{|c|c|c|c|c|c|c|}
\hline & mase: & fem. & pl. & masc. & fem. & pl. \\
\hline N & $\overline{\text { Петров }}$ & Петрова & Петровы & Пушкин & Пушкина & Пушкины \\
\hline A & Петрова & Петрову & Петровых & Пушкина & Пушкину & Пушкиных \\
\hline G & Петрова & Петровой & Петровых & Пушнина & Пушниной & Пушниных \\
\hline$D$ & Петрову & Петровой & Петровым & Пупнину & Пушниной & Пушкиным \\
\hline$P$ & Петрове & Петровой & Петровнх & Пушнине & Пушкиной & Пушниных \\
\hline & Петровьм & $\begin{array}{r}\text { Петровой, } \\
\text { Петровою }\end{array}$ & Петровыми & Пушкиным & $\begin{array}{l}\text { Пушниной, } \\
\text { Пушкиною }\end{array}$ & Пушкиными \\
\hline
\end{tabular}

$\underline{\text { Pronouns }}$

$\begin{array}{llllll} & \text { "I, me" } & \text { "уои" } & \text { "one's self" } & \text { "we, us" } & \text { "уои" } \\ \text { N } & \text { я } & \text { ты } & -- & \text { мн } & \text { вы } \\ \text { A } & \text { меня } & \text { тебя } & \text { себя } & \text { нас } & \text { вас } \\ \text { G } & \text { меня } & \text { тебя } & \text { себя } & \text { нас } & \text { вас } \\ \text { D } & \text { мне } & \text { тебе } & \text { себе } & \text { нам } & \text { вам } \\ \text { P } & \text { мне } & \text { тебе } & \text { себе } & \text { нас } & \text { вас } \\ \text { I } & \text { мной, } & \text { тобой, } & \text { собой, } & \text { нами } & \text { вами } \\ & \text { мною } & \text { тобою } & \text { собою } & & \end{array}$

\begin{tabular}{|c|c|c|c|c|}
\hline & "he, him,it" & "it" & "she,her,it" & "they, them" \\
\hline $\mathrm{N}$ & $\mathrm{OH}$ & $\mathrm{QHO}$ & \multirow{6}{*}{ 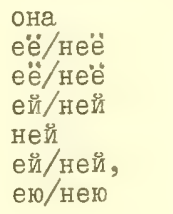 } & \multirow{6}{*}{$\begin{array}{l}\text { они } \\
\text { их/них } \\
\text { их/них } \\
\text { им/ним } \\
\text { ниХ } \\
\text { ими/ними }\end{array}$} \\
\hline A & \multicolumn{2}{|c|}{ ero/HeTo } & & \\
\hline G & \multicolumn{2}{|l|}{ ето/него } & & \\
\hline D & \multicolumn{2}{|l|}{ ему/нему } & & \\
\hline $\mathrm{P}$ & \multirow{2}{*}{\multicolumn{2}{|c|}{$\begin{array}{l}\text { Hëм } \\
\text { им/ ним }\end{array}$}} & & \\
\hline I & & & & \\
\hline & \multicolumn{2}{|l|}{ "who, whom" } & \multicolumn{2}{|l|}{ "what" } \\
\hline N & \multicolumn{2}{|l|}{ нто } & \multicolumn{2}{|l|}{ что } \\
\hline A & \multicolumn{2}{|l|}{ ROTO } & \multicolumn{2}{|l|}{ บто } \\
\hline G & \multicolumn{2}{|l|}{ FOTO } & \multicolumn{2}{|l|}{ чего } \\
\hline D & \multicolumn{2}{|l|}{ HOMY } & \multicolumn{2}{|l|}{ чемy } \\
\hline$P$ & \multicolumn{2}{|l|}{ HOM } & \multicolumn{2}{|l|}{ प'ẻM } \\
\hline$I$ & \multicolumn{2}{|l|}{ кем } & \multicolumn{2}{|l|}{ บeM } \\
\hline
\end{tabular}

Pronominal Adjectives

\begin{tabular}{|c|c|c|c|c|c|c|c|c|}
\hline $\mathrm{N}$ & $\begin{array}{l}\text { masc. } \\
\text { нашI }\end{array}$ & $\begin{array}{l}\text { neut. } \\
\text { Ha.me }\end{array}$ & $\begin{array}{l}\text { fem. } \\
\text { Hama }\end{array}$ & $\begin{array}{l}\text { pl. } \\
\text { наши }\end{array}$ & $\begin{array}{l}\text { masc. } \\
\text { BaII }\end{array}$ & $\begin{array}{l}\text { neut. } \\
\text { Baile }\end{array}$ & $\begin{array}{l}\text { fem. } \\
\text { ваma }\end{array}$ & $\begin{array}{c}\text { pl. } \\
\text { ваши }\end{array}$ \\
\hline A & $\begin{array}{l}\text { наш, } \\
\text { нашего }\end{array}$ & наше & нашу & $\begin{array}{l}\text { наши, } \\
\text { напих }\end{array}$ & $\begin{array}{l}\text { ваш, } \\
\text { вашего }\end{array}$ & Bame & вашу & $\begin{array}{l}\text { ваши, } \\
\text { ваших }\end{array}$ \\
\hline G & наш & & нашей & наших & ваш & & вашей & ваших \\
\hline D & HaII & & нашей & нашим & Bame & & вашей & вашим \\
\hline$P$ & наш & & нашей & наших & ваше & & вашей & ваших \\
\hline I & наш & & $\begin{array}{l}\text { нашей, } \\
\text { нашею }\end{array}$ & нашими & ваши & & $\begin{array}{r}\text { вашей, } \\
\text { вапею }\end{array}$ & вашими \\
\hline
\end{tabular}

\footnotetext{
*Russian famlly names are, like other nouns, characterized by gender distinction. Thus, the Russian names for husband and wife, brother and sister, etc., would vary according to the masc.-fen. pattern above. The plural, however, makes no distinction.
} 
MOLi,$*$. . "my"

\begin{tabular}{|c|c|c|c|}
\hline $\mathbb{N}$ & $\begin{array}{ll}\text { masc. } & \text { neut. } \\
\text { MоЙ } & \text { моё }\end{array}$ & $\begin{array}{l}\text { fem. } \\
\text { MOr }\end{array}$ & $\begin{array}{l}\text { pl. } \\
\text { мои }\end{array}$ \\
\hline A & $\begin{array}{l}\text { мой, моё } \\
\text { моего }\end{array}$ & мою & $\begin{array}{l}\text { Mon, } \\
\text { MoIx }\end{array}$ \\
\hline G & моето & моей & моих \\
\hline D & моemy & моeй & моим \\
\hline$P$ & моём & моей & моих \\
\hline I & моим & $\begin{array}{l}\text { Moей, } \\
\text { моею }\end{array}$ & моими \\
\hline
\end{tabular}

ЭTOT "this"

\begin{tabular}{|c|c|c|c|}
\hline ЭТОT & & эта & эти \\
\hline $\begin{array}{l}\text { Өтот, } \\
\text { ӨтоГо }\end{array}$ & & эту & $\begin{array}{l}\text { эти, } \\
\text { әтих }\end{array}$ \\
\hline 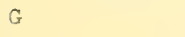 & этого & этоЙ & этих \\
\hline D & этому & этоЙ & Этим \\
\hline P & Этом & Этой & этих \\
\hline I & ә тим & $\begin{array}{r}\text { ӨTOH, } \\
\text { ЭTOF }\end{array}$ & этими \\
\hline
\end{tabular}

весь/BC- "all, the whole"

cam

$\begin{array}{cccc}\text { весь } & \text { всё } & \text { вся } & \text { все } \\ \text { весь, } & \text { всё } & \text { всп } & \begin{array}{c}\text { все, } \\ \text { всех }\end{array} \\ \text { всего } & & & \text { всей } \\ \text { всего } & \text { всей } & \text { всем } \\ \text { всему } & \text { всей } & \text { всех } \\ \text { всём } & \text { всей } & \text { всех } \\ \text { всем } & \text { всей, } & \text { всеми } \\ & \text { всею }\end{array}$

"self, him-/her-/it- self"

\begin{tabular}{|c|c|c|c|c|}
\hline cam & & camó & camá & са́ми \\
\hline $\begin{array}{l}\text { cam, } \\
\text { самого́ }\end{array}$ & & само & $\begin{array}{l}\text { camoë } \\
\text { /camý }\end{array}$ & $\begin{array}{l}\text { самй, } \\
\text { сами́х }\end{array}$ \\
\hline - & caMoTó & & camóĭ & самих \\
\hline D & самомý & & Camoin & сами́м \\
\hline$P$ & самóm & & самой & camin $\mathrm{x}$ \\
\hline I & сами́м & & $\begin{array}{l}\text { самой, } \\
\text { само́ю }\end{array}$ & самйи \\
\hline
\end{tabular}

CBOII, ... "one's own"

\begin{tabular}{|c|c|c|c|}
\hline & neut. & fem. & \\
\hline СвОЙ & CBÖ̈ & CBOA & Свои \\
\hline $\begin{array}{l}\text { свой, } \\
\text { своето }\end{array}$ & Сво $\mathrm{e}^{\circ}$ & СВОӊ & $\begin{array}{l}\text { СВОИ, } \\
\text { СВОИХ }\end{array}$ \\
\hline СBO & его & своей & своих \\
\hline СBO & ему & свое甪 & своим \\
\hline сво & & своей & своих \\
\hline CBO & & $\begin{array}{l}\text { своей, } \\
\text { своею }\end{array}$ & СВОИМИ \\
\hline
\end{tabular}

TOT "that"

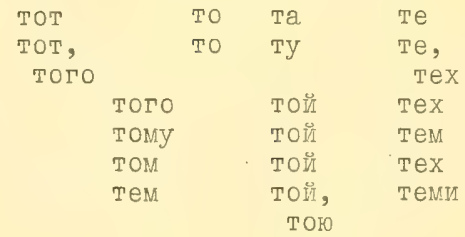

чей/чь- " "whose?"

\begin{tabular}{|c|c|c|c|}
\hline $\begin{array}{l}\text { чей } \\
\text { чей, } \\
\text { чьего }\end{array}$ & & $\begin{array}{l}\text { ЧЬЯ } \\
\text { ЧЬЮ }\end{array}$ & $\begin{array}{l}\text { Чьи } \\
\text { ЧьИ, } \\
\text { чьИХ }\end{array}$ \\
\hline & чьего & Чธeй & Чьих \\
\hline & чьему & чьей & Ч $\mathrm{J} / \mathrm{MM}$ \\
\hline & чЬём & чьей & ЧЬाIX \\
\hline & чьИМ & $\begin{array}{r}\text { чьей, } \\
\text { чьею }\end{array}$ & ЧьИми \\
\hline
\end{tabular}

самый ** "same, the very same, most"

* Tвой, ... "your[informal]" is declined like MOL̆ and CBOh.

** This adjective, which is often used in Russian to express a superlative degree (page 20), is a regular adjective; its forms are given here to contrast with the similar appearing forms of cam. 


\section{NUMBERS}

The various case forms of the cardinal numbers are listed below, with the exception of the declensions for numbers 1 to 4 , which appear on the following page. The Russian words for the ordinals("first", "second", etc.) are regular adjectives and are listed as such in any dictionary, e.g. первый(первое, первая...), "first".

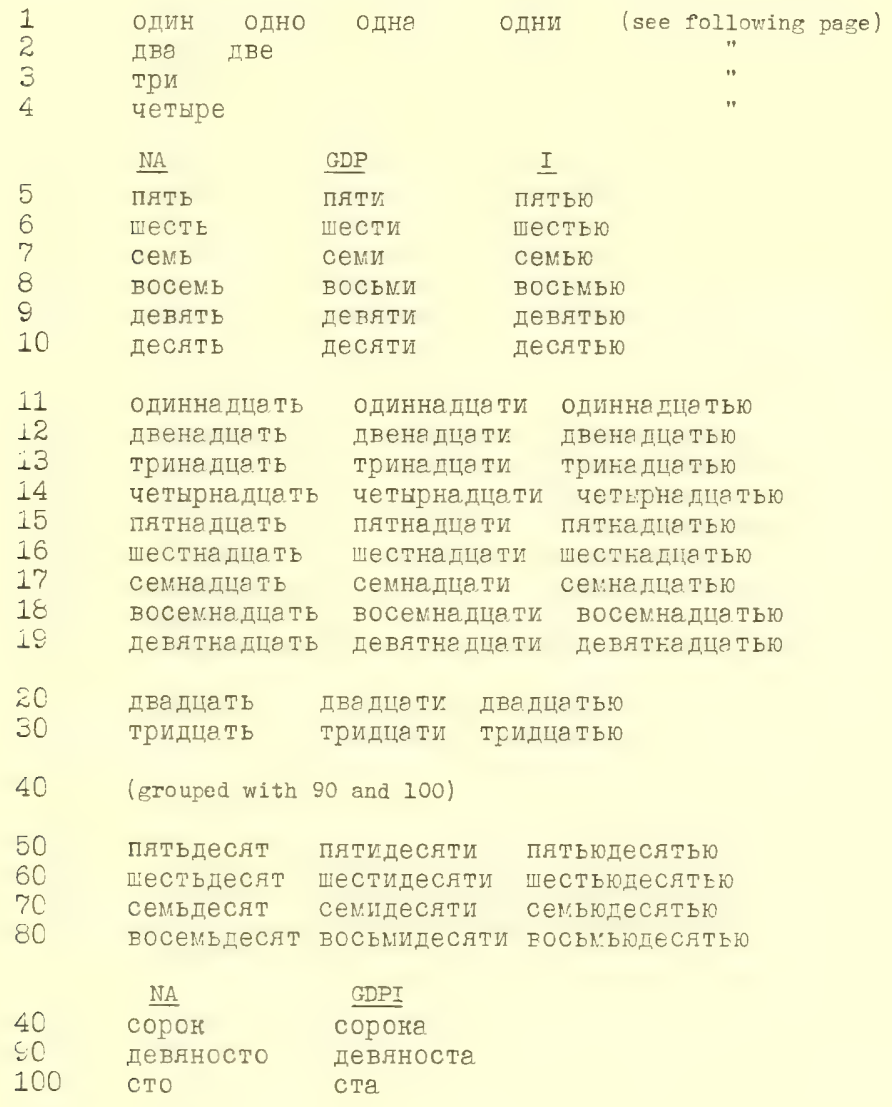

\begin{tabular}{|c|c|c|c|c|}
\hline & NA & $\underline{G}$ & $\underline{D}$ & $\underline{P}$ \\
\hline $2 \mathrm{CC}$ & пвести & ДВУХCOT & двумстам & двухстах \\
\hline & триста & трёхсот & трёмстам & трехстах \\
\hline & четыреста & четырёхсот & чет ирёмстам & четырёхстах \\
\hline & ПЯТБСОT & пятисот & пятистам & пятистах \\
\hline & шестьсот & Нестисот & шестистем & шестистах \\
\hline & семьсот & семисот & семистам & семистах \\
\hline & BOCEMbCOT & ВоСьмИСот & ВОСБNИСТАМ & ВосьмистеX \\
\hline & девЯтьсот & девятисот & девятистам & Іевятиствх \\
\hline
\end{tabular}

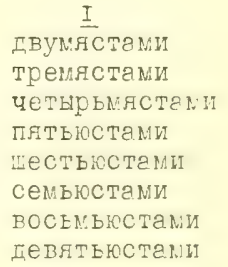


1,000 тысяча (declined like a fem. noun)

2,000 две тисячи

5,000 пять тысяч

1,000,000 миллион (declined like a masc. noun)

один/одн - "оne"

masc.

ОДИн

один, ОДНОГО

ОдНОГО

ОДНОМУ

О ДНОМ

ОпНим

\begin{tabular}{|c|c|}
\hline fem. & pl. \\
\hline одна & Одни \\
\hline Одну & $\begin{array}{l}\text { одни, } \\
\text { одних }\end{array}$ \\
\hline ОДНОЙ & одних \\
\hline одной & одним \\
\hline Одной & ОДниХ \\
\hline $\begin{array}{l}\text { ОДНОЙ, } \\
\text { ОДНОЮ }\end{array}$ & ОДНИМИ \\
\hline
\end{tabular}

$\begin{array}{cc}\text { оба, обе } & \text { "both" } \\ \text { masc./neut. } & \text { fem. } \\ \text { оба } & \text { обе } \\ \text { оба, } & \text { обе, } \\ \text { обсих } & \text { обеих } \\ \text { обоих } & \text { обеих } \\ \text { обоим } & \text { обеим } \\ \text { ообоих } & \text { обеих } \\ \text { обоими } & \text { обеими }\end{array}$

три "three"

четнре "four"

четыре

четыре, четырёх

четырёх

четырём

четырё

четырьмя 


\section{REVIEW OF VERB FORMS}

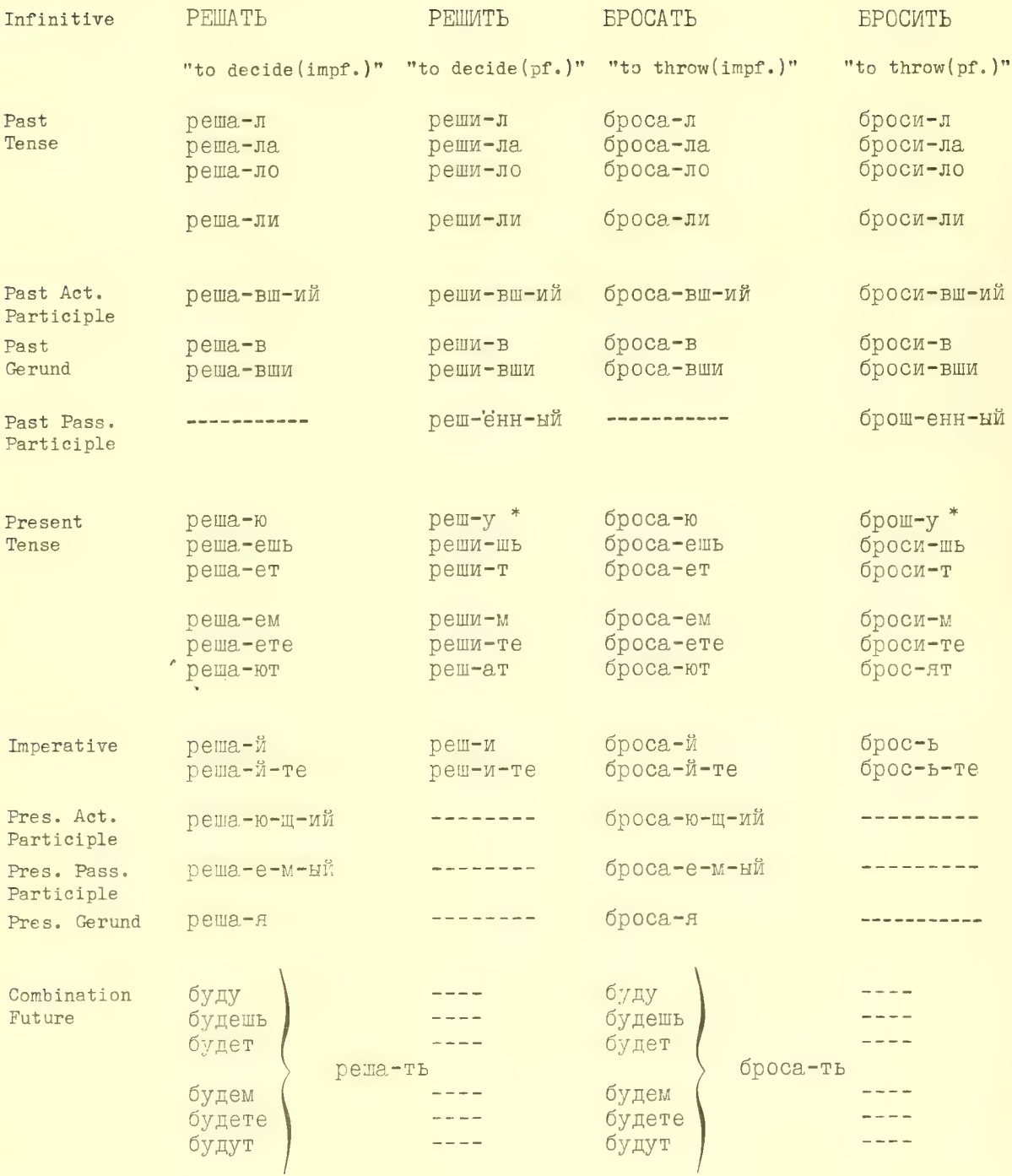

\footnotetext{
* Future meaning: I shall decide, you will decide, etc.; I shall throw, you will throw, etc.
} 
The Verb идти/-йти, "to go"

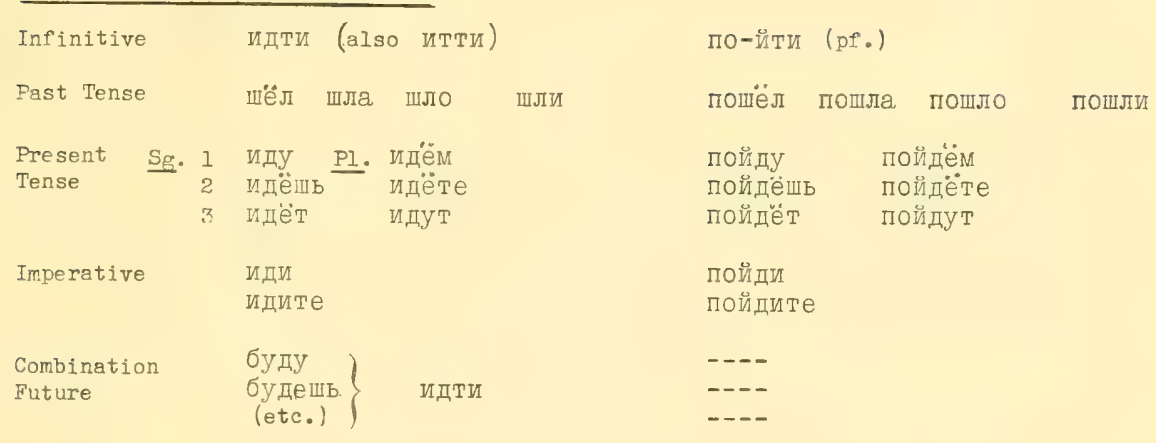

\section{Four Irregular Verbs}

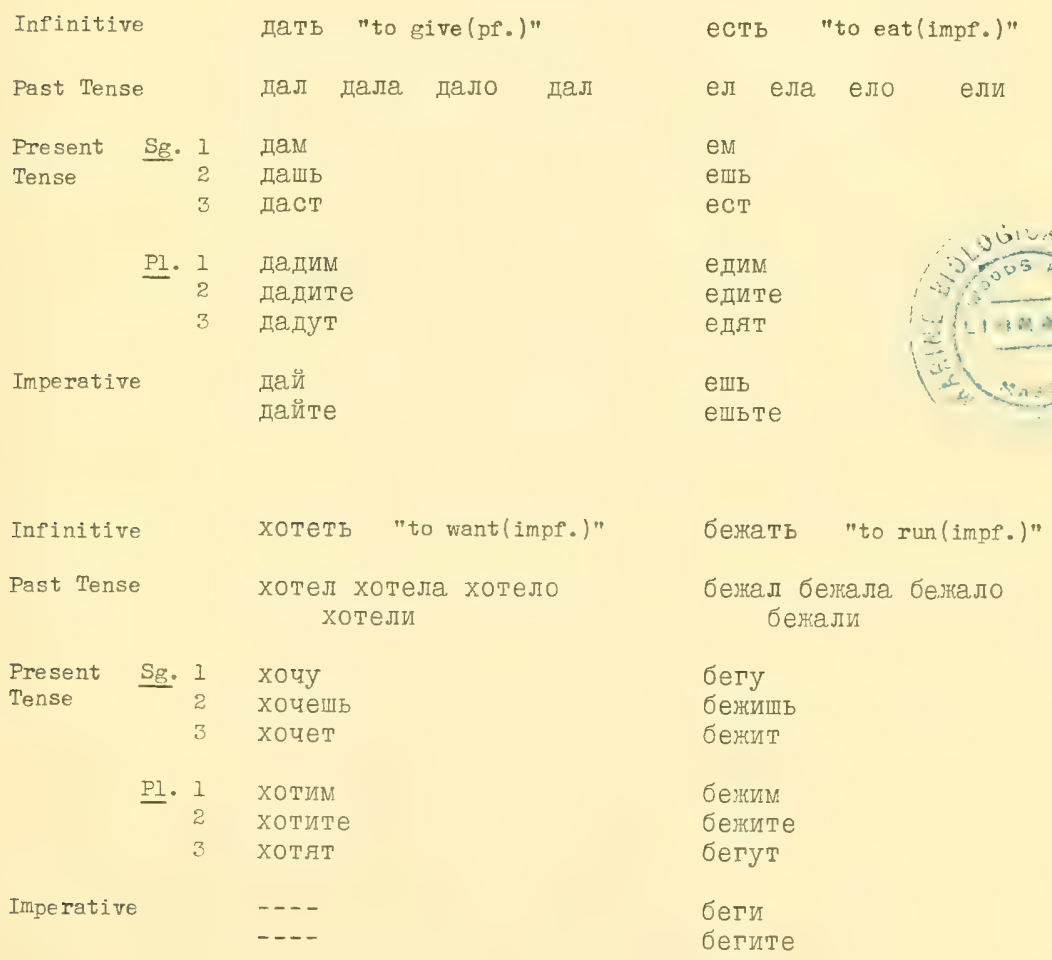




\section{Present Active Participles - Some Examples}

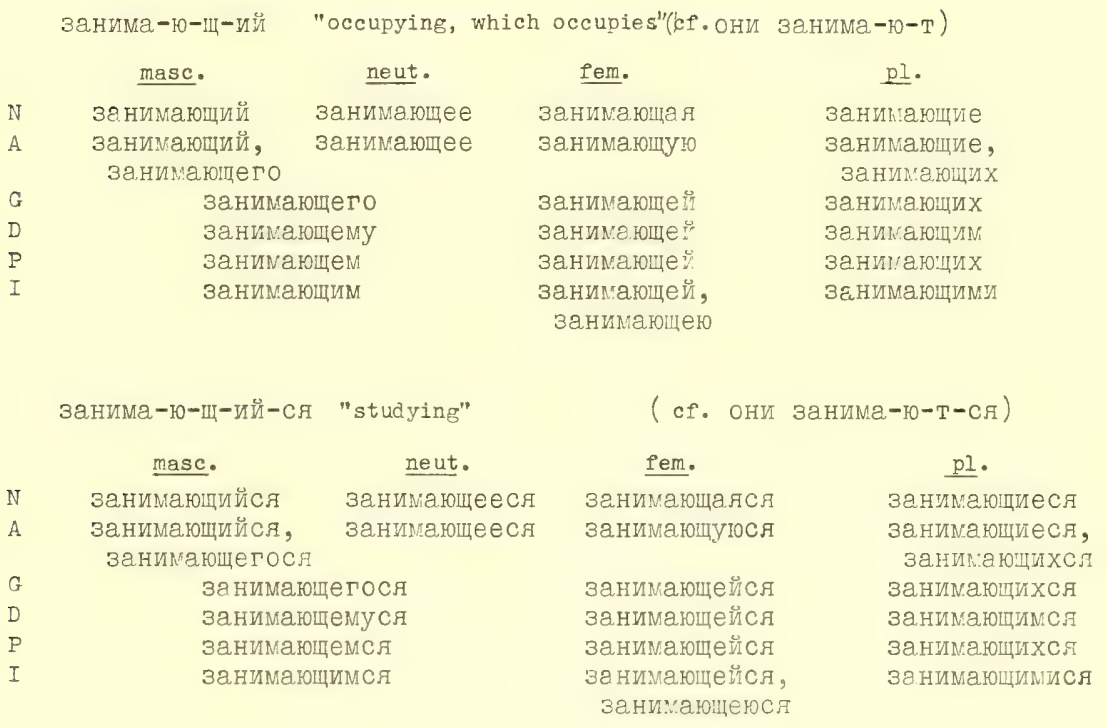

Other examples(in $\mathrm{N}$-sg. ) are:

$$
\begin{array}{lll}
\text { идущии } & \text { "going" } & (\text { сf.они идут }) \\
\text { стоящй "standing" } & (\text { сf.они стоят) } \\
\text { нричапий "shouting" } & (\text { сf.они причат })
\end{array}
$$

\section{Present Passive Participles - Some Examples}

\begin{tabular}{|c|c|c|}
\hline приностмнй & "being brought" & 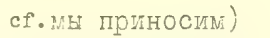 \\
\hline внсушива емии & "being eveporated" & (f. ME BHCучиваем) \\
\hline просимый & "being requested" & cf.N: прослM) \\
\hline исполь зуемшй & "being used" & сf.जн используем) \\
\hline
\end{tabular}

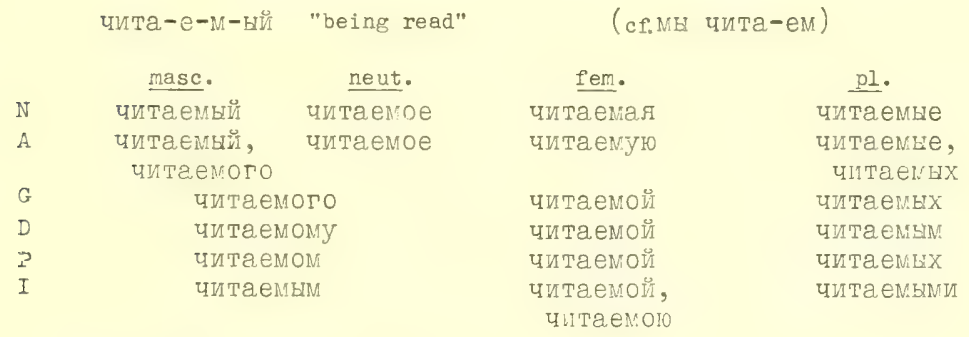

other examples(in $\mathrm{N}$-sg.) are: 


\section{Past Active Participles - Some Examples}

$$
\text { занима-вШ-й "having occupied" }
$$

$\begin{array}{ll}\text { занимавший } & \text { занимавшее } \\ \text { занимавшй, } & \text { занимавшее } \\ \text { занимавшего } & \end{array}$

masc.

занимавшего

занимавшему

занимавшем

занима вшим

neut.

N

G

D

I

(сf.ванима-ть)
fет.
занимавшая
занимавшую
занимавшей
занимавшей
занимавшей
занимавшей,
занимавшею

(сf.занима-ть)

pl.

занимавиие

занимавшие, занимавших ванимавших занимавщим занимавших занимавшими
32нима-вII-IL

masc.

neut.

N

A

G

D

P

I

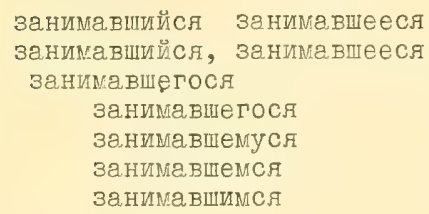

(cf. занима-ть-ся)

fem.

занимавшаяся

занимавшуюся

занимавнейся

занимавшейся

занимавшейся

занимавшейся,

занимавшеюс pl.

занимавшиеся занимавшиеся, занимавшихся занимавшихся занима вшимс 9 занимавшихся занимавштмися

Some other examples(in $\mathbb{N}$-sg.) are:

$\begin{array}{lll}\text { построившй } & \text { "having built" } & \text { (сf. постропть) } \\ \text { принёсшй } & \text { "having brought" } & \text { (сf. принести) } \\ \text { имевшй } & \text { "having had" } & \text { (сf. иметь) }\end{array}$

\section{Past Passive Participles - Some Examples}

$$
\begin{array}{cr}
\text { написа-нн-सili } & \text { "written" } \\
\text { masc. } & \text { neut. }
\end{array}
$$

$$
\text { написанный }
$$$$
\text { написанного }
$$

написанного

написанному

неписанном

написанним$$
\text { написанный, }
$$

написанное

написанное

G

D

I (cf.написа-ть)

fem.

написанная

написанную

написанної

написанной

написанной

написанной,

написанною pl.

написанные написанные, написанных написанных написанным написанных нагисанньми

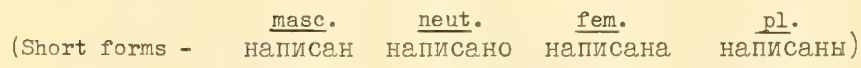

Some other examples(in $\mathrm{N}-\mathrm{sg}$.) are:

$\begin{array}{ll}\text { построенннй } & \text { "built" } \\ \text { принесённый } & \text { "brought" } \\ \text { понрытый } & \text { "covered" }\end{array}$

(сг.построить)

(сг.принести)

(сf.понрнть) 
This section represents an attempt to reduce a body of grammatical lore to lists of easily identifiable grammatical facts. It is basically a "finder" section, to which the student may turn for rapid identification of Russian forms.

Only a small number of the forms contained in the following lists are actually "irregular" in the traditional sense; most of the forms are regular and thus predictable, but only within the framework of limited patterns. For example, a masculine form of the past tense would normally(i.e. in the majority of instances) be a form like читал "he read/was reading", though a form such as MOr "he was able", is explainable. Explanations and their retention by the student are, however, possible only when the learning process is spread over a period of time much longer than that available to the average scientist. It is thus much more reasonable to expect the scientist-student to know that читал is the masc. form, past tense, of читать but to allow him to treat Mог as a vocabulary item, identified and explained on an alphabetized list.

This reference section contains the following compilations:

\section{Noun Forms}

II Comparative Adverbs

III Determining Infinitives from Present Tense Forms

a) Present tense forms in -e-

b) Present tense forms in $-И-$

IV Identifying Past Tense Forms and Determining Infinitives

V Identifying Past Active Participles and Past Gerunds; Determining Infinitives

VI Identifying Past Passive Participles and Determining Infinitives

VII Index of Signals

- Noun Endings

- Adjective Endings

- Noun and Adjective Endings

- Verb Endings

- Endings of Participles and Gerunds

VIII Standard Abbreviations in Russian

\section{Noun Forms}

The following list identifies particular noun forms(e.g. ядеp,G-pl. of ядро) and also indicates stem variations between singular and plural( $\overline{\mathrm{e} . \mathrm{g}}$. N-sg. ГосподиH : $\mathrm{N}-\mathrm{pl}$. Господа or between the N-sg. and all other case forms(e.g. N-sg. I0б:G-sg. Alphabetic order will be followed, with this exception: the $\mathrm{N}-\mathrm{sg}$. form with its English meaning will come first in a series of case-related forms.

$\begin{array}{llll}\text { англича́нин } & \text { "Englishman" } & \text { брат } & \text { "brother" } \\ \text { англича́н } & \text { AG-pl. } & \text { братьев } & \text { AG-pl. } \\ \text { англича́нам } & \text { D-pl. } & \text { братья } & \text { N-pl. } \\ \text { англича́не } & \text { N-pl. } & \text { бремя (nөut.) "burden" }\end{array}$

$\begin{array}{ll}\text { бременем } & \text { I-sg. } \\ \text { бремени } & \text { GDP-sg. } \\ \text { время (neut.) } & \text { "time" } \\ \text { временá } & \text { NA-pl. }\end{array}$




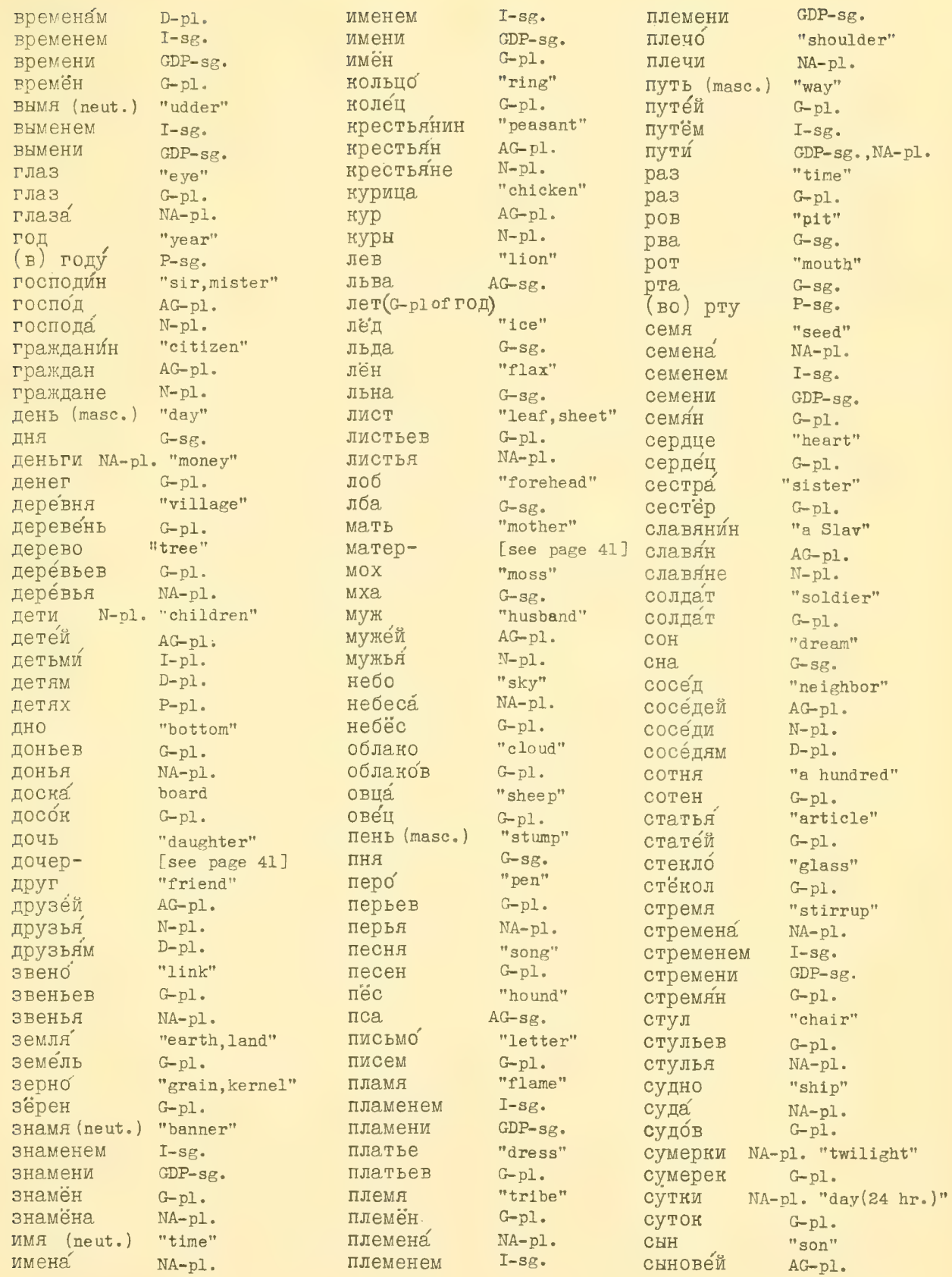




\begin{tabular}{|c|c|c|c|c|c|}
\hline СЫнОВБЯ' & $\mathrm{N}-\mathrm{pl}$ & уровень (masc.) & ) "level" & челове́к & "person" \\
\hline телёнок & "calf" & уровня & G-sg. & челове́ & G-pl.[after 5...] \\
\hline телк्ят - & [see page 14] & $\mathrm{yxo}$ & "ear" & число́ & "number" \\
\hline темя (neut.) & "top of head" & уша́м & D-pl. & чисел! & $\mathrm{G}-\mathrm{pl}$ \\
\hline теменем & $\mathrm{I}-\mathrm{sg}$ & уще́й & $\mathrm{G}-\mathrm{pl}$ & чудо & "marvel" \\
\hline темени & $G D P-3 \xi$ & уши & $\mathrm{NA}-\mathrm{pl}$ & чуде́с & G-pl. \\
\hline угол & "corner, angle" & хозяин & "host, owner" & чупеса́ & $\mathrm{NA}-\mathrm{pl}$ \\
\hline угла́ , & $G-s g$ & хозя́ев & $\mathrm{AG}-\mathrm{pl}$ & Шов & "seam" \\
\hline (в) углу & $\mathrm{P}-\mathrm{sg}$ & хозяева & N-pl. & пва & $\mathrm{G}-\mathrm{sg}$ \\
\hline уголь (masc.) & "coal" & цвет & "color" & япро & "nucleus" \\
\hline угля & G-sg. & цветध́ & $\mathrm{NA}-\mathrm{pl}$ & япер, & G-pl. \\
\hline узел & "knot, network" & цвето́́ & "flower" & ศทัцо & "egg" \\
\hline узла & $G-S B$ & цвети́ & NA $-\mathrm{pl}$ & яйц & G-pl. \\
\hline
\end{tabular}

\section{Comparative Adverbs}

\begin{tabular}{|c|c|c|c|c|c|}
\hline ближе & ( близний) & "closer" & лучше & ( хоро́ший) & "better" \\
\hline бога́че & (бога́тый) & "richer" & мельче & (мелкий) & "finer" \\
\hline более & & "more, -er" & менее & & "less" \\
\hline больше & ( большо́й & "bigger,more" & меньше & (маленький) & "less, fewer" \\
\hline Bume & ( внсо́ний & "higher, above" & моло́же & (молодо́й) & "yourger" \\
\hline вязче & ( вязкий) & "more viscous" & мятче & (мягКИй) & "softer" \\
\hline глаже & (г ла,дний) & "smoother" & ниже & низиий & "Iower, below" \\
\hline глубже & (глубо́кий) & "deeper" & плосче & (ПлоскиЙ & "flatter" \\
\hline горче & (горький) & "more bitter" & позже & (ПозДнИЙ & "later" \\
\hline громче & (громкий) & "louder" & проще & (просто́й & "more common" \\
\hline гуще & (густо́й) & "thicker" & раньше & ранний) & "earlier" \\
\hline дальше & (далёкий) & "farther" & реже & редкий & "rarer" \\
\hline деше́вле & ( дешёвый & "cheaper" & резче & резни & "sharper" \\
\hline дольше & (долгий) & "Ionger" & слаще & (слапкий) & "sweeter" \\
\hline доро́не & (дорого́й) & "dearer" & старше & (старый & "older" \\
\hline епче & (едкий) & "more caustic" & строне & строги & "stricter" \\
\hline भа.Јіьче & (жалкий) & "more pitiful" & твёрже & (твёрдый) & "firmer" \\
\hline жарче & (жаркий) & "hotter" & тише & $1.1 / 1 \times 1 / 1 /$ & "quieter" \\
\hline жёстие & (жёстний) & "harder, rougher" & толще & (толстьй) & "thicker" \\
\hline жиже & (жидний) & "more Iluid, thinner" & тоньile & ( тонкий) & "thinner" \\
\hline нороч́e & ( норо́тний) & "silorter" & yжe & (узкий) & "more narrow" \\
\hline нратче & (краткий) & "shorter" & хуже & (Плохо́̆ & "worse" \\
\hline нрепче & (крелкий) & "stronger" & чаще & ( частый & "more often" \\
\hline пруче & ( круто́й) & "tighter,more steeply & чище & (чистый) & "cleaner" \\
\hline легче & ( лёгний) & "lighter,easier" & шире & ( пиро́кий) & "wider" \\
\hline & & & яpue & ( яртий) & "brighter" \\
\hline
\end{tabular}

\footnotetext{
*For the usage of these forms consult page 20. Additional meanings may be obtalned by looking up the related adjective(in parentheses above) in a dictionary.
} 
Preliminary Remarks f $\mathrm{r}$ Lists III, IV, V and VI

In coping with forms of Russian verbs the beginning student finds himself at a great disadvantage because of the economy of statement typical of the usual dictionary. If the student is able to identify a particular form as a $3 \mathrm{rd}$. sg., present tense, for example, and if he is able to determine the appropriate infinitive, then the dictionary will supply the general verbal meaning; if the verb form in question is such that its relationship to an infinitive is not obvious, the average dictionary will then be of little, if any, help.

There are hundreds of Russian verbs which do not have an "obvious" relationship between the infinitive and the other forms. This number can be great ly reduced, if one "strips away" the verbal prefixes and considers only the underlying simple verb. If, for example, a student is trying to identify the past form произвёл, he can remove the prefixes про and из. A glance at the past tense forms on List IV will show the student that вё is the masc. form of the infinitive вести and he may then go to the dictionary and determine the meaning of про-из-вести.

The following simple procedure is basic to the use of the lists in identifying present tense forms(List III), past tense forms(List IV), past active participles and past gerunds (ListV), and past passive participles(List VI).

1. Detach the reflexive ending $(-\mathrm{CA} /-\mathrm{Cb})$, if it occurs on the form in question.

2. Detach any of the prefixes(listed below) which may enter into the constitution of the form.

3. Locate the simplex on the appropriate list and note the infinitive form listed after it.

4. Attach the prefix(es) and the reflexive ending, if required, to the infinitive. Occasionally the resultant infinitive uses a prefix variant, as noted below.

5. Obtain the meaning for the derived infinitive from the dictionary.

Prefixes
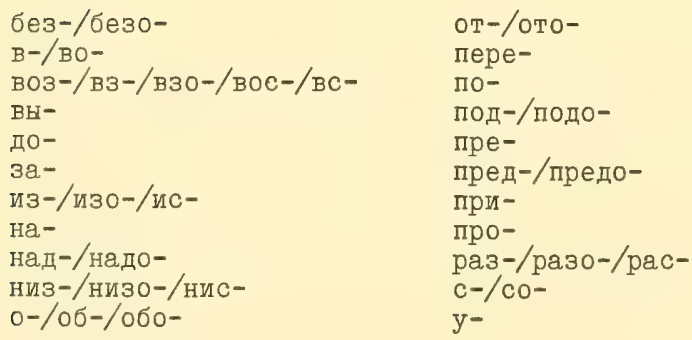
III Determining Infinitives from Present Tense Forms

a) Present tense forms in -e- ; $3 \mathrm{rd}$. pl. forms in $y / \underline{10}$. The $3 \mathrm{rd}$. sg. and the $3 \mathrm{rd}$. pl. forms will represent the six present forms; the appropriate infinitive is listed after the colon.

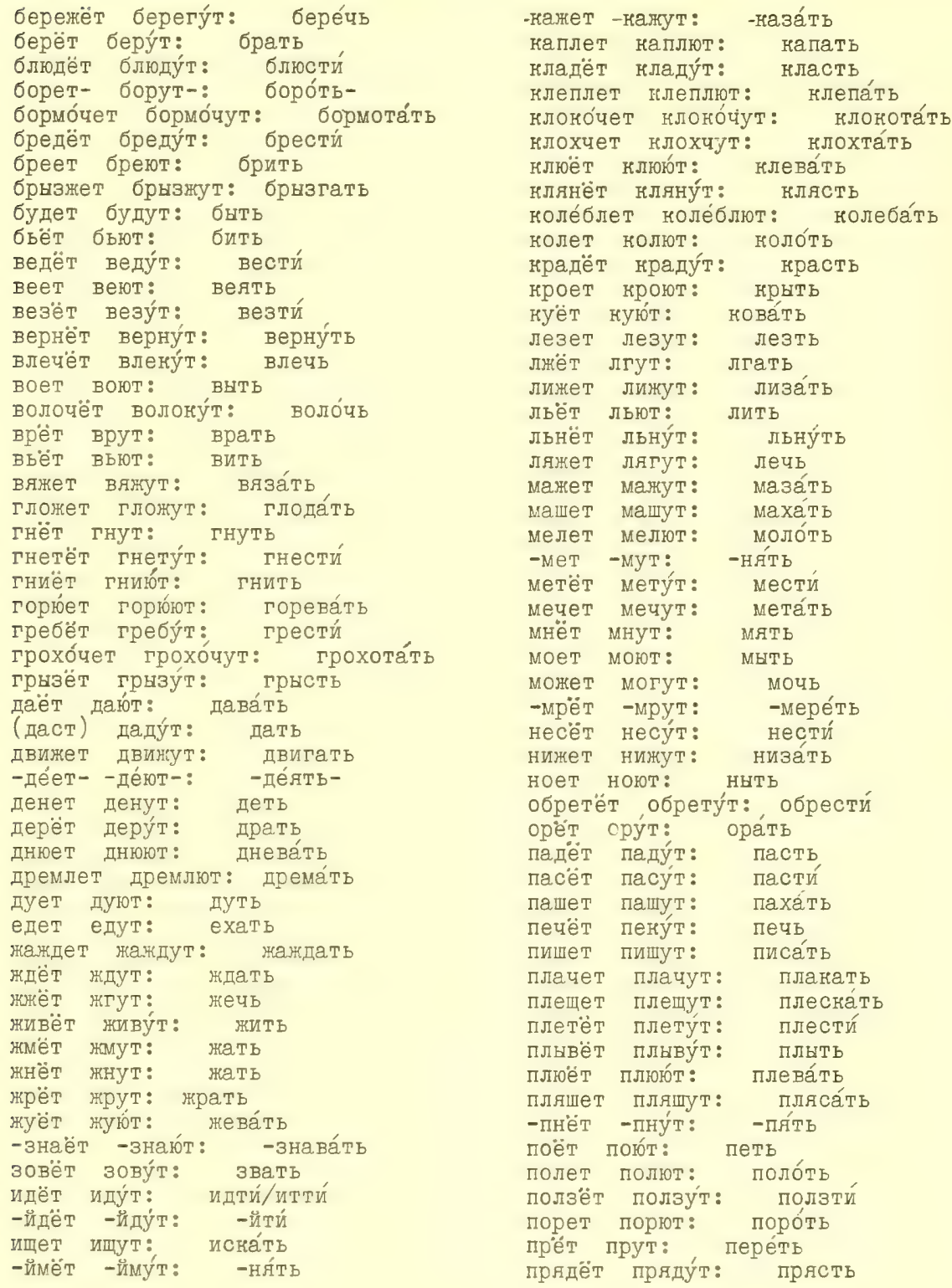


-пряжеет -прягу́т: -пря́чь прячет прячут: прятать пьёт пьют: пить растёт расту́т: расти́ рвёт рвут: рвать ревёт реву́т: реве́ть режет режут: резќть -речёт- -рену́т-: -ре́чьржёт ржут: рнать роет роют: рНть

свищет свищут: свиста́ть сечёт сену́т: сечь

снанет снажут: сназать

сначет сначут: снана́ть

скребёт снребу́т: спрести́

сливёт слнвутт: слыть

смеет смеют: сметь

смеёт- смею́т-: смея́ть-

снимет снимут: снять

снуёт сную́т: снова́ть

сосёт сосу́т: соса́ть

-стаёт-стаю́т: -става́ть

станет станут: стать

стелет стелют: стлать

стережёт стерегу́т: стере́чь стонет стонут: стонать

стринёт стригу́т: стричь

суёт сую́т: сова́тв

сыплет сыплют: сыпать

сядет сядут: сесть

-таёт -тают: -тава́ть

течёт текут: течь

тешет тешут: теса́ть

ткёт ткут: тнать

толчёт толну́т: толо́чь

топчет топчут: топта́ть

треплет треплют: трепа́ть

трёт трут: тере́ть

трясёт трясут : трясти́

хлещет хлещут: хлеста́ть

хлопо́чет хлопо́чут: хлопота́ть

хочет (хоти́т): хотеть

цветёт цвету́т: цвести́

чешет чешут: чеса́ть

-чнёт -ину́т: -иа́ть

-чтёт -чту́т: -че́сть

шепчет шепчут: шепта́ть

шлёт шлют: слать

щеплет щеплют: щепа́ть

-ьмёт -ьму́т: -и́ть

III b) Present tense forms in $-И-, 3 \mathrm{rd}$. pl. forms in $\mathrm{a} / \mathrm{g}$.

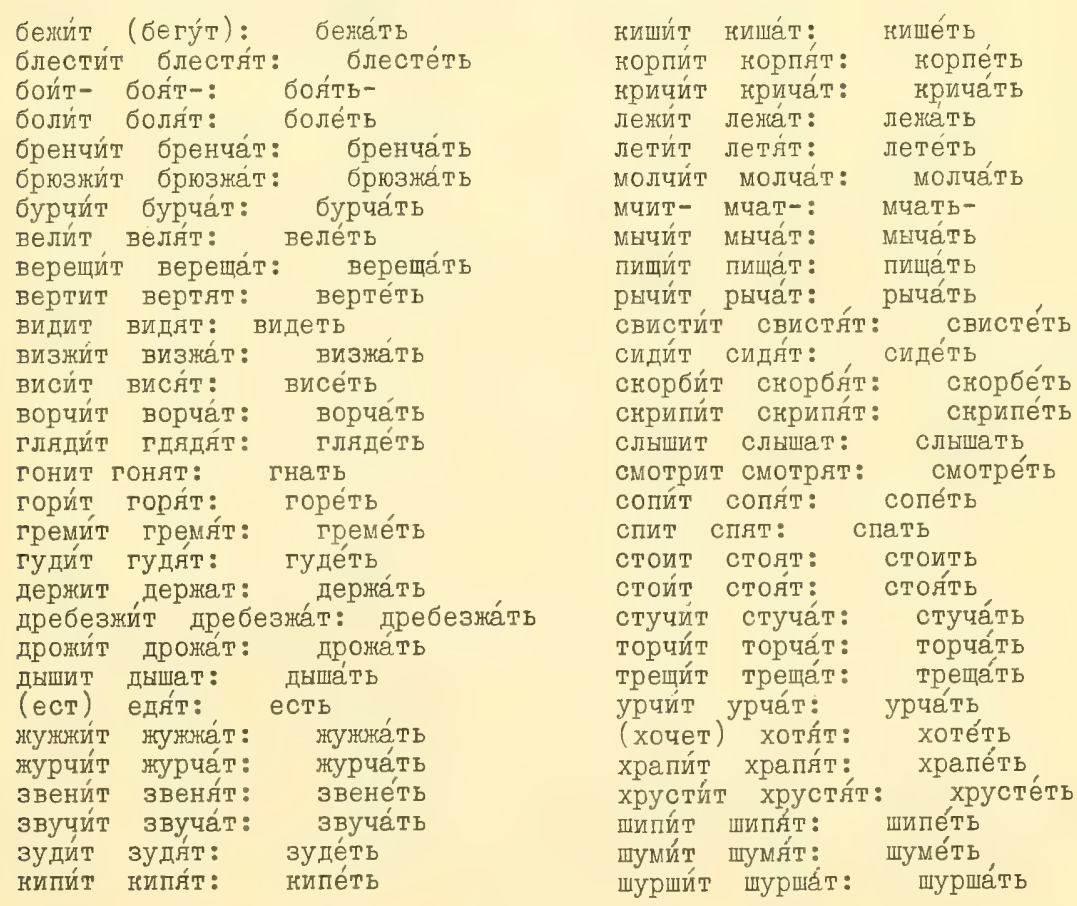


IV Identifying Past Tense Forms and Determining Infinitives

\begin{tabular}{|c|c|c|c|c|}
\hline masc. & fem. & neut. & pl. (all genders) & infinitive \\
\hline берёг & берегла́ & берегло́ & берегли́ & бере́чь \\
\hline блюл & блюла́ & блюло́ & блюли́ & блюсти́ \\
\hline брёл & брела' & брело & брели́ & брести́ \\
\hline вёз & везла́ & везло́ & везли́ & везти́ \\
\hline вёл & вела́ & вело́ & вели́ & вести́ \\
\hline влёк & влекла́ & влекло́ & влекли́ & влечь \\
\hline * - $\mathrm{BHK}$ & -внкла & -вынло & -вынли & -ви́ннуть \\
\hline * гас & гасла & гасло & гасли & гаснуть \\
\hline грёб & гребла' & гребло́ & гребли́ & грестй \\
\hline грнз & грнзла & грнзло & грнзли & грысть \\
\hline eת & ела & ело & ели & есть \\
\hline жёг & жгла & ЖГЛО & жГЛИ & жечь \\
\hline * исче́з & исче́зла & исче́зло & исче́зли & исче́знуть \\
\hline клал & клала & клало & нлали & нласть \\
\hline КЛЯЛ & иляла́ & нляло́ & кляли́ & КЛЯсть \\
\hline кра.л & нрала & нрало & крали & красть \\
\hline лё̈г & легла́ & летло́ & легли́ & лечь \\
\hline лез & лезла & лезло & лезли & лезть \\
\hline мёл & мела́ & мело́ & мели́ & мести́ \\
\hline * мёрз & мёрзла & меррзло & мёрзли & мёрзнуть \\
\hline MOT & могла́ & MOTJо́ & могли́ & МОчь \\
\hline Hëc & несла́ & несло́, & несли́ & нести́ \\
\hline обліён & облекла' & облекло́ & обленли́ & обле́чь, \\
\hline обрёл & обрела́ & обрело' & ои́рели́ & обрести́ \\
\hline остерёг & остерегла́ & остерегло́ & остереглй & остере́чь \\
\hline па.л & пала & пало & пали & пасть \\
\hline пас & пасла́ & пасло' & пасли́ & пасти́ \\
\hline ПёK & пенла́ & пенло́ & пекли́ & печь \\
\hline плёл & плела́ & плело́ & плели́ & плести́ \\
\hline полз & ползла́ & ползло & ползли́ & ползти́ \\
\hline пренебрёг & пренебрегла́ & пренебрегло́ & пренебрегли́ & пренебре́чь \\
\hline -пряг & -прягла & -прягло́ & -пряглй & -прячь \\
\hline пря Л & пряла́ & пряло & пряли & прясть \\
\hline -për & - репла́ & -ренло́ & -реклй & -речь \\
\hline poc & росла́ & росло́ & росли́ & расти́ \\
\hline cek & секла & секло & секли & сечь \\
\hline сел & села, & село, & сели & сесть, \\
\hline скрёб & скребла́ & скребло́, & скребли́ & снрести́ \\
\hline стерёг & стерегла́ & стерегло́ & стерегли́ & стере́чь \\
\hline стриг & стригла & стригло & стригли & стричь \\
\hline$T \ddot{e}_{\mathrm{K}}$ & тенла́ & текло́ & тенли́ & течь \\
\hline тёp & тёрла, & те́рло & тёрли & тере́ть \\
\hline толо́к & толюла́ & ТОЛЕЛО́ & толюли́ & толо́чь \\
\hline тряс & трясла́ & трясло́ & трясли́ & трясти́ \\
\hline yмep & умерла́ & умерло́ & умерли́ & умере́ть \\
\hline цвёЛ & цвела́ & цвело́ & цвелй́ & цвести́ \\
\hline -чёл & -чла & -чло & -члли & -че́сть , \\
\hline щёл & шла, & шло & пли & идти/иттй, -йти \\
\hline -ши́б & -ши́бла & -щи́бло & -ши́бли & -шибить \\
\hline
\end{tabular}

\footnotetext{
* The few non-regular past forms not listed here are of this type, that is, their infinitives will have final-нуть.
} 
These two categories have a similar formation and so may be listed together. It should be remembered, however, that the participles may appear with adjective endings other than the masc. N-sg. ending used in the examples, while the gerunds, being adverbs, are non-varying. The reflexive ending for participles is always-CA, but always $-\underline{C} \mathrm{~B}$ for gerunds.

\begin{tabular}{|c|c|c|c|c|c|}
\hline Participles & Gerunds & Infinitives & Participles & Gerunds & $\underline{\text { Infinitives }}$ \\
\hline берёгший & берёгши & бере́чь & па сший & па.сии & пасти́ \\
\hline блюдший & блюдши & блюстй & пёкший & пёгши & печь \\
\hline вепщий & ведши & вести́ & п'ёрший & пёрши & пере́ть \\
\hline вёзший & вёзши & везти́ & плётший & плётши & плести́ \\
\hline В Јёеншй & Влёнши & влечь & ползший & ползши & ползти́ \\
\hline воло́кший & воло́кши & воло́чь & пренебрёгпий & пренебрёгши & пренебре́чь \\
\hline -вь́кший & -Ви́кши & -ви́кнуть & пряпний & прядши & прясть \\
\hline Гасший & гасши & гаснуть & -рёкший & -рёнши & -péub, \\
\hline гр’е́бший & грёбши & грести́́ & росший & росшиі & расти́ \\
\hline Грнзий & грнзши & грысть & севший & севши & сесть \\
\hline евпй: & евиц & есть & сеншиі & сенши & сечь, \\
\hline к лавший & нлавши & класть & снрё́бшй & скрёбши & скрести́ \\
\hline НлЯВшиИ & кЛя Вши & нл月сть & стерёгший & стерёгши & стере́чь \\
\hline кравший & кравши & красть & стригший & стригши & стричь \\
\hline лёгшй & лёгши & лечь & тёнший & тёкши & течь \\
\hline лезшиі & лезши & лезть & тёршуій & тёрши & тере́mb \\
\hline мётший & мётши & мести́ & толо́нший & толо́кши & толочь \\
\hline нёспй & нёсши & нести́ & трясший & трясши & трясти́ \\
\hline облёкший & облёкши & обле́чь & цветшиц & цветши & цвести́ \\
\hline обре́тший & обре́тши & обрести́ & -чётший & -чётши & -че́сть \\
\hline па вши й & павши & пасть & шедшй & шедши & ицти́, -йти́ \\
\hline па.дший & ---- & " & -шибший & -шибши & -шибитт \\
\hline
\end{tabular}

\section{Identifying Past Passive Participles and Determining Infinitives}

Since the past passive participle is such a frequent form, both in spoken and written Russian, great care should be taken in identifying it. One complicating circumstance is the fact that certain consonant changes(described on page 32 ) take place in this grammatical category. The examples below will be given in the masc., $\mathrm{N}-\mathrm{sg}$. form; remember that one $\mathrm{H}$ is dropped in the short forms; e.g., описанное : описано.

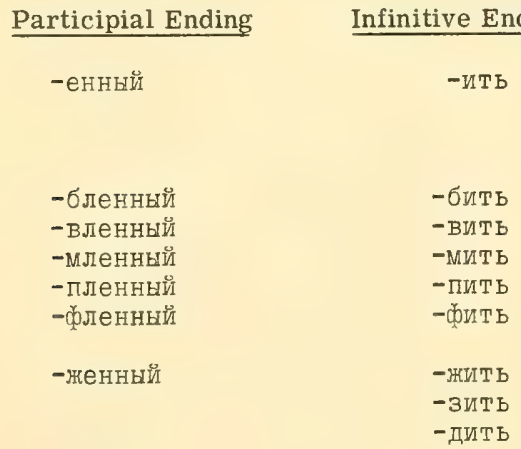

Examples

\begin{tabular}{|c|c|c|}
\hline вьбеленный & : & выбелить \\
\hline объяснённแЙ & : & ОбЪясни́т В \\
\hline сотворённий & : & сотворитт \\
\hline влюблённцй & : & Влюбйть \\
\hline давленный & : & павить \\
\hline норм Јенннй & : & норми́ть \\
\hline купленншй & : & купитть \\
\hline графлённый & : & граф̆йт \\
\hline заутю́женный & : & заутю́жить \\
\hline гружённнй & : & грузи́ть \\
\hline стуженний & : & студить \\
\hline
\end{tabular}




\begin{tabular}{|c|c|c|c|c|}
\hline Participial Ending & Infinitive Ending & Examp & ples & \\
\hline -આденный & -дить & утверждённый & & утверди́ть \\
\hline -ченный & $\begin{array}{l}\text {-чить } \\
\text {-тить }\end{array}$ & $\begin{array}{l}\text { полученный } \\
\text { уплаченный }\end{array}$ & : & $\begin{array}{l}\text { получи́ть } \\
\text { уплатитьь }\end{array}$ \\
\hline -шенный & $\begin{array}{l}- \text {-ить } \\
\text {-сить }\end{array}$ & $\begin{array}{l}\text { совершённый } \\
\text { изно́шенншй }\end{array}$ & : & $\begin{array}{l}\text { соверши́ть } \\
\text { износи́ть }\end{array}$ \\
\hline -щенный & $\begin{array}{l}\text {-щить } \\
\text {-тить }\end{array}$ & $\begin{array}{l}\text { намо́рщенншй } \\
\text { обращённый }\end{array}$ & : & $\begin{array}{l}\text { намо́рщить } \\
\text { обрати́ть }\end{array}$ \\
\hline
\end{tabular}

Not all past passive participles fall into the above "regular" patterns and thus the following two lists encompass the "non-regular" types.

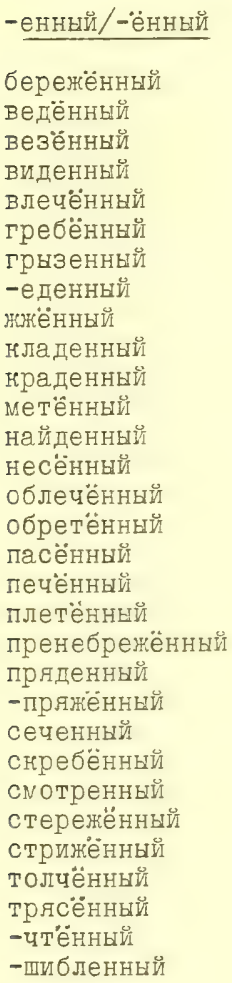

бере́чь
вести́́
везтй
видеть
влечь
грести́
грнзть
-есть
нечь
нласть
нрасть
мести́
найи́́
нести́
облечь
обрести́
пасти́
печь
плести́
пренебречь
прясть
-прнчь
сечь,
снрести́
смотре́ть
стере́чь
стричь
толочь,
трястй
-честь
-шибить

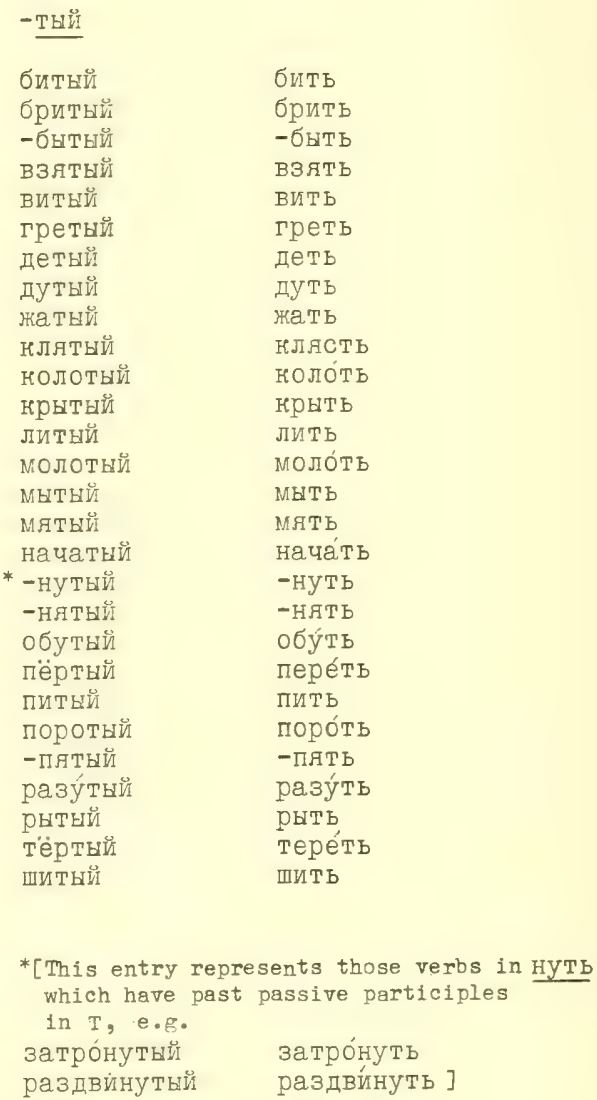


Index of Signals - Noun Endings

\begin{tabular}{|c|c|c|c|c|c|c|}
\hline \multirow[b]{3}{*}{-Zero* } & \multicolumn{3}{|c|}{ Singular } & \multicolumn{3}{|c|}{ Plural } \\
\hline & Masc. & Neut. & Fem. & Masc. & Neut. & Fem. \\
\hline & $\mathrm{NA}$ & & & $(G)^{* *}$ & G & G \\
\hline$-a$ & G & G & $\mathrm{N}$ & (NA) & NA. & \\
\hline-9 & $\bar{G}$ & G & $\mathrm{N}$ & (NA) & NA & \\
\hline-0 & & $\mathrm{NA}$ & & & & \\
\hline$-e$ & $\mathrm{P}$ & NAP & DP & (N) & & \\
\hline$-\ddot{e}$ & & NA & & & & \\
\hline$-\mathrm{H}$ & & & G & NA & & $\mathrm{NA}$ \\
\hline- I & $\mathrm{P}$ & P & GDP & NA & & NA \\
\hline$-y$ & $\mathrm{D}(\mathrm{P})$ & D & A & & & \\
\hline-10 & $D(P)$ & D & $\mathrm{A}$ & & & \\
\hline -Ью & & & I & & & \\
\hline$-\mathrm{OH}$ & & & $I$ & & & \\
\hline -ею & & & $I$ & & & \\
\hline -ёю & & & $\mathrm{I}$ & & & \\
\hline$-(n)-i$ & $\mathrm{~N}$ & & & & G & G \\
\hline-0 II & & & $I$ & & & \\
\hline -ein & & & I & $G$ & G & G \\
\hline$-\ddot{e}{ }^{\prime}$ & & & $I$ & & & \\
\hline$-\mathrm{B}$ & NA & & NA & & G & $G$ \\
\hline$-O B$ & & & & $\mathrm{AG}$ & & \\
\hline$-e B$ & & & & $A G$ & & \\
\hline -ёB & & & & $\overline{A G}$ & & \\
\hline$-\mathrm{aM}$ & & & & $D$ & D & D \\
\hline$-9 M$ & & & & $\bar{D}$ & $\mathrm{D}$ & $\bar{D}$ \\
\hline$-O M$ & $I$ & I & & & & \\
\hline -eM & $I$ & $I$ & & & & \\
\hline - ËM & I & I & & & & \\
\hline$-2 M и$ & & & & I & I & $I$ \\
\hline -ЯМИ & & & & $I$ & I & $I$ \\
\hline$-a x$ & & & & $P$ & $P$ & $P$ \\
\hline$-9 X$ & & & & $P$ & P & $P$ \\
\hline
\end{tabular}

*No ending; the word ends in a consonant which remains an integral part of the word in all case variations. Examples are such masc. words(N-sg.) as CTOЛ, Порт, тоM, волі,

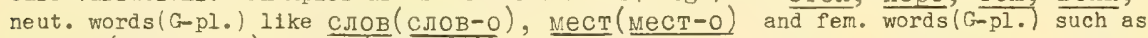
номнат ( помнат-а), книг (иниг-a).

* Parentheses indicate a usage by a restricted number of nouns. 
Index of Signals - Adjective Endings

\begin{tabular}{|c|c|c|c|c|}
\hline & \multicolumn{3}{|c|}{ Singular } & Plural \\
\hline-2, & Masc. & Neut. & $\frac{\text { Fem. }}{N}$ & $\underbrace{\text { Masc. }} \quad$ Neut. \\
\hline$-9 A$ & & & N & \\
\hline -БЯ & & & $\mathbb{N}$ & \\
\hline$-0 e$ & & NA & & \\
\hline$-e e$ & & NA & & \\
\hline$-\mathrm{se}$ & & NA & & \\
\hline - He & & & & NA \\
\hline -ne & & & & NA \\
\hline$-5 V$ & & & - & NA \\
\hline$-y \div 0$ & & & A & \\
\hline$-10 \%$ & & & A & \\
\hline$-\mathrm{BH}$ & & & A & \\
\hline-010 & & & I & \\
\hline$-e ю 1$ & & & I & \\
\hline -แй & NA & & & \\
\hline -ИЙ & NA & & & \\
\hline-0 ĭ & NA & & GDPI & \\
\hline$-e \ddot{1}$ & & & GDPI & \\
\hline -oro & $A G$ & G & & \\
\hline -ero & $A G$ & G & & \\
\hline$-O M$ & $P$ & $P$ & & \\
\hline$-e \mathrm{M}$ & P & $P$ & & \\
\hline$-\mathrm{BM}$ & $I$ & I & & D \\
\hline -IIM & I & I & & D \\
\hline -OMY & D & D & & \\
\hline -емy & D & D & & \\
\hline - - WMUI & & & & $I$ \\
\hline -иМи & & & & I \\
\hline$-\mathrm{HX}$ & & & & AGP \\
\hline$-\ln x$ & & & & AGP \\
\hline \multicolumn{5}{|c|}{ Short Forms } \\
\hline -(Zero) & $\mathrm{N}$ & & & \\
\hline$-a$ & & & $\mathbb{N}$ & \\
\hline-0 & & $\mathbb{N}$ & & \\
\hline-4 & & & & $\mathbb{N}$ \\
\hline
\end{tabular}




$$
\begin{aligned}
& \text {-нй/-ой/-иЙ } \\
& \text {-ое/-еe/-ье } \\
& \text {-ого/-его } \\
& \text {-ому/-ему } \\
& \text {-ом/-ем } \\
& \text {-нM/- МM }
\end{aligned}
$$

$$
\begin{aligned}
& \text {-ая/-яя/-ья } \\
& \text {-ую/-юю/-ью } \\
& -0 \text { Й/ } / \text { บทั } \\
& -0 \text { И/ } /-e \text { Й } \\
& -0 \grave{1} /-\in \bar{I} \\
& -010 /-010
\end{aligned}
$$

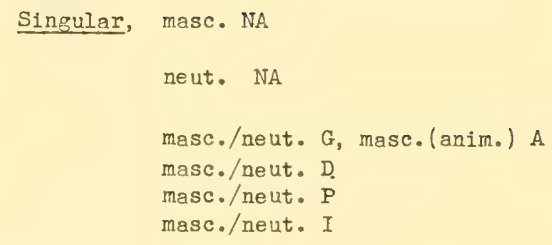

$$
\begin{aligned}
& -\mathrm{a} ศ /- \text { ร } / \text { - ธศ } \\
& - \text { Ую/-юю/-Бю } \\
& -0 \text { Й/ } / \text { - Й } \\
& -0 \vec{n} /-e \bar{n} \\
& -010 /- \text { ero }
\end{aligned}
$$

$$
\begin{aligned}
& \text { (Zero), - -й, - Б } \\
& -0 /-e /-\ddot{e} \\
& -a /-g \\
& -y / 10 \\
& -o M /-e M /-\ddot{e} M
\end{aligned}
$$

$$
\begin{aligned}
& -a /-9 \\
& -\mathrm{y} /-\mathrm{r} \\
& -\mathrm{H} /- \text { И } \\
& -e /- \text { и }
\end{aligned}
$$

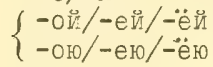

S1ngular,
fem. N
fem. A
fem. G
fem. DP
fem. I
fem. I

$$
\begin{aligned}
& \text { - нe/-ne/-ьи } \\
& \text { - מе/-me/-ьи } \\
& -\mathrm{HX} /- \text { IIX } \\
& -\mathrm{mx} /- \text {-иx } \\
& -\mathrm{HX} /-\mathrm{HX} \\
& -\mathrm{Hx} /-\mathrm{nX} \\
& -\mathrm{HX} /-\mathrm{nX} \\
& -\mathrm{EM} /-\mathrm{IIM} \\
& \text { - вмиі/-ими }
\end{aligned}
$$

$$
\begin{gathered}
-b \\
-b \\
-И \\
\left\{\begin{array}{l}
-b 10 \\
-510
\end{array}\right.
\end{gathered}
$$

$$
\begin{aligned}
& -\mathrm{H} /-\mathrm{II} \\
& -\mathrm{a} /-\Omega \\
& -O B /-e B \\
& \text { (Zero) } \\
& \text { - } \mathrm{B},- \text { Й } \\
& \text {-eй. } \\
& -a x /-g x \\
& -a M /-g M \\
& \text {-ами/-ями }
\end{aligned}
$$

fem. $N$

fem. A

fern. GDP

fem. I

fem. I

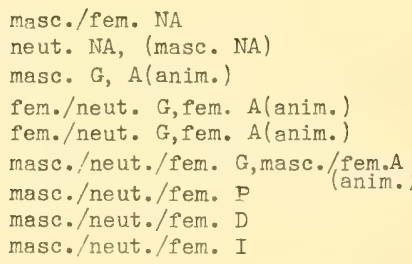




$\begin{array}{lc}-\mathrm{TB} & \text { Infinitive } \\ -\mathrm{TM} & " \\ -\mathrm{UB} & "\end{array}$

-TБCA

-тись

-ЧБC月

$-\pi$

$-\pi-a$

$-\pi-0$

- Л - И

$-\mathrm{y}$

$-10$

-еші

- е́யா

-ищь

-eT

-ёT

$-\mathrm{IT}$

$-e \mathrm{M}$

- ̈̈M

- IIM

-ete

-ёте

-ите

$-\mathrm{yT}$

$-10 T$

$-2 \mathrm{~T}$

-

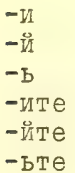

Past Tense, sing., masc., 1-2-3 persons

$$
\begin{array}{lcccc}
" ~ & n & & \text { fem. } & " \\
" & " & \text { neut., 3rd. person } \\
" & " & \text { pl., masc. fem.neut., } 1-2-3 \text { persons }
\end{array}
$$$$
\text { Present Tense, sing., 1st. person("I") }
$$$$
n
$$$$
\text { * }
$$$$
"
$$$$
\text { "1 }
$$$$
\text { n }
$$$$
\text { " }
$$$$
\text { " }
$$

Present Tense, pl., 1st. person("we")

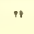$$
n
$$$$
\text { n }
$$$$
"
$$$$
\text { n n }
$$$$
\text { " }
$$$$
\text { 2nd. }
$$$$
\text { n }
$$$$
\text { " }
$$$$
3 \mathrm{rd} \text {. }
$$$$
\text { n }
$$$$
\text { " }
$$$$
\text { ("you") }
$$$$
\text { n }
$$$$
\text { " }
$$$$
\text { " }
$$$$
\text { , }
$$$$
\text { n }
$$$$
\text { " }
$$$$
+
$$$$
\text { ("they") }
$$$$
\text { "You[fam.]") }
$$$$
\text { n }
$$$$
\text { " ("he/she/it") }
$$$$
1
$$$$
\text { " " }
$$$$
\text { " } 4
$$

- JCR

-лась

- ЛОСb

-лись

$-\mathrm{yCb}$

- $10 \mathrm{Cb}$

-ешься

-ёшься

-ищвся

-ется

-ётся

-Ится

-емся

-ёмся

-

-етесь

-ётесь

-итесь

-Утся

-ются

-атся

- मTCम

$-\mathrm{YCb}$

- йс

-БСя

-итесь

一约теcb

-ьтесь 


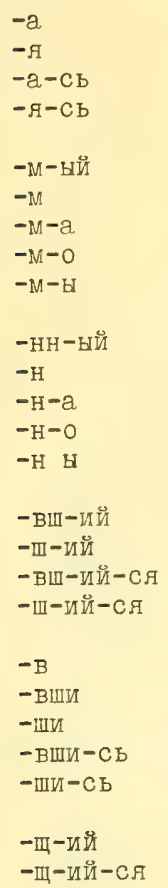

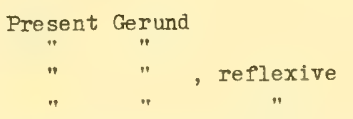

Present Passive Participle

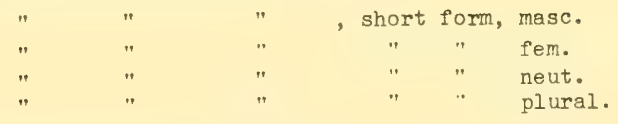

Past Passive Participle

\begin{tabular}{|c|c|c|c|c|c|c|}
\hline " & $n$ & $"$ & , & short & form, & masc. \\
\hline$"$ & $"$ & $"$ & & $*$ & " & fem. \\
\hline " & $"$ & $"$ & & $"$ & $"$ & neut, \\
\hline , & $"$ & $"$ & & $"$ & $"$ & plural \\
\hline
\end{tabular}

Past Active Participle

$\begin{array}{cccc}" & " & " & \\ " & n & n & \text {, reflexive }\end{array}$

\section{Past Gerund}

" "

" $"$

$" \quad$, reflexive

" "

Present Active Participle
$"$
"
, reflexive

" 


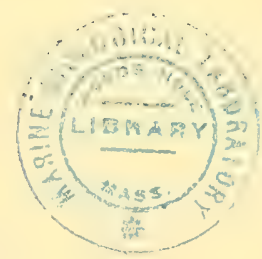

Phenomena, linguistic or other, of a high frequency of occurrence are quite obviously worthy of special note. This section presents, then, lists of Russian words and phrases which appear very frequently in Russian texts. The beginning student will spare himself much dictionary "thumbing" by an occasional review of this material. At the end of the section there are listed various general and special Russian dictionaries available in this country.

The contents of this section have been arranged in the following order:

1) Word Derivation

2) Prepositions

3) Connectives and Question Words

4) Frequently-used Present Tense Forms

5) Frequently-used Adverbs

6) Frequently-used Past Passive Participles

7) Frequently-used Phrases

8) List of Elements

9) Available Dictionaries

\section{1) Word Derivation}

Analysis of the constituents(prefix, root, suffix) of a new word in a foreign language is often helpful in determining the meaning of the word. It is a technique, however, which must be used with caution, since the meaning of the whole word may not necessarily be the sum of the constituent meanings, as a consideration of the English verb "understand" will demonstrate.

Prefixes and initial elements in common use, along with their meanings, are cited below. The student can determine the relevance of these "chunks" of meaning to his particular problem of learning vocabulary in the following manner: select one of the special dictionaries and leaf through it, observing whether or not these elements make their contribution to meaning in a consistent and predictable way.

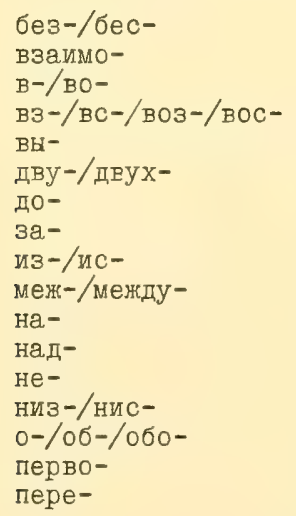

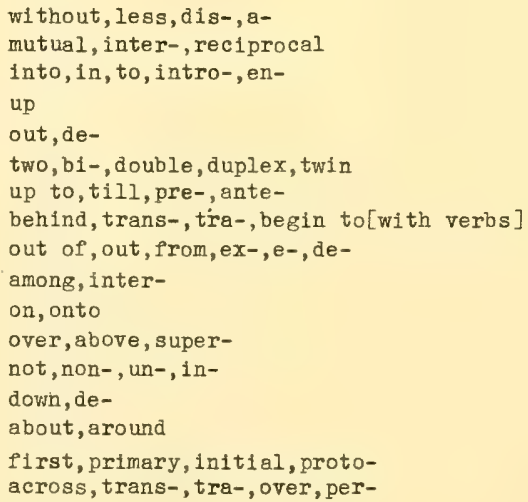



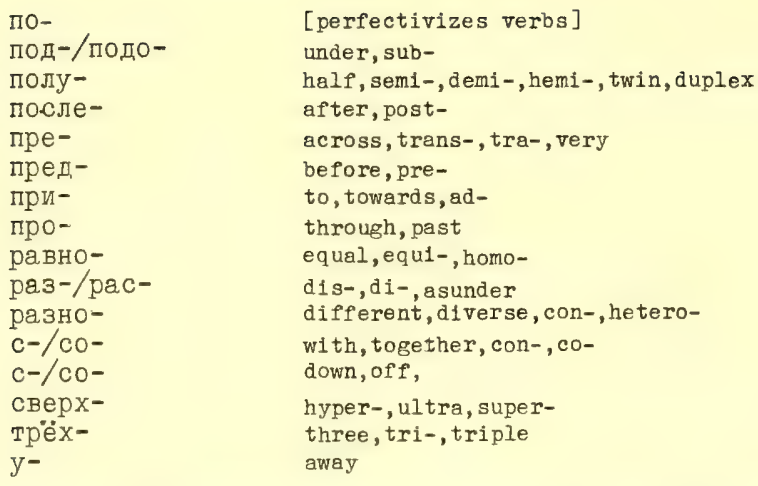

There are many suffixal elements used in the formation of nouns, adjectives and verbs, but the following selection contains the most important ones for the student.

\section{Adjectives}

\begin{tabular}{|c|c|c|c|c|}
\hline & дробь & "fraction" & пробнщй & "fractional" \\
\hline & институ́т & "1nstitute" & институ́тский & "institutional" \\
\hline -ий & оптина & "optics" & опти́ческий & "optical" \\
\hline
\end{tabular}

Nouns

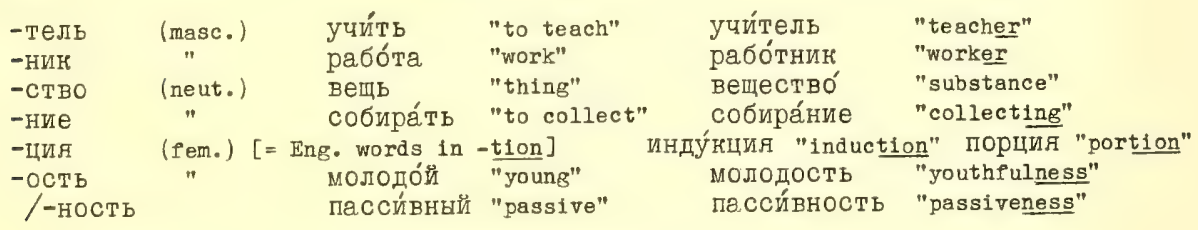

Verbs

$$
\begin{aligned}
& \text {-ова-ть } \\
& \text {-ирова-ть } \\
& \text {-изирова-ть }
\end{aligned}
$$

2) Prepositions

$\begin{array}{llll}\text { интере́с } & \text { "interest" } & \text { интересова́ть } & \text { "to interest" } \\ \text { нонтра́ст } & \text { "contrast" } & \text { нонтрасти́ровать "to contrast" } \\ \text { стабилиза́ция } & \text { "stabilization" стабилизи́ровать "to stabilize" }\end{array}$

$\begin{array}{lll}\text { без/безо, } & \text { (+G) } & \text { without } \\ \text { благодаря } & \text { (D) } & \text { thanks to, because of } \\ \text { близ/близо } & \text { (G) near } \\ \text { в/во } & \text { (A) } \text { into, on[temporal] } \\ \text { в/во } & \text { (P) } \text { in, at } \\ \text { вместо } & \text { (G) } & \text { in place of, instead of } \\ \text { Для } & \text { (G) } \text { for } \\ \text { до } & \text { (G) up to, as far as, t1ll } \\ \text { за } & \text { (A) behind, for } \\ \text { за } & \text { (I) behind, for } \\ \text { из/изо } & \text { (G) out of, from }\end{array}$




\begin{tabular}{|c|c|c|}
\hline $\mathrm{K} / \mathrm{KO}$ & (D) & to, toward, for \\
\hline нроме & (G) & besides, except \\
\hline между & (I) & between, among \\
\hline на & (A) & onto, into, for \\
\hline на. & (P) & on, in, at \\
\hline над/надо & (I) & over, on \\
\hline $0 / 06 / 060$ & (A) & ggainst \\
\hline $0 / 06 / 060$ & (P) & about, concerning \\
\hline оноло & (G) & around, about, approximately \\
\hline оT/OTO & (G) & from \\
\hline перед/передо & (I) & before, in front of \\
\hline по & (A) & up to, as far as \\
\hline по & (D) & through, according to, in \\
\hline по & (P) & after \\
\hline под/подо & (A) & under, near \\
\hline поп/попо & (I) & under \\
\hline после & (G) & after \\
\hline при & (P) & at, during, in presence of \\
\hline про & (A) & about, concerning \\
\hline против & (G) & opposite, against \\
\hline путём & (G) & by way of, by means of \\
\hline $\mathrm{c} / \mathrm{co}$ & (A) & about, approximately \\
\hline $\mathrm{c} / \mathrm{co}$ & (G) & from, off of, since \\
\hline $\mathrm{c} / \mathrm{co}$ & (I) & with, along with \\
\hline $\mathrm{y}$ & (G) & $\begin{array}{l}\text { near, at, at home of, in } \\
\text { possession of, from }\end{array}$ \\
\hline через & (A) & over, across, in [temporal] \\
\hline
\end{tabular}

\section{3) Connectives and Question Words}

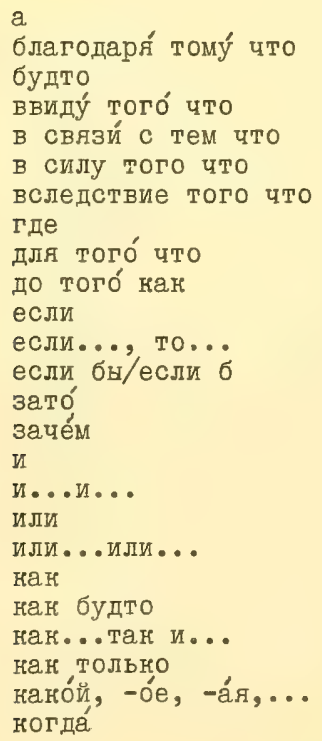




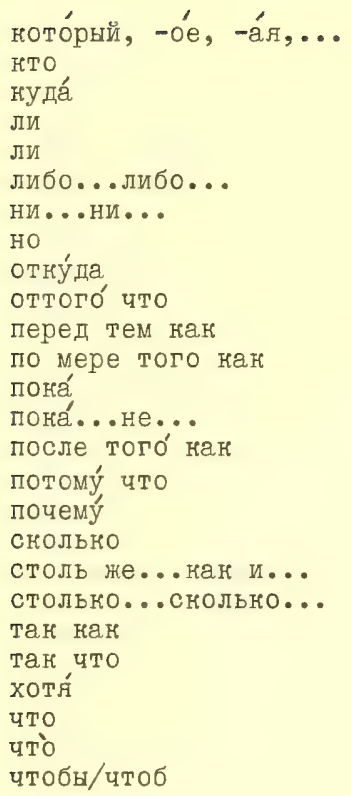

which, what

who

where, where to

? [indicates a question]

whether [in indirect question]

either...or...

neither...nor...

but

from where, whence

because

before

to the extent that, in proportion as, as

while, when

until

after

because

why

how much, how many

as...as...

as much/many.... as

because, since

such that

al though

what, that

that which

in order to, that

\section{4) Frequently-used Present Tense Forms}

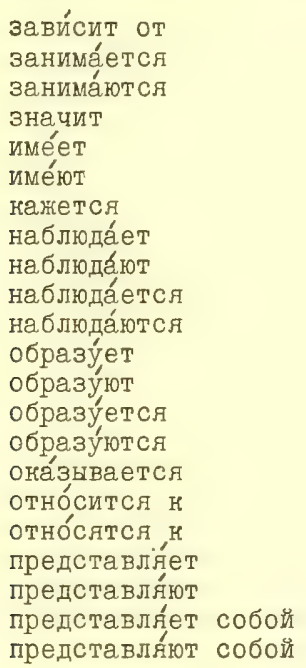

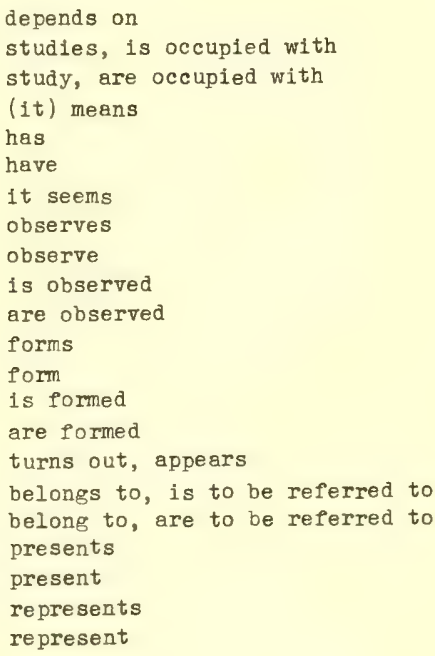

\footnotetext{
*In addition to the 3rd. sg. forms, the 3ra. pl. forms are cited, if they are used frequently.
} 


пременя́ет
пременя́ют
пременя́ется
пременйются
следует
составля́ет
составлятют
состойт из
состоя́т из
состойт в том что
состоя́т в том что
счита́ет
сиита́ют
счита́ется
счита́ются
удаётсл
явля́ется
явля́ются

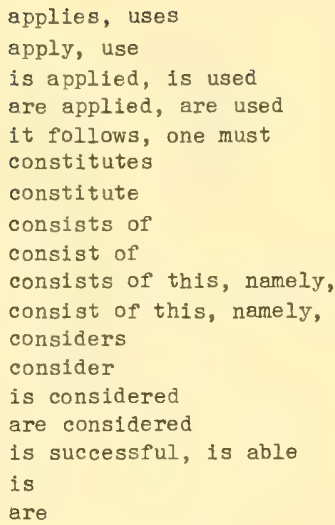

\section{5) Frequently-used Adverbs}

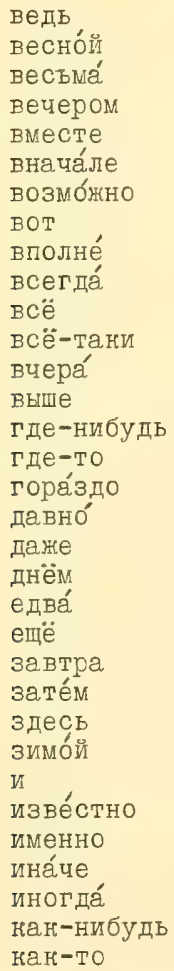

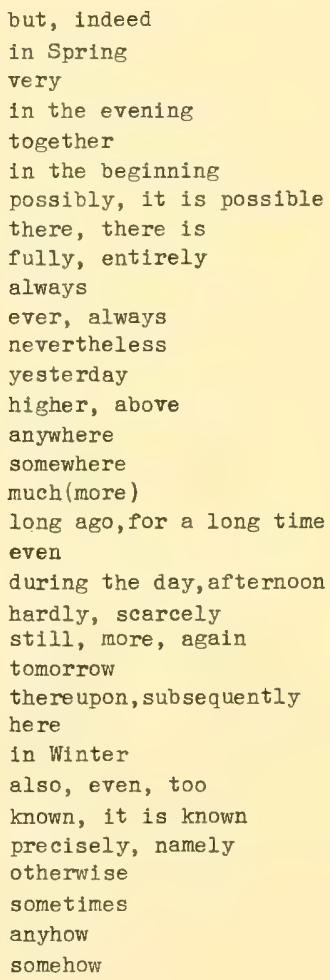




\begin{tabular}{|c|c|}
\hline когда́-нибудь & anytime \\
\hline когпа́-то & sometime \\
\hline Нонечно & of course \\
\hline летом & in Summer \\
\hline лишь & hardly, only \\
\hline МОЖHO & possible, it is possible \\
\hline напо & necessary, it is necessary \\
\hline наза́д & back, backwards \\
\hline наноне́ц & finally \\
\hline нале́во & on the left, to the left \\
\hline напра́во & on the right, to the right \\
\hline $\mathrm{He}$, & not \\
\hline нельзя & it is impossible \\
\hline Немно́го, & not much, a little \\
\hline необходимо & (it is) necessary \\
\hline ниже , & lower, below \\
\hline ниногда́ & never \\
\hline НОЧЬю & at night \\
\hline одна́ко & however \\
\hline ОПЯт В & again \\
\hline Осенью & in Autumn \\
\hline осббенно & especially \\
\hline Очень & very \\
\hline ПОТО'M & $\begin{array}{l}\text { afterwards, then } \\
\text { almost }\end{array}$ \\
\hline ПочтИ & seldom, rarely \\
\hline редно & $\begin{array}{l}\text { seldom, rarely } \\
\text { alongside }\end{array}$ \\
\hline рядОМ & $\begin{array}{l}\text { alongside } \\
\text { today }\end{array}$ \\
\hline сегод̆Н & \\
\hline сейча́c & $\begin{array}{l}\text { now, this moment } \\
\text { from the left }\end{array}$ \\
\hline слева & \\
\hline слишном & too, too much \\
\hline снача́ла. & at first, to begin \\
\hline совсе́M & wholly, completely \\
\hline справа & from the right \\
\hline сразу & at once \\
\hline СТОЛЬКО & so many \\
\hline сюда́ & here, to here \\
\hline TaH & thus, so \\
\hline танже & also, Iikewise \\
\hline TaM & there \\
\hline теперь & now \\
\hline тоже & $\begin{array}{l}\text { also } \\
\text { only }\end{array}$ \\
\hline $\begin{array}{l}\text { тольно } \\
\text { тупа́ }\end{array}$ & there, to there \\
\hline тут & $\begin{array}{l}\text { here } \\
\text { here, to here }\end{array}$ \\
\hline уже & already \\
\hline утром & in the morning \\
\hline хорошо & well, (it is) good \\
\hline часто & often \\
\hline чем & than \\
\hline
\end{tabular}


6) Frequently-used Past Passive Participles

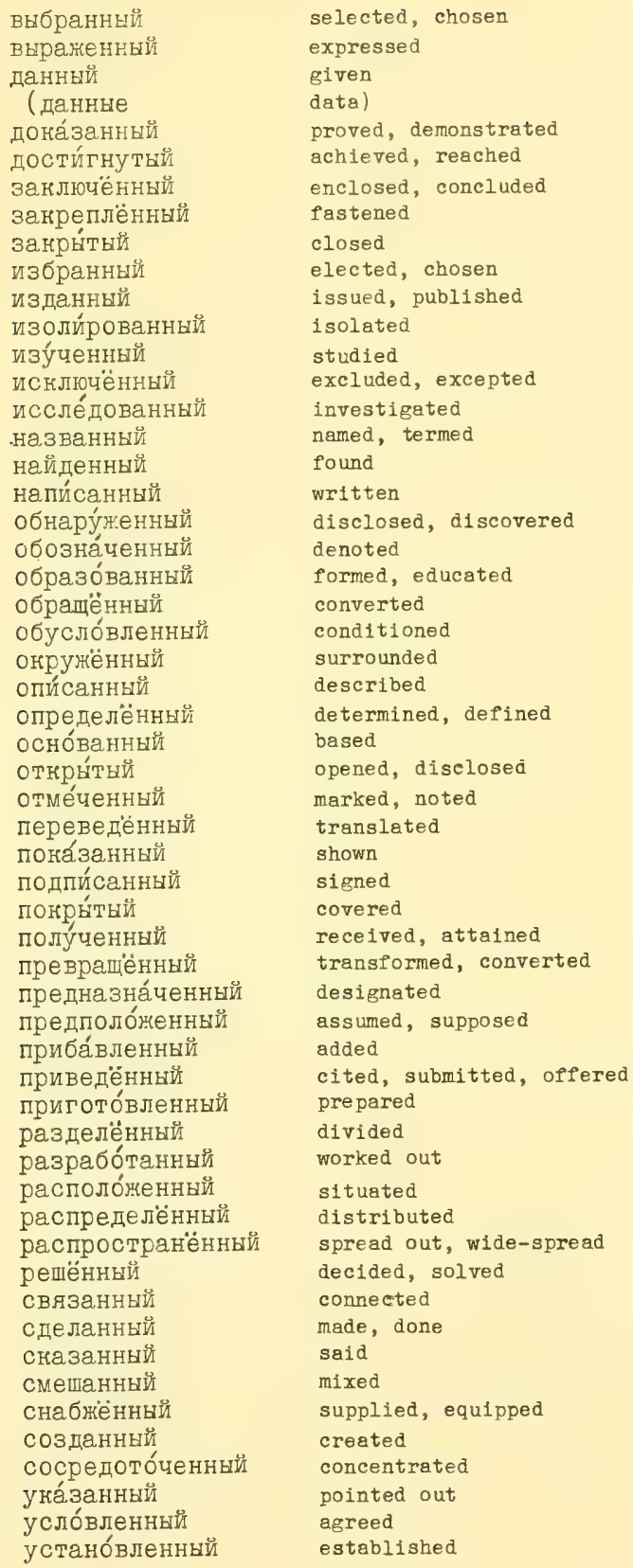


7) Frequently-used Phrases

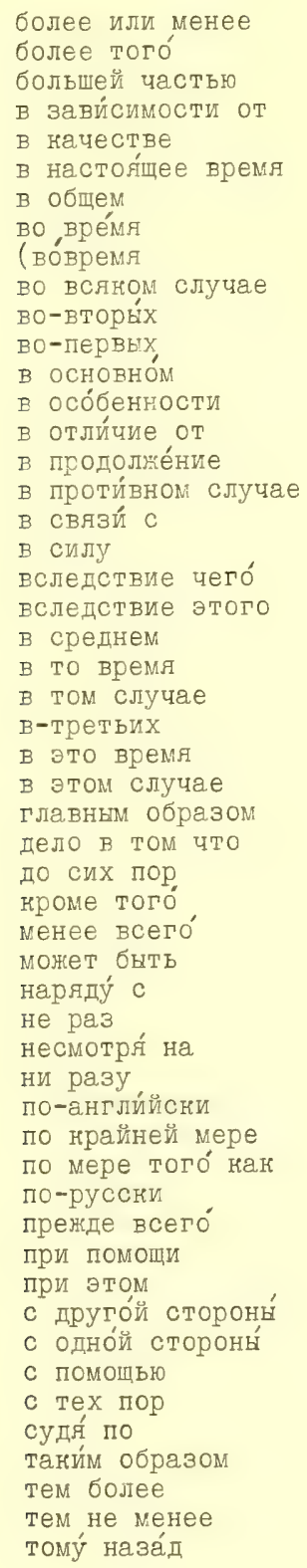

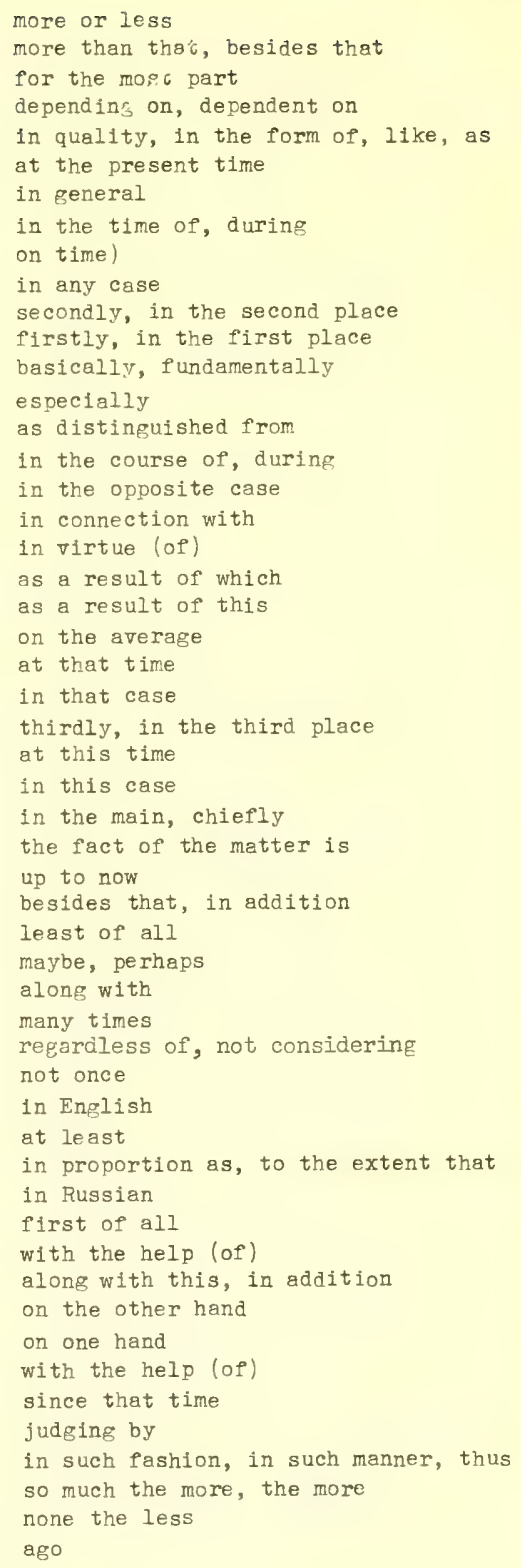




\section{8) List of Elements}

Though this manual does not attempt to compete with the dictionary in providing meaning equivalents, still it seems desirable to aid the student in the matter of Russian terminology for the basic elements, since these terms are not readily accessible. The Russian terms have been alphabetized and are followed, in each case, by the English term, the symbol and the atomic number. Russian uses Latin letters for the symbols, which are the same for both languages with but one exception(see тулий).

\begin{tabular}{|c|c|c|c|}
\hline азо́т & nitrogen & непту́ний & neptuni um \\
\hline ฉ.тииний & actinium & никель & nickel N1 28 \\
\hline алюми́ний & aluminum Al 13 & нио́бй & niobium $\mathrm{Nb} 41$ \\
\hline амери́ций & americum Am & нобелий & nobelium ? 102 \\
\hline apróH & argon A 18 & ОЛОВО & tin $\mathrm{Sn} 50$ \\
\hline а.статин & astatine At 85 & осмий & osmium os 76 \\
\hline барий & barium $\mathrm{Ba} \quad 56$ & па.лла́дий & palladium Pd 46 \\
\hline $\begin{array}{l}\text { бериллий } \\
\text { бернелий }\end{array}$ & $\begin{array}{lll}\text { beryllium } & \mathrm{Be} & 4 \\
\text { berkelium } & \mathrm{Bk} & 97\end{array}$ & $\begin{array}{l}\text { платина } \\
\text { плуто́нуй }\end{array}$ & $\begin{array}{lll}\text { platinum } & \text { Pt } & 78 \\
\text { plutonium } & \text { Pu } & 94\end{array}$ \\
\hline $60 \mathrm{p}$ & boron B 5 & поло́ниџ̆ & polonium Po 84 \\
\hline бром & bromine Br 35 & празеопйм & praseodymium Pr 59 \\
\hline вана́,пий & vanadium $V 23$ & проме́тиі & promethium Pm 61 \\
\hline BИ СMYT, & bismuth B1 83 & протакти́ний & protactinium $\mathrm{Pa} \quad 91$ \\
\hline водоро́д & hydrogen $\mathrm{H} \quad 1$ & радий & radium $R a \quad 88$ \\
\hline вольфра́м & tungsten/wolfram W & рапо́н (/әман & Ә́ция) radon $\mathrm{Rn}$ \\
\hline гаполиний & gadolinium Gd 64 & рений & rhenium $\operatorname{Re}$ \\
\hline га.ллиї & gallium Ga 31 & родий & rhodium Rh 45 \\
\hline га.бний & hafnium Hf 72 & ртуть & mercury $\mathrm{Hg} 80$ \\
\hline гелий & hellum $\mathrm{He} 2$ & рубйпий & rubidium $\quad R b \quad 37$ \\
\hline герма́ниї & germanium fe 32 & руте́ний & ruthenfum Ru 44 \\
\hline ГОЛЬМуї & holmium Ho 67 & самв́рий & samarium Sm 62 \\
\hline диспро́зий & dysprosium Dy 66 & свинёц & lead $\mathrm{Pb} 82$ \\
\hline евро́пий & europium $\mathrm{Eu} \quad 63$ & селе́н & selenium Se 34 \\
\hline неле́зо & iron $\mathrm{Fe} 26$ & cepa & sulfur $\mathrm{S} \quad 16$ \\
\hline ЗОЛОТО & gold Au 79 & cepeбpó & silver Ag 47 \\
\hline индий & indium In 49 & скандй & scandium Sc 21 \\
\hline ИÓI & iodine I 53 & стронций & strontium Sr 38 \\
\hline ири́дий & iridium Ir 77 & сурьма́ & antimony $\mathrm{Sb} \quad 51$ \\
\hline итте́рбий & ytterbium Yo 70 & таллий & thallium T1 81 \\
\hline иттрий & yttrium $Y 39$ & танта́л & tantalum Ta 73 \\
\hline на.дмичі & cadmium Cd 48 & теллур & tellurium Te 52 \\
\hline калй̆ & potassium $\mathrm{K} \quad 19$ & тербиі & terbium Tb 65 \\
\hline на.лиђо́рний & californium Cf 98 & техне́ций & technetium Tc 43 \\
\hline нальций & calcium Ca 20 & тита́н & titanium $\mathrm{T} 1 \quad 22$ \\
\hline пислоро́д & oxygen 08 & торий & thorium Th 90 \\
\hline нобальт & cobalt Co 27 & тулий , & thulium Tm, Tu[Russian] \\
\hline „ремНй & silicon Si 14 & углероп & carbon C 6 \\
\hline нрипто́н & krypton Kr 36 & ура́.н & uranium U 92 \\
\hline FCeHÓH & xenon $\mathrm{Xe} \quad 54$ & фермий & fermium Fm 100 \\
\hline нюриЙ & curium $\quad \mathrm{Cm} \quad 96$ & doc d్రంp & phosphorous $P 15$ \\
\hline गа.Нте́.H & lanthanum La 57 & ஸранций & francium Fr 87 \\
\hline Јитий & Iithium Li 3 & m̃TOp & fluorine $F \quad 9$ \\
\hline люте́ций & lutetium Lu 71 & xлIOp & chlorine Cl 17 \\
\hline магний & magnesium $\mathrm{Mg} \quad 12$ & $\mathrm{XPOM}$ & chromium Cr 24 \\
\hline марганец & manganese Mn 25 & це & cesium Cs 55 \\
\hline мепв & copper $\mathrm{Cu} 29$ & церий & cerium $\mathrm{Ce} 58$ \\
\hline менделе́виї & mendelevium IV 101 & ЦИНК , & zinc $\mathrm{Zn} 30$ \\
\hline $\begin{array}{l}\text { молибде́н } \\
\text { мышья̆н }\end{array}$ & $\begin{array}{l}\text { molybdenum Mo } 42 \\
\text { arsenic As } 33\end{array}$ & $\begin{array}{l}\text { цирноний } \\
\text { эйнште́йнй }\end{array}$ & $\begin{array}{lll}\text { zirconium } & \text { Zr } & 40 \\
\text { einsteinium } & \text { E } & 99\end{array}$ \\
\hline натриц & sodium $\mathrm{Na} 11$ & әмана́ция $(/ \mathrm{p}$ & До́н) emanation Em \\
\hline неодїм & neodymium Nd 60 & өрбий & erbium $\operatorname{Er} 68$ \\
\hline & neon $\mathrm{Ne} 10$ & & \\
\hline
\end{tabular}




\section{9) Available Dictionaries}

It can be said that the scientist will require at least two dictionaries for the translation of Russian texts. One dictionary will be general in nature, that is, the usual Russian-English type; the other will contain terms specific to technology or to a particular scientific field. Since dictionaries of the latter type are usually expensive, the student is advised to check the resources of the nearest library for works in this area.

Dictionaries are listed below in two categories: General, and Scientific. The number of entries in General category could easily be increased, but the ones cited are those in common use in this country. The listing of dictionaries in the Scientific category is(to the writer's knowledge) complete, though new glossaries are undoubtedly now in preparation. Data concerning publication, number of pages, etc., are given, where known; the prices listed have been taken from various book lists, but they may well have been changed by now.

\section{General}

1) M. A. O'Brien, New English-Russian and Russian-English Dict., 767 pp., Dover Publ.,

2) L. Segal, Russign-English Dict., 4th. ed., 1,016 pp., Stechert Co., New York, 1951. \$10.00. [has many scientific terms]

3) A. I. Smirnitsky, Russian-English Dict., 3rd. ed., 951 pp., Moscow, 1958. $\$ 4.50$. [an excellent dict. with many scientific terms]

Scientific

Biology: 1) Russian-English Hydrobiology Glossary, 85 pp., 6, 000 terms, Consultants Bureau, New York, 1958. \$1.20.

2) Cr. Medicine, No. I.

Chemistry: 1) L.I.Callaham, Russian-English Technical and Chemical Dict., 794 pp., Wiley and Sons, New York, 1956. \$16.50.

Commerce: 1) B. T. Kolpakov, Russian-English Glossary of Economic and Trade Terms, 800 terms, Telberg Book Co., New York, 1958. \$3.50.

Electronics: 1) English-Russian, Russian-English Electronics Dict. (TM 30-545, Army

2) P. Robeson(ed.), Russian-English Glossary of Electronics and Physics, 343 pp., Consultants Bureau, New York,195\%. \$10.00.

3) Lists of Russian electronic terms with English equivalents in Proceedings of the IRE, 1ssues: June 1954; Jan., May, Aug., Nov. of 1956.

4) Russian-English - English-Russian Electronics Dict. , McGraw-Hill, London, 1958.

5) L. K. Ptashny, English-Russian Dict. on Automation and Control Instruments, Moscow, 1957. \$1.50. [this may be used as a Russian-English dict.; since pages 259-279 offer an index of all Russian terms with references to the English entries]

Geography: 1) T. Deriugina, Dict. of Russian Geographical Names, 4, 500 names, Telberg Book Co., New York, 1958. \$9.80.

2) Soviet Topographic Map Symbols (TM 30-548), U.S. Gov't Printing Office, Washington, D.C., 1958. \$1.00.

Mathematics: 1) Russian-English Vocabulary, $66 \mathrm{pp}$. in all, $39 \mathrm{pp}$. of terms, Amer. Math. Soc., Rhode Island, 1955. \$1.20.

Medicine: 1) E. A. Carpovich, Russian-English Biological and Medical Dict., 400 pp., 35,000 terms, Technical Dict. Co., New York, 1958.

2) S. Jablonski, Russian-English Medical Dict., 423 pp., Academic Press, New York, $19 \overline{58 . \$ 11.00 . ~}$ 


\section{Dictionaries(continued)}

Meteorology: 1) W.A. Baum, Russian-English Dict. of Meteorological Texms and Expressions, $175 \mathrm{pp}$., Washington, 1949. \$7.50.

2) Russian-English Dict. of Meteorological and Related Terms, Gov't Printing Office, Washington, 1943.

Mining: 1) A. Akhonin, Russian-English Glossary of Metallurgical and MetalWorking Terms, 175 pp., Center for Int'l Studies(MIT), Cambridge, 1955.

Physics: $\quad$ 1) E.A. Carpovich, Russian-English Atomic Dict., 317 pp.,23,000 terms, Technical Dict. Co., 1957. \$12.00.

2) I. Emin(ed.), Russian-English Glossary of Solid State Physics, 90pp., 4,000 terms, Consultants Bureau, New York,1958. \$10.00.

3) Glossary of Technical Terms: English, Chinese, French, Russian, Spanish (United Nations, Atomic Energy), 182 pp., 1953. \$3.00.

4) D. I. Voskoboinik(ed.), Russian-English Dict. of Nuclear Physics and Engineering, 350 pp., Moscow,1955. Reprint,Assoc.Tech.Serv., Orange, N.J., 1956. \$9.00.

5) Cf. Electronics, No. 2.

Rockotry: 1) A. M. Mursshkevich, English-Russian Rocket Dictionary, Moscow, 1958. \$1.50. (This may be used as a Russian to English dictionary, since pages 170 to 231 contain an alphabetical listing of the Russian terms with page references to English entries.)

Technical: 1) A. Bray, Russian-English Scientific Technical Dict., 551 pp., New York, $1945 . \$ 10.00$.

2) I.N. Kondratov, Russian-English Polytechnical Dict., Moscow, 1946 ; London, 1948.

3) Cf. Chemistry, No. 1.

Other Lexical Aids:

1) A. Rosenìerg, Russian Abbreviations: A Selected List, 2nd. ed., 513 pp., Library of Congress(Gor't Printing Office), 1957. \$2.75

2) Лехин и Петров, Словарь иностранных слов (Dictionary of Foreign Words), 5th. ed., 20,000 words, Moscow, 1955. [though all in

Russian, this dict. is valuable because it identifies many scientific terms recently borrowed into Russian]

3) Kратний политехнический словарь (A Short Polytechnical D1ct.), 1,136 pp., Moscow, 1956. \$7.00. [though all in Russian, this dict. is profusely illustrated with drawings and sketches] 


\section{SECTION V}

\section{TECHNIQUES OF TRANSLATION}

\section{Preparation of Aids}

The chief aids to translation will be the dictionary or dictionaries and this manual. Both the student's personal dictionary and the manual should be tabbed(equipped with projecting indices) for ready reference.

Translation

Out of an experience of observing many American scientists enter upon the task of Russian translation the following procedure for approaching a Russian sentence has been developed by the author.

1) Is a tense form(present, past, future) of the verb expressed?

2) If no tense form of the verb appears, the "is $\overline{\text { are" }}$ can be indicated by:
a) an adverb, e.g MO世HO "it is possible (to)"

b) a question word, e.g. KTO - OH? "Who is he?"

c) это "it is, that is, they are"

d) ВОт "there is, there are"

e) the equation of two nouns, e.g.

Виология - науна. "Biology is a science"

f) the equation of noun and adjective, e.g. Стоимость - высона. "The cost is high"."

3) If there is a verb, is it:

a) singular or plural?

b) 1 st., 2 nd. or $3 \mathrm{rd}$. person? (The $3 \mathrm{rd}$. person is the one in predominant use in scientific texts.)

c) present, future or past tense? (Remember that perfective verbs have future meaning in "present" forms.)

4) If a verb is expressed in the singular, for example, look for a possible singular subject, that is, a singular noun, adjective or pronoun in the nominative case.

5) With the verb and subject determined, look for a possible object in the accusative case.

6) When a preposition occurs, determine the noun which terminates the prepositional phrase. If a phrase is complicated, isolate the core: preposition and terminal noun, then work back from the noun, adjective by adjective, towards the prep.

7) In constructions which students refer to as the "on-the-corner-standing-man" type, that is, where one or more phrases are enclosed withing a phrase, translate the basic phrase first, then the enclosed phrase or phrases. Often a "who" or "which" clause will be needed for rendering an unwieldy phrase into acceptable English.

\section{Some Examples}

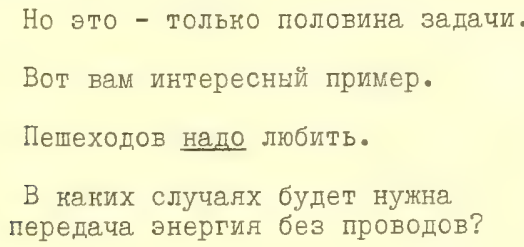

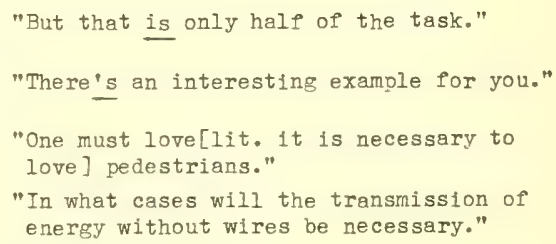


A 1. Большое место в творчестве Ломоносова занимали вопросы оптики. " large place in creative work of Lomonosov occupied questions of optics"

2. занимали - verb, plural, past tense

3. вопрос트 - noun, plural, $\mathrm{N}$ or $\mathrm{A}$, here $\mathrm{N}$ as subject

4. вопросы занимали место - the nucleus of the sentence

5. вопросн оптики занимали большое место.

6. в твориестве

7. ЛомОНОСОва.

8. в творчестве Јомоносова

9. Вопросн оптики занимали большое место в творчестве Ломоносова. "Questions of optics occupied a large place in the creative work of Lomonosov."

В 1. Ссобенно велики амплитуды температур воздуха в пустынях тропичесних областей.

"Especially high amplitudes of temperatures of air in deserts of tropical

2. амплитуды - велики "the amplitudes are high" - the nucleus of the sentence

3. амплитуды температур

4. амплитуды температур воздуха

5. в пустннях

6. в пустннях тропичесиих областей

7. Амплитуды температур воздуха в пустынях тропичесних областей

- особенно велини.

"The amplitudes of air temperature(s) are especially high in the deserts of tropical regions."

C 1. США ...привлекли имевших опыт немециих специалистов.. "USA ...attracted having had experience German specialists..."

2. CILA привленли специалистов. "The USA attracted specialists." - the nucleus

3. США привленли немециих специалистов

4. США привленли немециих специалистов, имевших опнт.

"The USA ... attracted German specialists, who had experience.

D 1. Известннй в-Англии нонстругтор управляемнх снарядов и ракет "well-known in England designer of guided missiles and rockets

К. Гэтланд во введении г своей переизданной в 1956 г. и переведенной

C. Gatland in introduction to his reprinted in 1956 year and translated

на русекий язнк книге... пишет...

into Russian language book...writes...

2. нонструнтор управляемнх снарядов и ранет, К. Гэтланд, известний в Англии... пишет...

3. во введении 4. н книге 5. к своей нниге

6. к своей книге, переизданной в 1956 году и перєведенной на русский язык.

7. Во введении н своей нниге, переизданной в 1956 году и переведенно: на руссний язын, К. Гәтланд, конструктор управляемых снарядов и ракет, известний в Англии, пишет...

"In the introduction to his book, which was reprinted in 1956 and (then) translated into Russian, C. Gatland, a designer of guided missiles and rockets, wellknown in England, writes... 


\section{SECTION VI}

\section{RUSSIAN TEXTS AND GLOSSARY}

Coming to a collection of Russian texts, the scientist will undoubtedly search eagerly for an article in his particular field. It is, obviously, impossible to present a completely representative body of texts and, furthermore, it is not necessary. At this stage the student must learn above all to manipulate the Russian grammatical apparatus and this can be done effectively with any non-literary Russian texts. With one exception(3) the texts included in this manual are all concerned with scientific subjects, so selected as to provide interesting, as well as useful, reading.*

\section{Texts}

1 Theory

2 Peter L. Kapitsa (an outstanding Russian physicist)

3 Dostoevsky and Sputnik

4 Classification of Insects

5 Suitable Units of Measurement

6 A toms

7 The Syndrome of Dementia

8 Chemical Abstracts

9 Differential Equations

10 The Use of Radioactive Isotopes in Medicine

\footnotetext{
* If the student feels the need of guidance in reading these texts and if there is no course in Scientific Russian at a local educational institution, he may wish to take advantage of the course in Scientific Russian recently announced by the Correspondence Study Department of the University of Minnesote. The correspondence course will cover these texts and others, to be selected by the individual students.
} 


\section{1 ТЕОРИЯ}

ТЕОРИЯ (от греческого слова эєшрí - рассмотрение, исследование, научное познание) - система основных идей в той или иной отрасли знания, обобщающих опнт, прантину и отражаюих объективные занономерности приропы, общества и человеческого мыпления. Применение термина весьма многообразно, однако областью, пде он правомерен в прямом и точном своём смысле, является только наука.

Научная теория опирается на результаты наблюдений, энспериментов, прантики, т. е. имеет объективное обоснование. Но простое описание фактов, перечисление того, что известно о них из әмпиричесиих наблюдении, ещё не составляет теории. В сравнении с данными опыта теория представляет собой новое, более глубоное, обобщённое знание, выранаюее результатн антивного пронинновения человена в объентивную действительность с помощью абстрантного мышления.

\section{Опираюееся на прантину обобщённое знание выранается в науне} не только в форме теории, но и в форме гипотезн и научного занона.

\section{(Большая Советскал Энциклопедия, том 42, стр. 228)}

\section{2 КАПИЦА}

КАПИЦА, Пётр Леонидович (родился 1894) - советсний бйин, анадемик(с 1939), Герой Социалистичесного Труда(1945). В 1918 окончил Политехнический институт в Петрограде. Первые работы Капицы посвящены изучению инерции әлегтронов и изучению свойств радиоантивного излучения. Капица разработал установку для работ со сверхмощными магнитными полями. Он наблюдал расщепление спентральных линий в полях до 320 килогаусс, обнаружил в сильных магнитных -полях линейное увеличение әлентрического сопротивления металлов в зависимости от поля и изучал магнитострикцио диамегнитных тел в этих полях. 
Капица разработал водородный оминатель большой производительности, сконструлровал и осутествил оригинальную установну для ожижения больших количеств гелия апиабатичесним методом. С 1935 до 1946 Капица был дирежтором Института физических проблем Анадемии наук СССР. Капица разработал новый метод ожижения воздуха с помоцью цинла низного давления и применения турбодетандера (см. Детандер). Используя турбодетандерның метод ожижения воздуха, Капица создал мощную установюу для получения больших ноличеств жидного кислорода путём ректиринации.

За работу "Турбодетандер для получения низких температур и его применения для ожижения воздуха"(1939) Капица в 1941 удостоен Сталинсной премии. Им проведены исследования свойств жидного гелия II (см. Гелий) и отнрыто явление сверхтенучести (см.). За эти работы, результаты ноторых опублинованы в трудах "Теплоперенос и сверхтенучесть гелия II"(1941) и "Исследование механизма теплопередачи в гелии II"(1941), Капица в 1943 удостоен Сталинской премии. В связи с изучением действия ректио̆инационных нолонн Капицей проведены исследования волновых и тепловых процессов в двунущихся тонких слоях жидности. Награждён тремя орденами Ленина и двумя медалями .

\section{(Большая Советская Әнцинлопедия, Т. 20, стр. 74)}

\section{3 СТУТнИК}

- Что станетсл в пространстве с топором? Quelle idee! Если куда попадёт подальше, то примется, я думаю, летать вокруг земли, сам не зная зачем, в виде спутнина. Астрономы вычислят восхождение и захондение топора, Гатцук внесёт его в налендарь, вот и всё.

(Ф. M. Постоевский, Братья Карамазовы, часть 4, глава 1Х) 


\section{4 СИСТЕМАТИКА НАСЕКОМИХ}

В настоящее время описано оноло 750 тысяч видов насеномых. В действительности же их число, повшдимому, значительно больше. Класс насеномых делится на два поднласса: низших - бескрылых насекомых (Apterygota), и вьсших - нрылатых насеномнх (Pterygota). Первый поднласс объединяет 4 отряда: бессяжновых, ногохвостных, вилохвостных и петинохвостных. Второ подкласс делится на два отдела: древненрылых (Palseopters), внлючащих 2 отряда - подёнии и стренозы, и новокрылых(Neoptera). Последние разделяются на 3 подотдела: Polyneoptera, нуда входят тарананы, богомолы, термиты, пряможрылье, палочниновые, веснянни, эмбии и уховертни; Paraneoptera,внлючающие отряды полужестнокрылых, равнонрылых хоботных, сеноедов, пухоедов, вшей, трипсов, и oligoneopters, пуда входят жуки, вислонрылки, верблюдки, сетчатонрылые, скорпионницы, двунрнлые, блохи, перепончатонрнлье, ручейники и чепуенрылые.

\section{(Большая Советсная Бнцинлопедия, т. 29, стр. 191)}

\section{5 УДОВНЦЕ ЕДИНИЦШ ИЗМЕРЕНИЯ}

Размерн атомов и моленул очень малы, во много раз меньше овружающих нас предметов. Чтобы измерять эти частицн, необходимо выбрать подходящие единицы измерения.

Определяя размеры вещей, мы пользуемся в жтейской прантике метрами и сантиметрами. Самне маленьние предметы, ноторые мы еще видим глазом, удобнее измерять миллиметрами. Миллиметр - это десятая доля сантиметра.

Единицей, удобной для измерения частичек, видимых в микроскоп, является микрон. Один микрон в тысячу раз меньше миллиметра.

$$
1 \text { микрон }=\frac{1}{1000} \text { миллиметра }
$$

Для измерения же атомов и молекул применяется единица, которая еще в тысячу раз меньше минрона. Ее называют миллиминроном.

$$
1 \text { миллимикрон }=\frac{1}{1000} \text { минрона }=\frac{1}{1000000} \text { миллиметра }
$$

Часто тағже пользуются единицей, еде в десять раз меньшей; она называется ангстрем.

$$
1 \text { ангстрем }=\frac{1}{10} \text { миллиминрона }
$$

Невооруженным глазом можно видеть предметы размером до нескольких деслтых долей миллиметра, то есть до нескольких сотен минронов. При помощи хорошего микроснопа можно разглядеть предметы, имеюие размеры до одного микрона. Недавно изобретенные электронные микроснопы позволяют отодвинуть границу невидимого до неснольких миллимикронов. Меньших частиц мы увидеть пона не можем и судим об их размерах тольно по носвенным признанам (нан можно измерить величину частиц, не видя их, вы узнаете далее в этой ннижне).

А теперь, выбрав единицы измерения для атомов ил молекул, познаномимся с устройством этих невидимых частичек.

(А. И. Китайгородский, Строение вещества и его әнергия, стр. 7-8) 
불.

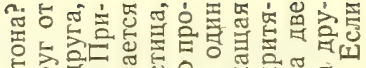

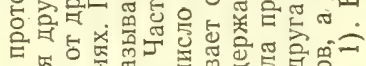

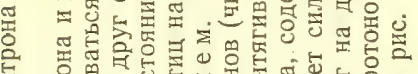

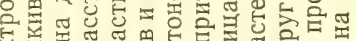

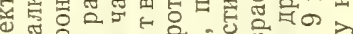

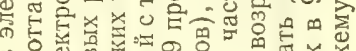

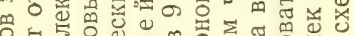

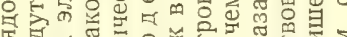

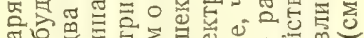

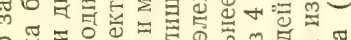

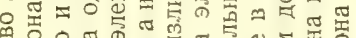

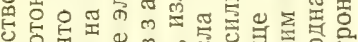
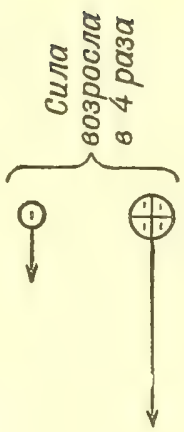

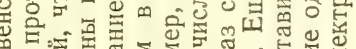

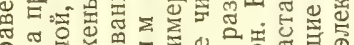

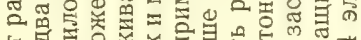
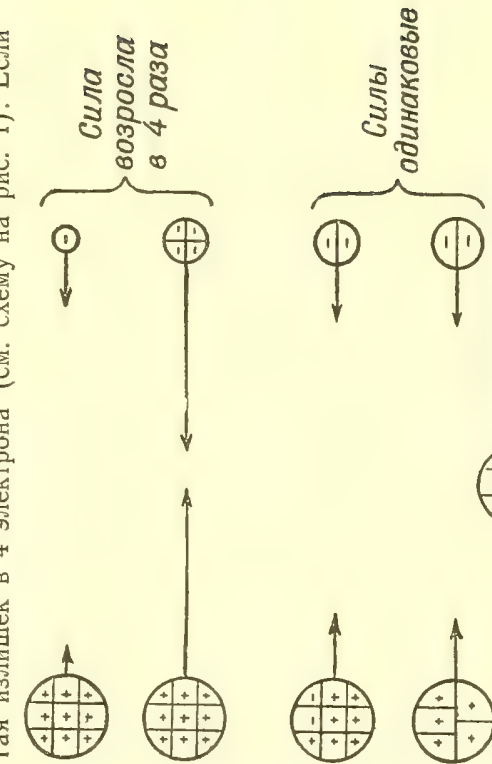

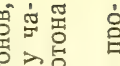

$=$ 읍

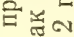

N

牙

뼝응

影

密要

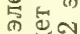

누유 열

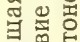

요

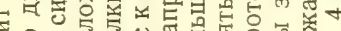

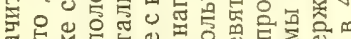

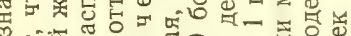

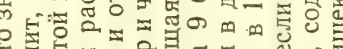

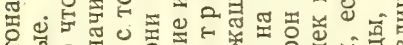

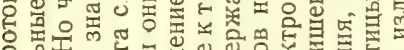

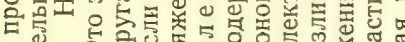
舟 की
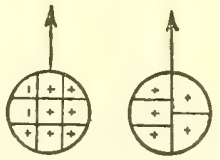

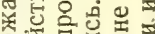

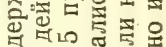

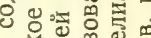

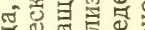

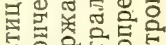

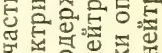

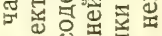

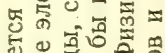

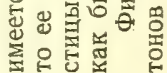

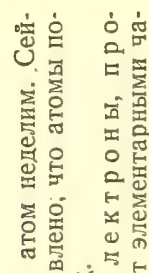

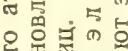

占㷊..

농

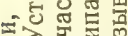

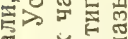

这茫

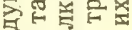

월 可

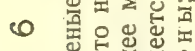

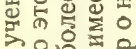

읜란

군

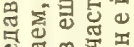

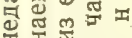

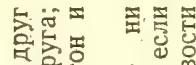

응용

荬的产

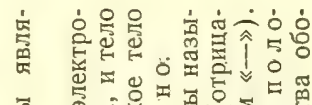

究竎운

战虽 옹

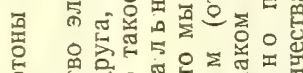

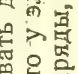

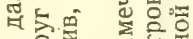

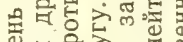

要虽会品思

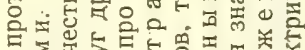

봉 त्

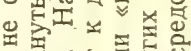

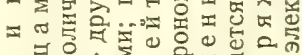

二

च

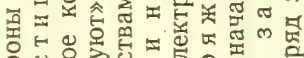

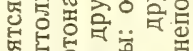

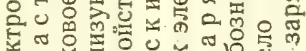

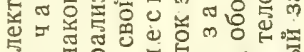

응은동키

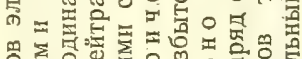

牙槆点

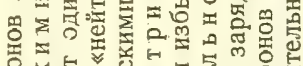

空恋

항 땡

工

영 㾍

突芯

을 웅

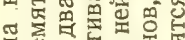

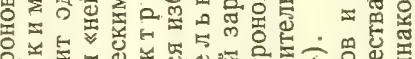

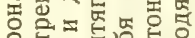

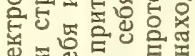

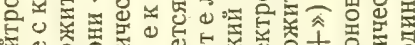

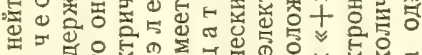

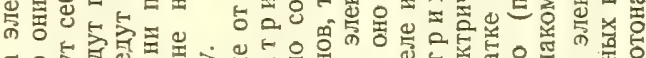

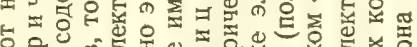

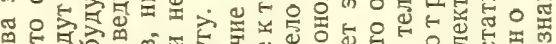

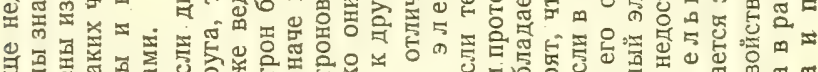

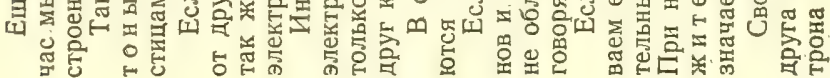




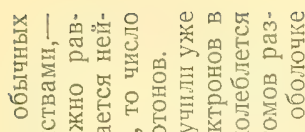

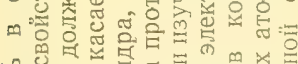

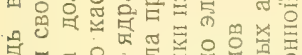

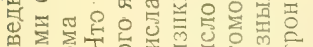

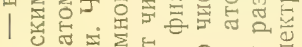

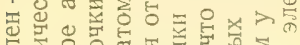

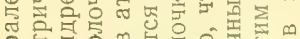

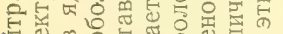
㖗号 出

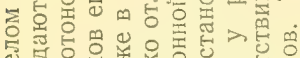

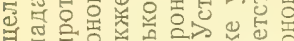
๓

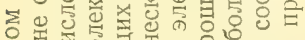

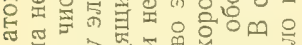

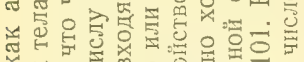

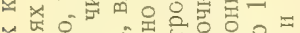

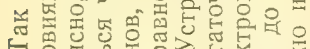

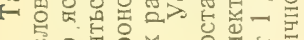

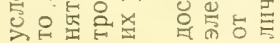

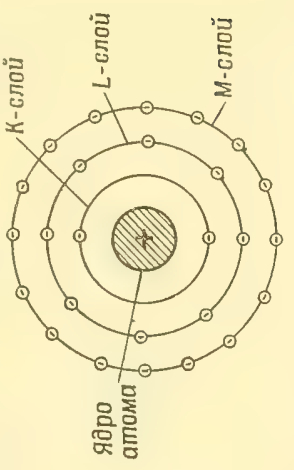

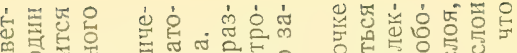

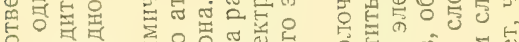

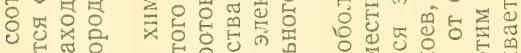

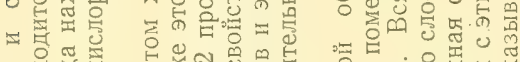

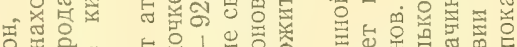

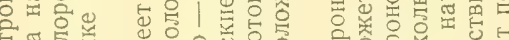

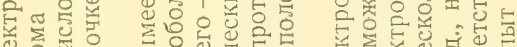

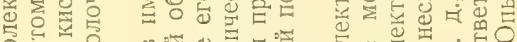

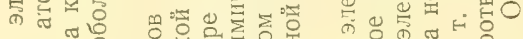

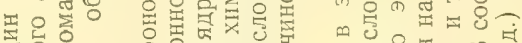

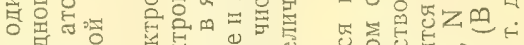

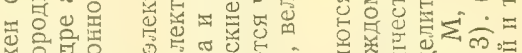

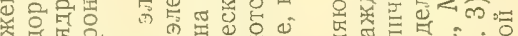

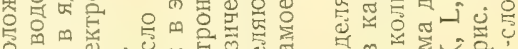

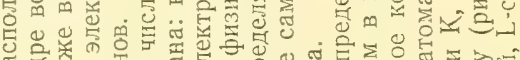
닷 口以

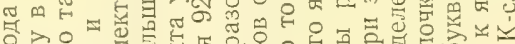
을일

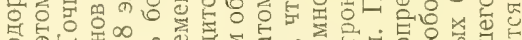
क๘

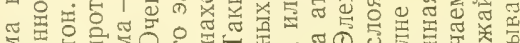

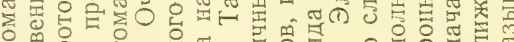

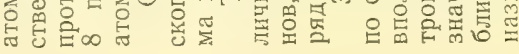

号

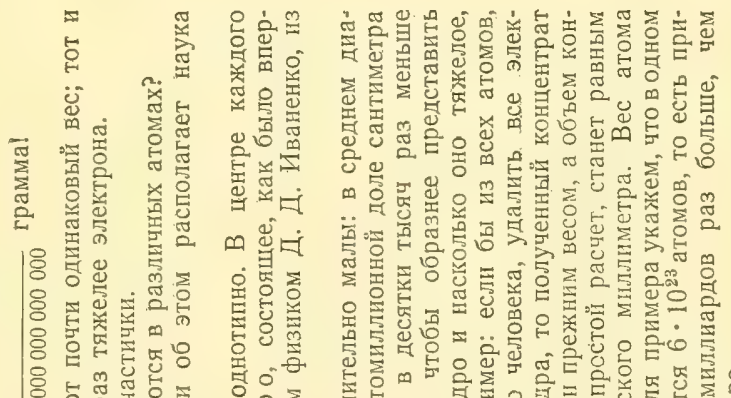

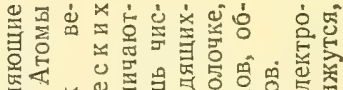

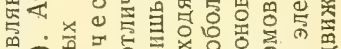

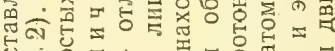

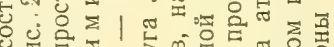

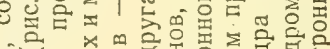

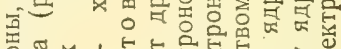
은 $1=5$ 들

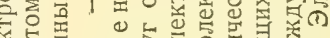

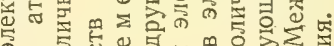

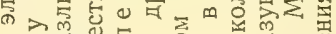

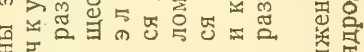

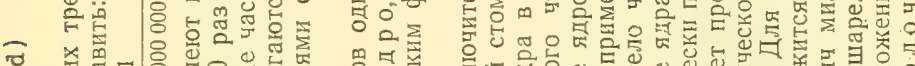
엉

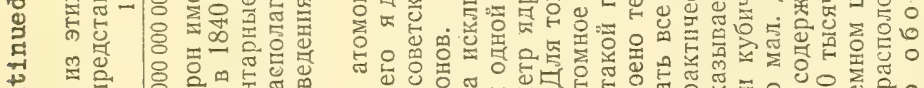

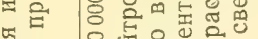

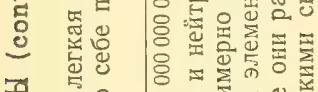

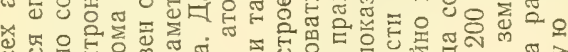

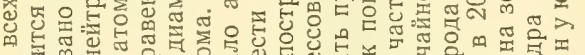

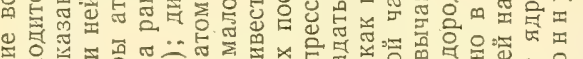
길 일

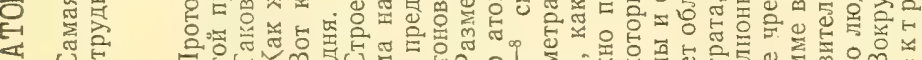
0 巡 는 눈 政

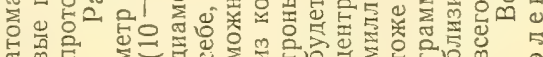

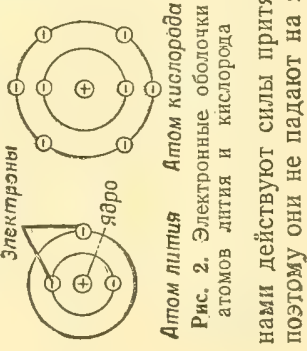


6 ATOMD (continued)

первый слой оболочки, непосредственно огружаюдий ядро, может вместить тольно 2 элентрона, второй - 8, третий - 18 и т. д.

Поясним это на примерах атомов кислороде и натрия. Ядро нислорода состоит из 8 протонов и 8 нейтронов. Его 8 электронов располоненн в двух өлентронных слоях: в первом 2 и во втором 6 . Второй элентронный слой остается немного незаполненным; он мог бы вместить еще 2 өлентрона. Ядро атома натрия имеет 11 протонов и 11 или 12 нейтронов. 11 әлектронов натрия распределены в трех элентронных слоях: в первом 2, во втором 8 и в третьем 1 электрон. В атомах легких элементов электроны могут быть в следующем электронном слое тольно тогда, ногна предыдуций слой заполнен.

\section{( А. И. Нитайгородсниіи, Строение вещества и его әнергия, стр. 8-12)}

\section{7 СИНДРОМ ДЕМЕНЦИИ}

Синдром деменции, слабоумия, харантерныи для грубо органических пораженйі мозга (прогрессивний паралич, сисилис мозга, артериосклероз мозга, опухоли, тянелые травматичесние поражения мозга), слагается в основном из нарушений памяти, внимания и критики. С умственньм упадком неизбенно связано сужение кругов интересов: низшие влечения (голод, половое чувство) нередно выступают при этом на первый план,не обузднваемне соображениями приличия, долга. От легких форм деменции ведут ступени н самнм тяжелим फормам полного разрушения всей психичесной деятельности; последнее нередно приходитсл наблюдать в исходннх стадиях прогрессивного паралича, ногда больные уже не тольно ничего не переживают и не соображают, но теряют дар речи, не могут самостоятельно есть, мочатся и испражняются под себя.

Иногда при местных, очаговнх поражениях мозга н дифбузным, т. е. общим, распространенним явлениям деменции присоединяется танже моторная или сензорная ас̆азия; это еще усугубляет психическую недостаточность и беспомощность таних больних.

Особо следует упомянуть своеобразную форму деменции в виде так называемого амнестичесного синдрома (корсаковсного), ногда в первую очередь поражается способность запоминания при сравнительной сохранности пругих психических функций. бти больные не в состоянии запомнить ничего нового, например, свое место за столом, палату, нойку, время дня, бамилию врача.

Они не запоминают последних впечатленй, но в то же время могут хорошо помнить все, что насается детства, отрочества, шнольных знаний. Провалы памлти эти больнне часто заполняют так назнваемыми конфабуляциями, т. е. вымнслом, сочинительством. На вопрос о том, что он делал сегодня, больной, например, заявляет: "Јетал на аэроплане". бтот синдром особенно часто наблюдается у старых алноголиков (см. о синдроме Корсанова в главе "Полиневрит"), а танще при сенильных психозах, после тяжельх травматичесних поражений мозга.

(В.В. Михеев и А. В. Нейман, Нервнне и психичесиие болезни, стр. 108-109) 


\title{
8 РЕФЕРАТИВН ЫЙ ЈКУРНА $\Lambda$ Х И М И
}

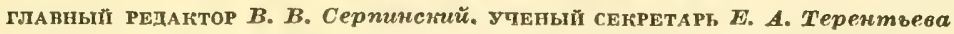
РУКбводИТЕЛИ СЕКтоРов: Д. А. Бочвар, В. В. Ка.барџя, В. Л. Кретович, Д. Н. Курсанов, К. С. Топииев, Н. А. Фукс

Рефераты 76295- 79039 스 $24 \quad 25$ декабря 1957 г。

\section{ОБЩИЕ ВОПРОСЫ}

\section{МЕТОДОЛОГИЯ. ИСТОРКЯ. НАУЧНЫЕ УЧРЕЖДЕНИЯ И КОНФЕРЕНЦИИ. ПРЕПОДАВАНИЕ. ВОПРОСЫ БИБЛИОГРАФИИ И НАУЧНОП ДОКУМЕНТАДИИ}

\author{
Редактор Д. И. Тумаркин
}

76295. Успехи органической химпи на Украпне за 40 лет Советской власти. К и п и а н в А. И., Укр. хим. ж.. 1957, 23, № 4 4, 460-473

76296. Химн в советской школе за сорок лет. II а рмено в К. Я., Химия в школе, 1957, № 5, 50-60

76297. Успехи химизации сельского хозяйства СССР. Б а р а н о в П. А., Удобрение и урожай, 1957, № $9,1-18$

76298. Кинопленочная промышленность к 40-летию Великого Октября. К а ли ик и и А., Техника кино и телевидения, 1957, № 9, 1-12

76299. Определения атомных весов русскими химикамп в XIX в. (до 1869 г.). Ф пг у р в с к й й Н. А., К у р и п н о й В. И., Ж‥ физ. химиц, 1957, 31, № 6, $1429-1433$ Библ. 41 назв.

A. T.

76300. Электрохимические законы Фарадея и определение эквивалентных весов. Э л, И д е (Faraday's electrochemical laws and the determination of equivalent weights. Ehl Rosemary Gene, I hde $\mathrm{A}$ a a $\mathrm{r}$ o $\mathrm{n}$ J.), J, Chem. Educ., 1954, 31, № 5, 226-232 (англ.)

Законы Фарадея (1834) почти полностью игнорировались в науке до 1880 г. Первое их использование для определения хим. әквивалентов относится ко времені после 1873 г. Причиной автор считает авторитет Берцелиуса, выступившего с критикой эксперцментов Фарадея и до конца своей жизни (1848) не признававшего достовернссти этих законов. Приведены сведения об итальянском исследователе-электрофизиологе Карло Маттеучци (1811-1868), цзучавшем хим. действие әлектрич. тока и опубликовавшем в 1835 г. выводы, аналогичные законам Фарадея; обсуждается вопрос о приоритете.

Ю. Вендельштейн 76301. Вклад Инии в развитие пеорганической химии. M exт a (India's contribution to inorganic chemistry. Meht a S. M.), Sci, and Culture, 1957, 23, № 1, 5-11 (англ.)

Краткий иеторич. очерк по периодам: до XIX в.; XIX в.; $1901-1920 ; 1921-1940 ; 1941-1955$.

Д. T.

76302. Основные этапы развития общей, неорганической и физической химит на Украине (до 1917 г.). тур ченко Я. И. (Основні етапи розвитку загальної неорганінної $\mathrm{i}$ фізичної хімії на Україні (до 1917 р.). Т у р q в н к о Я. I.), Наршоп в історії техн. АН УРСР, 1957, вип, 4, 25-46 (укр.)
76303. Пз ранней истории физиологической химии в Германик. 3 х м м р (Aus der Aufängen der physiologischen Chemie in Deutschland. Si m mer $\mathrm{H}$ a n s), Sudhoffs Arch. Geschichte Med. und Naturwiss., 1955, 39, № 3, 216-236 (вем.)

Биографические сведения й очерк научной деятөльности Георга Карла Людвига Зикварта (17841864) пи Юлиуса Эйгена Шлоссбергера (1819-1860) в 'Гюбингенском ун-те. Очерк возникновения и развития псследовательской п учебной работы по физиологй. химии в Тюбингенском ун-те-в XIX в. Д. Т. 76304. Столетие печи Симена. Скофилд (Centenary of the Siemens furnace. S c h of ield M.), Glass, 1957, 34, № 1, 26 (англ.)

Краткая справка об истории изобретения Карлов Вильгельмом (Чарльзом Вильямом) Сименсом регеноративной печи, примененной для варки стекла.

76305. Развитие Н. Павлушкин

Б а у р (Welche лаков. Исторкческое обозрение. historischen Anregungen können wir aus einer ckes gewinn? ckes gewinnen? B a u r P.), Farbe und Lack, 1956, 62, № $11,513-528$ (нем.)

Технические и историч. сведения о лаках и искусстве лакировки в Восточной Азии (Китай, Япония, Сиам) с древних времен и о начальном периоде произ-ва лаков в Европе. Приведены репродукция (21). Библ. 18 назв.

Б. Шемякив

76306. Роль ученых Петербурга - Ленинграда в развитй химической науки. Н и ко льскй В. П., В сб.: Химия. Л., Госхимиздат, 1957, 7-20

76367. Химическая промышленпость Петербурга. (Краткий очерк). А в ерьян о в Н. Н., В сб.: Химия. Л., Госхимиздат, 1957, 21-37

76308. Завод «Красный Химик» («Тентелевский») и его вклад в развитие химпческих производетв. II м ек к е Я. М., Ч е р в я. М. А., В сб.: Химия. Л., Госхимиздат, 1957, 68-73

76309. Развитие керамики в Петербурге - Левинграде. А в у стинии ия А. И., В сб: Строит. материалы. Л., Гос. изд-во лит. по стр-ву и архитект., $1957,75-84$

Исторический очерк.

д. T.

76310. Первый фарфоровый завод в Россив. С о к ол о Е А. С., В сб.: Строит. материалы. Л., Гос. изд-во лит. по стр-ву и архитект., 1957, 104-119

Очерк историі возниквовевия и развития фарфоро- 
уменьпается. Для әксперим. исследования процесса осаждения пастиц из струи провзводилось фотографирование траекторий тастиц; благодаря слегка цилипдрич. форме П получалось резкое пзображение еө профпля. Результаты подтвердпли приближенную теорвю осаждения частиц из струи и позволили вывести ф-лы, достатоцные для приближенного коэф. захвата кониметра.

выписления В. Дунский

Cм. также: раздел Химия высокомолекулярных соединений п реферат электромикроскопич. исслед. коллопдов 76908

\title{
НЕОРГАНИЧЕСКАЯ ХИМИЯ. КОМПЛЕКСНЫЕ СОЕДИНЕНИЯ
}

\author{
Редактор A. Б. Нейдинг
}

76784. Современная неорганическая химия в свете пей Д. И. Менделеева. Щ у к а р в С. А., Ж. нөорганич. химии, 1957, 2, № 4, 713-718

76785. Отделение цинка от алюминкя методом ионного обмена. Ц и н д е в п Е. П., Веств. Моск. ун-та. Сер. матем., механ., астрон., физ., химин, 1957, № 1, $150-155$

Исследовано поведение $\mathrm{Zn}$ ㄱ $\mathrm{Al}$ на катионитө «CБC》 в присутствпи винной, сульфосалициловой и щавелөвой к-т, а тањже в присутствии пирогаллола и глицерина. На основании раздичной устойчивости комплексных соединений указанных органич. реактивов с $\mathrm{Zn}$ п Al разработаны методы колич. разделения последних. Установлено, тто наиболее удобными комдлексообразующимп в-вамп для разделения смесп Al и $\mathrm{Zn}$ являются винная, сульфосалцциловая п павелевая к-ты.

Резюме автора

76786. Ошистка п физические свойства ртути. Г ордон, У п т ер (Purification of mercury and its physical properties. Gord on $\mathrm{Ch}$ arles $\mathrm{L}, \mathrm{W}$ ichers Ed ward), Ann. N. Y. Acad. Sci., 1957, 65, № 5, $369-387$ (англ.)

Обзор. Библ. 132 назв.

B. III.

76787. Хшмия лантанидов. М п с у м п (ランタニド 素の化 學。三角省三), 化學と工業, Кагагу то когё, Chem. and Chem. Ind., 1957, 10, № 3, 1.18-128 (японек.)

Обзор. Бпбл. 100 назв.

M. M.

76788. Редкоземельные элемекты тулий п прометиі приобретают техническую ценность. Ко г н Б. П., Цветн. металлы, 1957, 추 6, 92-95

Обзор вностравной литературы. Бкӧл. 20 назв. В. III.

76789. Исследовапе реақцй взаммодействия твердых веществ. К вотросу о полученши крксталлического судьфнда висмута. Г ли т ен Воронежск. ун-та, 1956, 40, 23-29

Изучены гетерог. р-цди в системе твердое в-во - p-p I получөны разпчные образды кристаллич. $\mathrm{Bi}_{2} \mathrm{~S}_{3}$ в лабор. условпях. Кднетич. грлвые пзученных р-ций имөют ясно выраженный максимум, характерный для топохим. р-ций. Внешняя форма получеввых жристаллов $\mathrm{Bi}_{2} \mathrm{~S}_{3}$ соответствует внешней форме пстодных твердых в-в. Резюме автора 76790. Гидратк двуокиеп титана. К а с и о в А. К.,

Изв. АН КазССР. Сер. хим., 1956, вып. 10, 10-21

$\mathrm{TiO}_{2}$ с водой образует $\mathrm{H}_{2} \mathrm{TiO}_{3}$ п $\mathrm{H}_{2} \mathrm{Ti}_{2} \mathrm{O}_{5}$. $\mathrm{H}_{2} \mathrm{TiO}_{3}$ образуется при взаимодействии $\mathrm{Ti}\left(\mathrm{SO}_{4}\right)_{2}$ с $\mathrm{NH}_{3}$ в водн. p-pax на холоду, а также при гидролизө $\mathrm{TiCl}_{4}$ при комнатной т-ре. Образование $\mathrm{H}_{2} \mathrm{Ti}_{2} \mathrm{O}_{5}$ наблюдается прг гидролизе $\mathrm{Ti}\left(\mathrm{SO}_{4}\right)_{2}$ в пвтервале $\mathrm{T}-\mathrm{p} \quad 60-100^{\circ}$. Титавовая к-та, осаждевная цз р-ров солей Ті действием щелочей пли гидролизом п проявляющая свойства a-кислоты, представляет собой по состару $\mathrm{H}_{2} \mathrm{TiO}_{3}$, а титановая к-та, осажденная из $\mathrm{Ti}\left(\mathrm{SO}_{4}\right)_{2}$ при нагреванпи гі обладающая свойствами $\beta$-кислот, $-\mathrm{H}_{2} \mathrm{Ti}_{2} \mathrm{O}_{5}$. Обе эти к-ты являнтся индивидуальными соедшнениями. $\mathrm{H}_{2} \mathrm{TiO}_{3}$ п $\mathrm{H}_{2} \mathrm{Ti}_{2} \mathrm{O}_{5}$ представляют прочные соединенкл, выдөржквающие нагревание под слоем воды прг $100^{\circ}$. В процессе старения $\alpha$-титановая к-та пероходит в $\beta$-тптановуг к-ту п утрачивает способность растворяться в разб. неорганич. К-тах, но по своему составу не цзменяется. Нө обнаружено существование к-ты состава $\mathrm{H}_{4} \mathrm{TiO}_{4}$. Из резюме автора 76791. Псследование іоодшдого метода рафинированця циркония. Факторы, влияющие на скорость процесса рафинирования. Елельлно в В. С.,

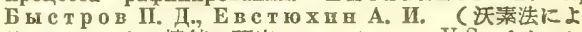
るシルコニウム精鍊の研究.エメy+ーノフV.S..ブイスト ロフ P.D., エフスチュヒンA. I.), 原子エネルキ, Атомн. энергия, Гәнсп энәругк, 1956, 1, № 1, 56-67 (японск.) Перевод. См. РЖКХим, 1956, 68069.

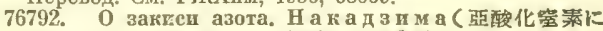

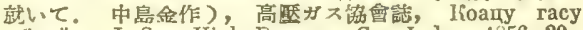
кёкайси, J. Soc. High Pressure Gas Ind., 1956, 20, № 7, 13-17 (японск.) Обзор. Бгбл. 29 назв. 76793. Электролитическое восстановление азотной кислоты до гироксиламина. Часть I. P а м а с в а м в (Electrolytic reduction of nitric acid to hydroxylamine. Part I. $\mathrm{R}$ a $\mathrm{m}$ a s w a $\mathrm{m}$ y D.), J. Scient. and Industr. Res., 1957, BC16, № 3, B128-B131 (англ.)

Описан мөтод получения $\mathrm{NH}_{2} \mathrm{OH}$ әлектролитич. восстановлением p-pa $\mathrm{HNO}_{3}$ c $\mathrm{Pt}$-анодом ㅍ $\mathrm{Hg}$-катодом в присутствии $\mathrm{Na}_{2} \mathrm{SO}_{4}, \mathrm{NaNO}_{3}$ пли $\mathrm{NaCl}$. Анолитом служнтт $15-20 \%$-ный $\mathrm{Na}_{2} \mathrm{SO}_{4}$. При оптимальных условиях: конц-ии $\mathrm{HNO}_{3} 1,15$ п., конц-ии $\mathrm{Na}_{2} \mathrm{SO}_{4} 10 \%$, т-ре $0-20^{\circ}$ в присутствии катализаторов $(0,001-0,002 M$ солей Th плг $\mathrm{Fe}$ пли $0,025 M$ мочевпны) выход по току превышает $90 \%$. В качестве побочных продуктов образуготся $\mathrm{HNO}_{2}, \mathrm{H}_{2} \mathrm{~N}_{2} \mathrm{O}_{2}, \mathrm{NH}_{3}, \mathrm{~N}_{2} \mathrm{O}_{2}, \mathrm{~N}_{2}$ и др. Каталштич. дөйствие мочевпны показывает, пто $\mathrm{HNO}_{2}$ нө является промекуточным иродуктом при восстановленип. Очевидно, внатале пропсходит образованшө $\mathrm{Na}$ по схемө $6 \mathrm{Na}+$ әлектролгз) $6 \mathrm{Na}+6 e$, затем $\mathrm{Na}$ дает с $\mathrm{Hg}$-катодом амальгаму. Амальгама Na восстанавливает затем азотную к-ту: $6 \mathrm{Na}(\mathrm{Hg})+\mathrm{HNO}_{3}+4 \mathrm{H}_{2} \mathrm{O}=\mathrm{NH}_{2} \mathrm{OH}+6 \mathrm{NaOH}$. Прибавленный к әлектролиту $\mathrm{Na}_{2} \mathrm{SO}_{4}$ служит источнвком ионов $\mathrm{Na}+$ и, громе того, увеличивает әлектропроводность.

И. Словим

76794. О продуктах взаимодействия пентахлоридов таптала и пиобия с хлорокшсью фосфора. Н г се л bс о н. А., Ж⿱ неорганцч. химии, 1957, 2, № 4, 816-819 Установлено, пто при действй пзбытка $\mathrm{POCl}_{3}$ на пентахлориды Та п् $\mathrm{Nb}$ образуются комплексные соединения, состав которых ответает ф-ле $\mathrm{Ta}(\mathrm{Nb}) \mathrm{Cl}_{5} \cdot \mathrm{POCl}_{3}$. При нагреваниг указанных соединений провсходит отщөплевие пасти $\mathrm{POCl}_{3}$, пока не образуются продукты, перегоняющиеся без изменения состава. Хим. анализ этих продуктов, перегоняющихся при атмосферном давлени, дал для Та-продукта стношениө Тa $: \mathrm{P}=1,22: 1$, п् для $\mathrm{Nb}$-продукта $-\mathrm{Nb}: \mathrm{P}=1,49: 1$. Найдено, что перегоняющйся Та-продукт плавштся в пнтервале $129-133,5^{\circ}$, а Nb-продукт $120,5-131^{\circ}$. T. кип. Та-продукта составляет $\sim 285^{\circ}$, a Nb-продукта $\sim 263^{\circ}$ прц атмосферном давлении. Из резюмө автора 


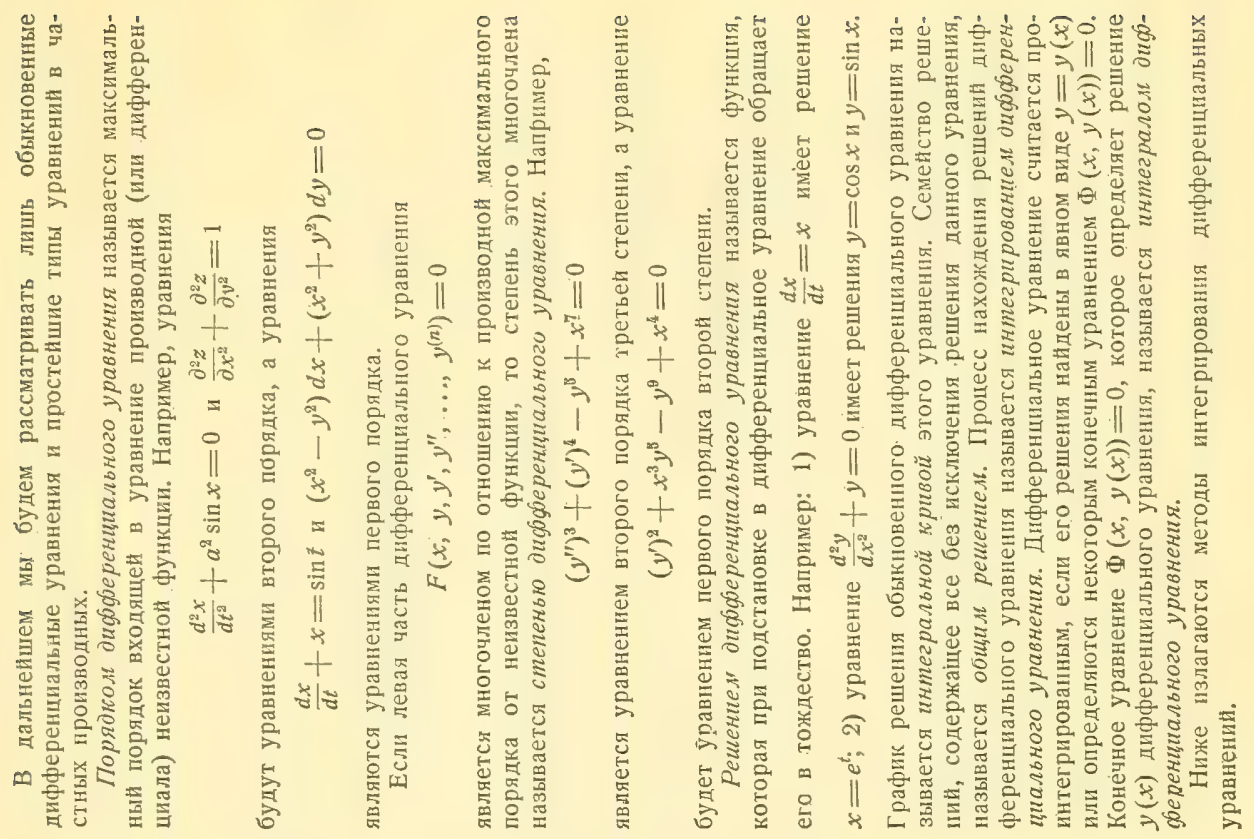

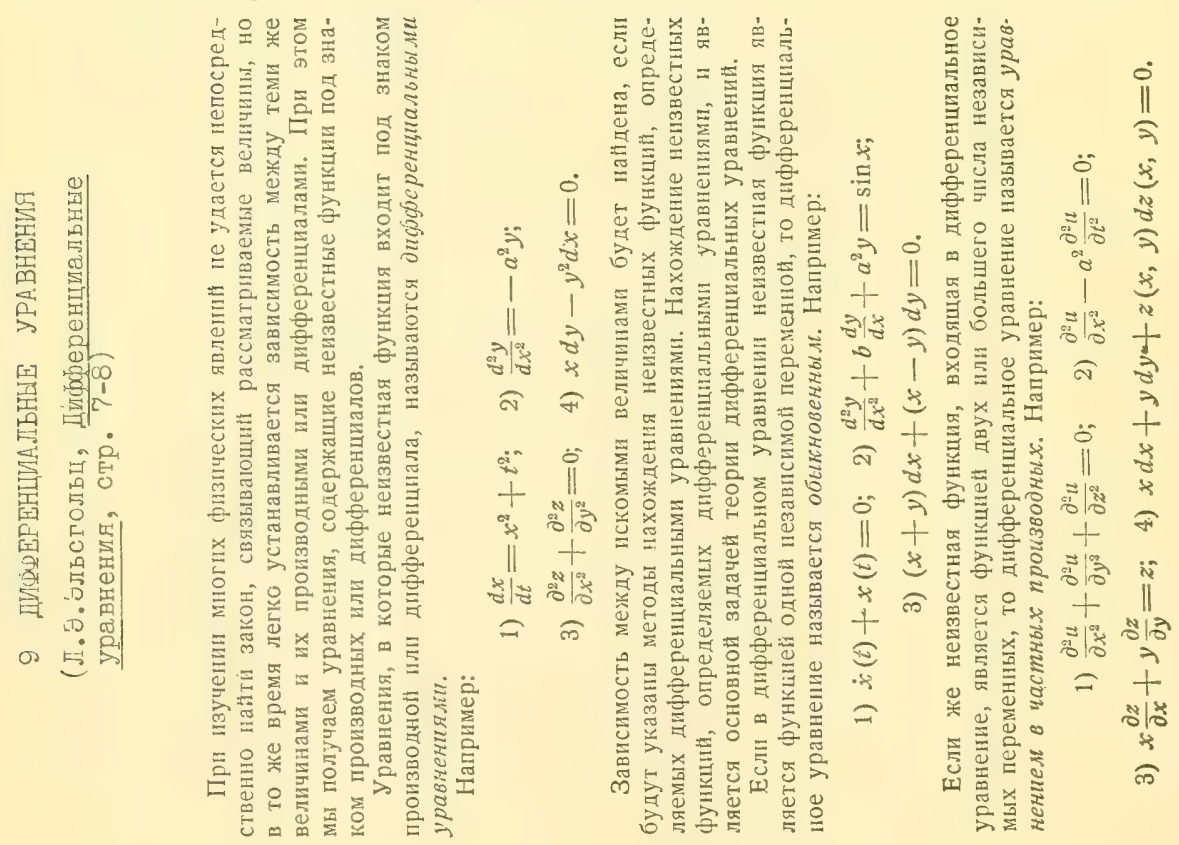




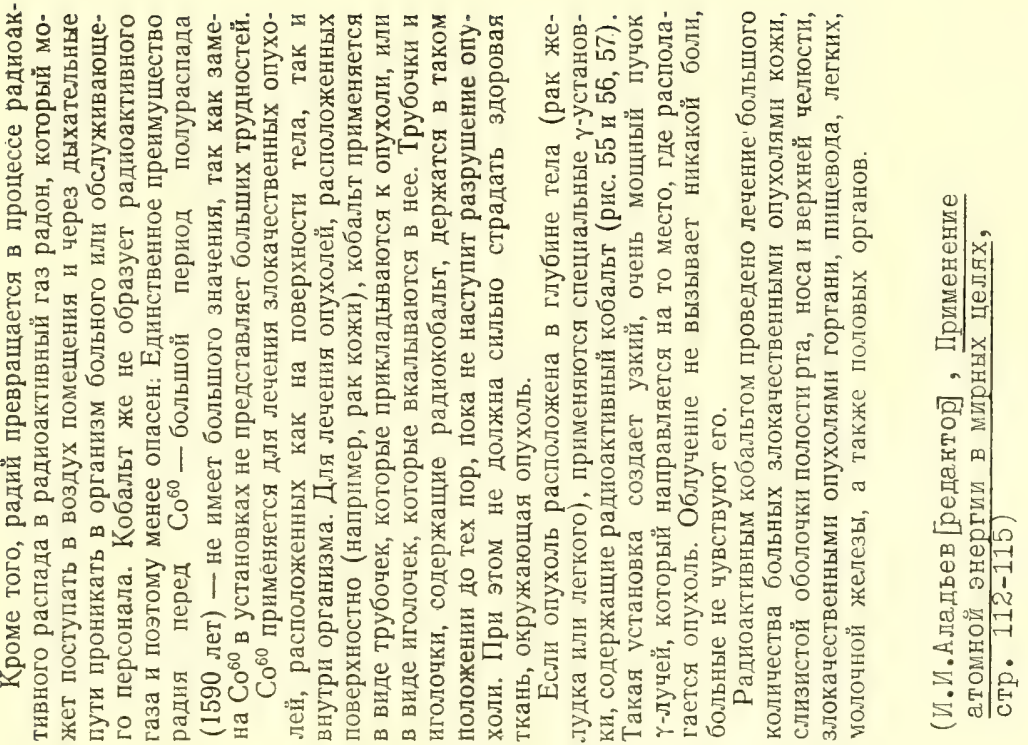

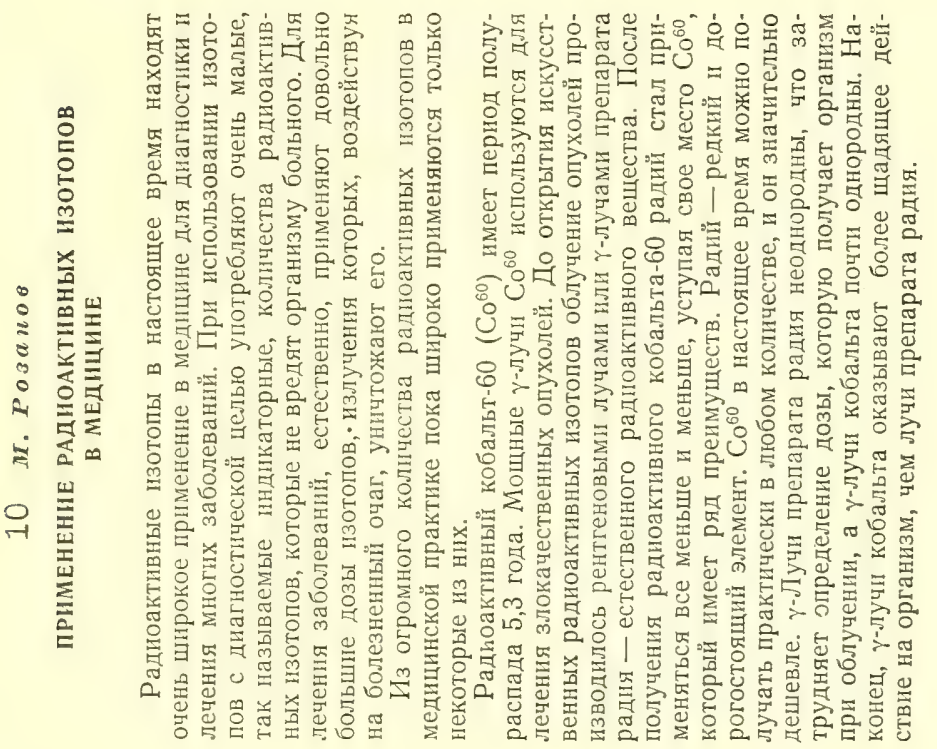




\section{SECTION VI (continued)}

\section{$\underline{\text { Russian-English Glossary }}$}

This glossary contains the traditional dictionary-entry forms for all the words used in the foregoing texts. Care has been taken to cite the most relevant meanines for the words, but it will no doubt happen that a specialist may substitute more exact terminology in a text dealing with his particular field. The author would appreciate any suggestions for more exact renderings of particular Russian terms.

In the glossary, the following grammatical information is available:

Nouns

Gender is indicated for the nouns only when the nominative singular form ends in the soft sign(b). Otherwise, singular nouns are

masculine, if terminated by a consonant:

neuter, if the final letter is the vowel -o or -e

feminine, if the final letter is -a or $-g$

The genitive singular form is cited for those nouns which have the added vowel -o- or -e- in the nominative singular.

Verbs

The 3rd. singular form of the "present" is given in parentheses, when its fomation would not be obvious from inspection of the infinitive. Aspect is indicated by explicit labelling of the perfective verbs.

\section{Prepositions}

The case or cases of nouns and adjectives associated with a preposition are indicated in parentheses after the preposition.

\section{Accent}

A word with no accent marking has the stress accent on the first syllable. The letter $e$ with two dots(ë) symbolizes the place of the accent. An acute accent mark(') indicates the place of accent, when it is not so indicated by the first two devices. below:

The abbreviations used throughout this manual and in the glossary are summarized

$\begin{array}{ll}\text { masc. } & \text { masculine } \\ \text { neut. } & \begin{array}{l}\text { neuter } \\ \text { feminine }\end{array} \\ \text { sf. } & \text { singular } \\ \text { pl. } & \text { plural } \\ \text { adj. } & \text { adjective } \\ \text { prep. } & \text { preposition } \\ \text { ppl. } & \text { participle } \\ \text { pf. } & \text { p.rfective aspect } \\ \text { impf. } & \text { imperfective aspect } \\ \text { N } & \text { nominative } \\ \text { A } & \text { accusative } \\ \text { G } & \text { genitive } \\ \text { D } & \text { dative } \\ \text { P } & \text { prepositional } \\ \text { I } & \text { instrumental }\end{array}$


A a

\begin{tabular}{|c|c|}
\hline $\begin{array}{l}\text { a } \\
\text { абстра́ктний }\end{array}$ & $\begin{array}{l}\text { and, but } \\
\text { abstract }\end{array}$ \\
\hline автор & author \\
\hline авторите́т & authority \\
\hline адиабати́чесний & Adiabatic \\
\hline Зия & Asia \\
\hline aзóm & nitrogen \\
\hline азо́тный & nitric \\
\hline анапе́мик & academic (a title) \\
\hline акаде́мия & academy \\
\hline КТйвный & active \\
\hline алкого́лик & alcoholic \\
\hline алюми́ний & aluminum \\
\hline амальга́ма & amalgam \\
\hline амнести́ческий & amnestic \\
\hline AH= Ана.пе́мия наууи & Academy of Sciences \\
\hline англййский & English \\
\hline ангстрем & angstrom \\
\hline QHOF & anode \\
\hline нолит & anolyte \\
\hline артериоснлеро́з & arteriosclerosis \\
\hline астроно́ & astronomer \\
\hline астрономия & astronomy \\
\hline aTOM & atom \\
\hline ล.TOMHHЙ & atomic \\
\hline ๖а́зия & aphasia \\
\hline оопла́н & plane \\
\hline
\end{tabular}

B 6

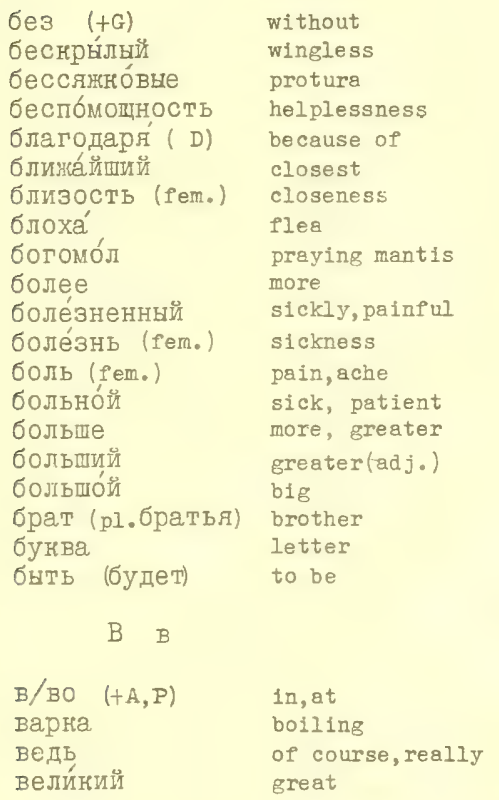

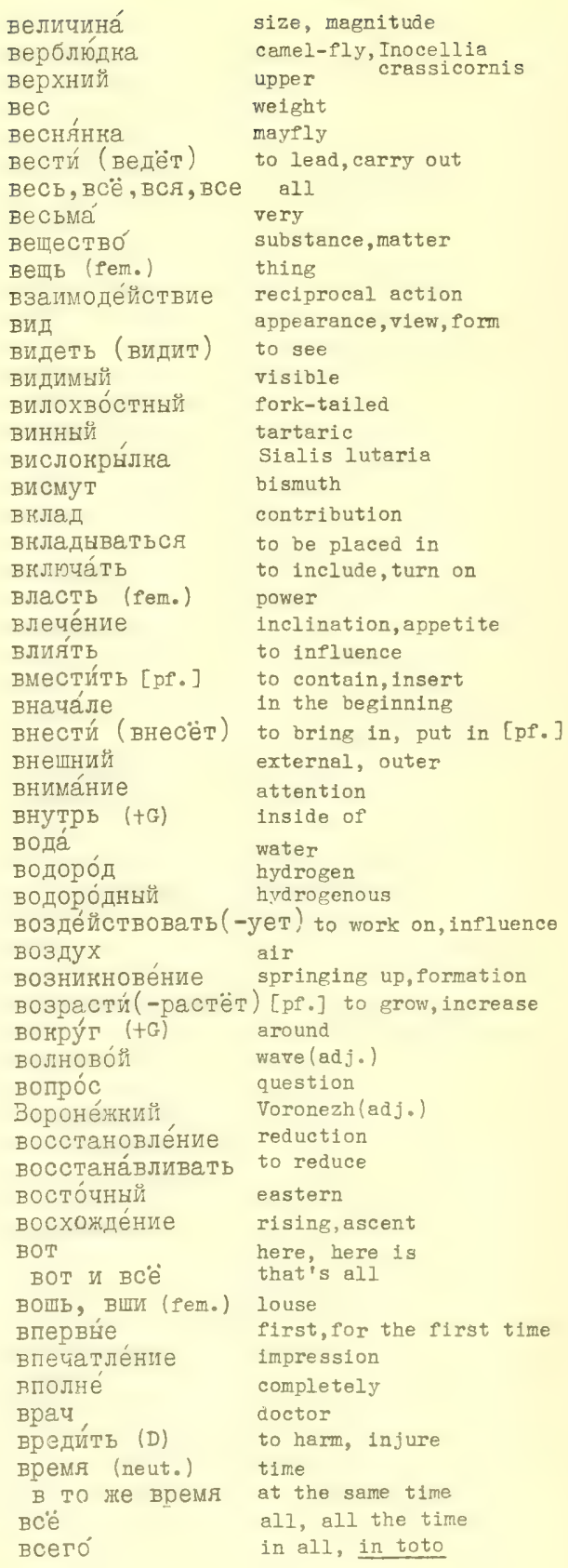




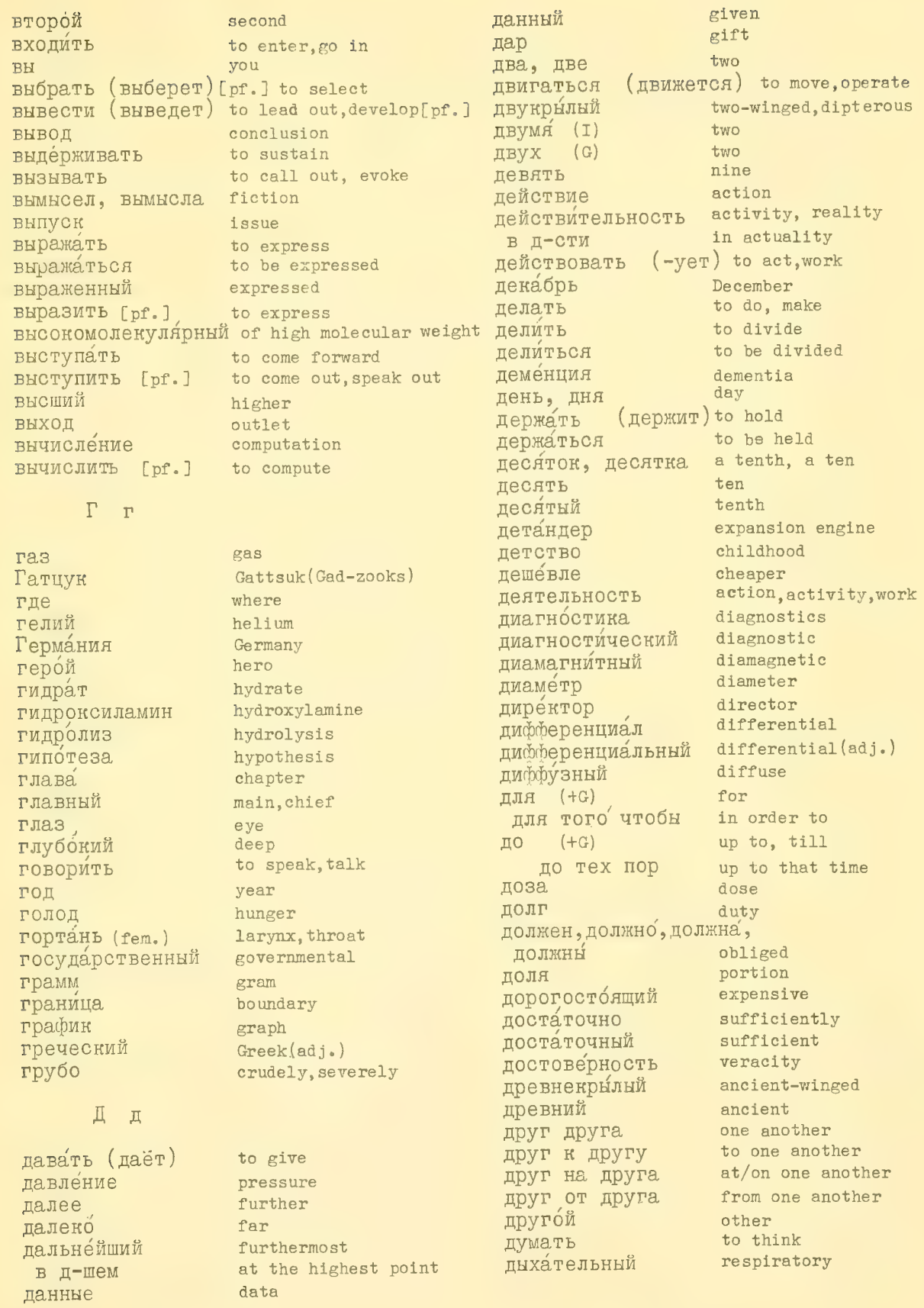




$$
\stackrel{\mathrm{E}}{\mathrm{E}} \stackrel{\mathrm{e}}{\mathrm{E}}
$$

$\begin{array}{ll}\text { Евро́па } & \text { Europe } \\ \text { его́ } & \text { his, its } \\ \text { его́ } & \text { him, it } \\ \text { еди́ница } & \text { unit } \\ \text { еди́нстенныһ } & \text { single } \\ \text { её } & \text { her, its } \\ \text { ё̈ } & \text { her, it } \\ \text { если } & \text { if } \\ \text { если бн } & \text { if [unreal condition] } \\ \text { есте́ственно } & \text { naturally } \\ \text { есте́ственный } & \text { natural } \\ \text { есть } & \text { is } \\ \text { есть } & \text { to eat } \\ \text { ещё } & \text { still, yet }\end{array}$

$$
\text { 瓷 }
$$

$\begin{array}{ll}\text { же } & \text { but, now } \\ \text { желу́док, желудка } & \text { stomach } \\ \text { жидкий } & \text { fluid, liquid } \\ \text { жидкость (fem.) } & \text { liquid } \\ \text { жизнь (fem.) } & \text { life } \\ \text { жите́йспий } & \text { worldly, life(ad.) } \\ \text { жун } & \text { beetle } \\ \text { журна́л } & \text { magazine,journal }\end{array}$

\begin{tabular}{|c|c|}
\hline $3 a$ & behind, for, during \\
\hline заболева́ние & illness \\
\hline Вйсимость (fem.) & dependence, correlation \\
\hline зод & plant, factory \\
\hline ада́ча & task, problem \\
\hline акись & oxide \\
\hline $\mathrm{aHOH}$, & law \\
\hline анономерность & regularity \\
\hline аме́на & substitution \\
\hline амечать & to notice \\
\hline апо́лненный & filled \\
\hline апо́лнить [pf.] & to fill \\
\hline аполня́ть & to 1111 \\
\hline апомина́ние & recollection \\
\hline апомина́ть & to remember \\
\hline апо́мнить [pf.] & to remember \\
\hline аря́д , & charge \\
\hline арядить [pf.] & to charge \\
\hline аря́женный & charged \\
\hline аста́вить [pf.] & to force \\
\hline $\begin{array}{l}\text { Tем } \\
\text { трудня́ть }\end{array}$ & thereupon \\
\hline $\begin{array}{l}\text { трудня́ть } \\
\text { хва́т }\end{array}$ & to make difficult \\
\hline $\begin{array}{l}\text { ахват } \\
\text { ахонде́ние }\end{array}$ & $\begin{array}{l}\text { hold, fastening } \\
\text { descent }\end{array}$ \\
\hline zuéN & why \\
\hline АЯВЈ, Я́ть & to announce, declare \\
\hline доровнй & healthy \\
\hline еме́льннї & terrestrial, land (adj \\
\hline
\end{tabular}

\section{3}

$\begin{array}{ll}\text { земля' } & \text { earth, land, ground } \\ \text { земно́й } & \text { earthly, terrestrial } \\ \text { злока́чественный } & \text { malignant } \\ \text { знак } & \text { sign, symbol } \\ \text { знание } & \text { knowledge } \\ \text { знать } & \text { to know } \\ \text { значе́ние } & \text { meaning } \\ \text { значйтельно } & \text { significantly } \\ \text { значить } & \text { to mean }\end{array}$

И И

и
и
иго́лочна
иде́
из (+G)

and

even, still, also needle (diminutive) idea out of, from избы́ток, избытна surplus, excess изве́стие news изве́стны得 known, well-known изда́тельство publishing house излага́ться to be explained изли́шек излуче́ние измене́ние изменя́ться измере́ние изме́рить [pf.] измеря́ть изображе́ние изобрете́ние изобретённыи изото́п изуча́ть изуче́ние изучченный изучи́ть [pf.] или

им (I) име́ть (име́ет) име́ться ина́ чe индивидуа́льный ин ди на́ т орный

Индия

ине́рция

иногда́

ино́й

иностра́нный институ́т интегра́л интегра́льный интегри́рование интерва́л интерес ио́ннแй исключе́ние исключи́тельно исно́мый emission, radtation change to be changed measuring, measurement to measure to measure picture, image discovery, invention discovered, invented

isotope to study study studied to study or by him, by it to have to be had otherwise individual (adj.) indicator (adj.)

Ind 1 a

inertia sometimes some, other foreign institute integral integral (adj.) integration interval

interest ionic exception exceptionally unknown, what is being sought 


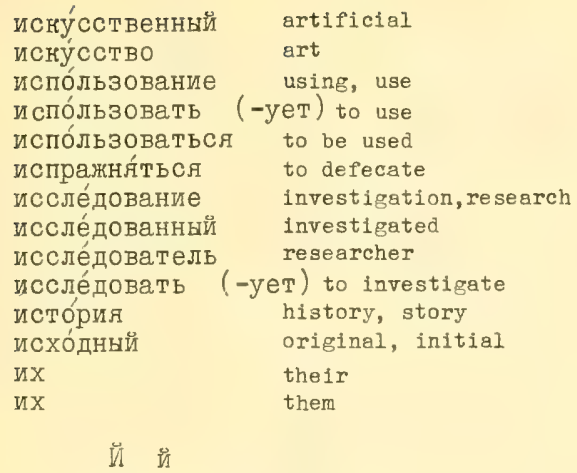

йоди́дный iodide (adj.)

K $\mathrm{K}$

\begin{tabular}{|c|c|}
\hline$K \quad(+D)$ & to, towards \\
\hline каждый & each, every \\
\hline паK & how, as, like \\
\hline нан бн & as though \\
\hline как...так и & both... and... \\
\hline накой & what kind of \\
\hline налендарь (masc.) & calendar \\
\hline каса́ться & to concern \\
\hline натализа́тор & catalyzer \\
\hline катионит & cationic exchange resin \\
\hline нато́д & cathode \\
\hline начество & quality \\
\hline в начестве & like, as \\
\hline нера́мика & ceramics \\
\hline нилогаусс & kilogauss \\
\hline кино́ & movie \\
\hline киноплёночный & movie sound track(adj.) \\
\hline нислоро́д & oxygen \\
\hline кислоро́дннй & oxygenous \\
\hline нислота́ & acid \\
\hline Кита́й & China \\
\hline книжна & book, booklet \\
\hline нобальт & cobalt \\
\hline когда́ & when \\
\hline коже & skin \\
\hline койка & $\cot$ \\
\hline $\begin{array}{l}\text { колеба́ться (ноле } \\
\text { ноли́чественный }\end{array}$ & $\begin{array}{l}\text { блется) to shake } \\
\text { quantitative }\end{array}$ \\
\hline коли́чество & quantity \\
\hline колло́ид & collotd \\
\hline коло́нна & column \\
\hline юомната & room \\
\hline номнатный & room $(a d j$.$) , indoor$ \\
\hline номпле́ксньй & $\begin{array}{l}\text { complex, complete } \\
\text { end }\end{array}$ \\
\hline $\begin{array}{l}\text { нонец, жонца } \\
\text { ноне́чный }\end{array}$ & final, finite \\
\hline нониме́тр & konometer \\
\hline
\end{tabular}

\begin{tabular}{|c|c|}
\hline онцентрат & concentrate \\
\hline нонсоб бу ля́ция & confabulation \\
\hline норсано́вский & Korsakov (adj.) \\
\hline освенный & indirect \\
\hline ното́рнй & which, who \\
\hline $\begin{array}{l}\text { ноэфф̆цциент } \\
\text { ноэ Һбицие́нтньй }\end{array}$ & $\begin{array}{l}\text { coefficient } \\
\text { coefficient(adj.) }\end{array}$ \\
\hline красннй & red \\
\hline нраткий & short \\
\hline нрива́я & curve \\
\hline кристалли́ческий & crystalline \\
\hline критика & criticism, review \\
\hline $\begin{array}{l}\text { кроме }(+G) \\
\text { нроме того' }\end{array}$ & $\begin{array}{l}\text { besides, apart from } \\
\text { in addition to that }\end{array}$ \\
\hline epy & circle \\
\hline уби́чесний & cubic \\
\hline уда́ & where to \\
\hline если, куда & if somewhere \\
\hline บ & winged \\
\hline
\end{tabular}

\section{J $\pi$}

лаборато́рный

лан

лакиро́вна

лантанид

левьй

лёгний

легко́

лёгтое

лет (G-pl.: год)

-летие

литерату́ра

лета́ть

лече́ние

лине́йный

Лทния

литий

лишь

луч

Любо́ Й

люди (N-pl.)

$$
\text { M M }
$$

магни́тный магнитстрика́ция мансима́, зьный максиму́m

маленький

малый

матема́тина

меда́ль (fem.)

медици́на

медици́нский

между (+I)

мелиий

менее

меньше

\author{
laboratory(adj.) \\ lacquer \\ lacquering \\ lanthanide \\ left \\ light, easy \\ lightly, easily \\ lung \\ years \\ anniversary \\ literature \\ to fly \\ cure, healing \\ linear \\ line \\ lithium \\ only \\ beam, ray \\ any \\ people \\ magnetic \\ magnetostriction \\ maximal \\ maximum \\ small \\ small \\ mathematics \\ medal \\ medicine \\ medical \\ between, among \\ fine, shallow \\ less \\ less, fewer
}




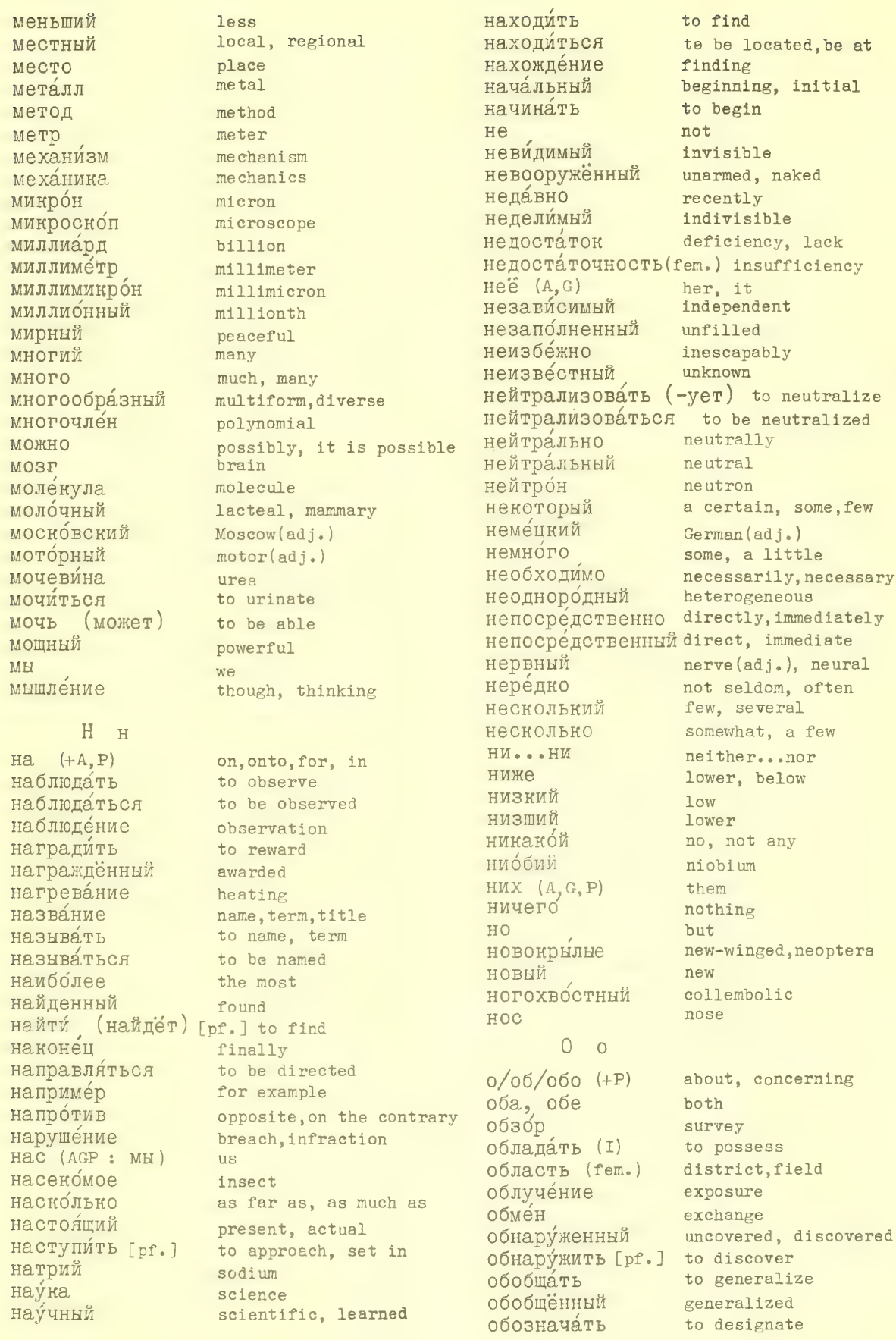




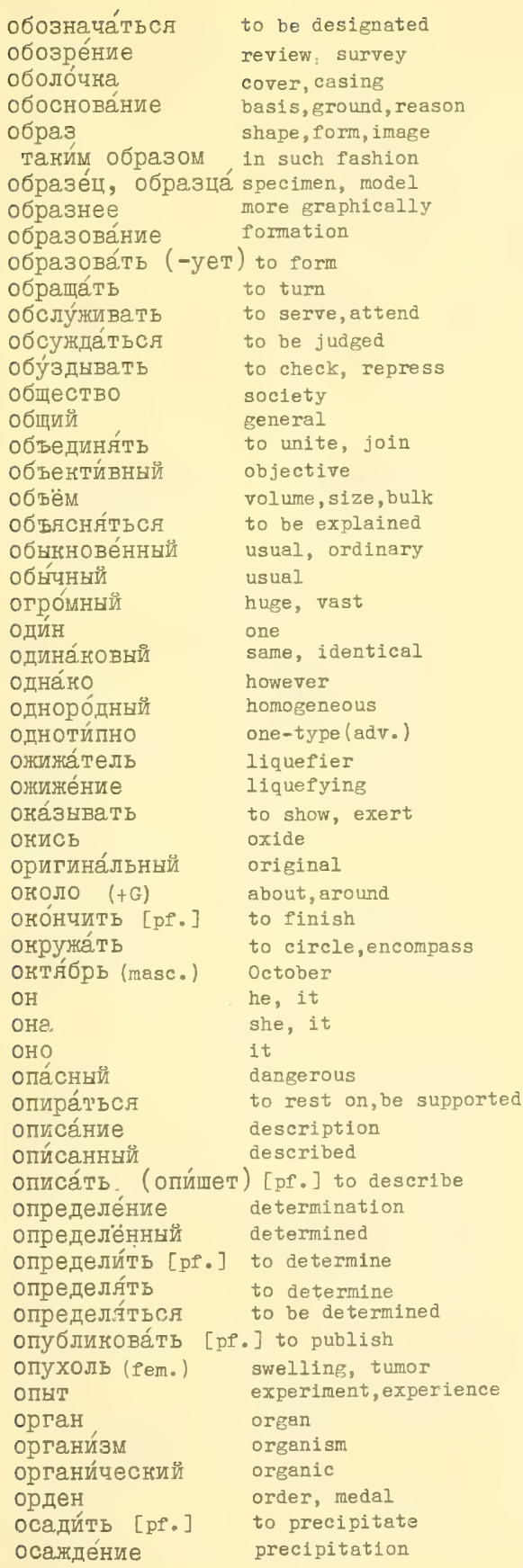

осаждённый

основа́ние

OCHOBHÓ⿻尸丨

B ОСНОВНÓM

осо́бенно

ocó6́

остава́ться

осуществи́ть [рf.

от (+G)
отдел

отделе́ние

откритие

отличаться

отли́чие

в отли́чие от

относи́тьсЯ

отнопе́ние

отодвйнуть (-не

отража́ть

отрасль (fem.)

отрица́тельно

отрица́тельний

отрочество

отря́д

отта́лиивание

отта́лниваться

оттолкну́ться [pf.] to be repelled

оча́r

очаго́вый

очевйдно

очень

очередь (fem.)

очерн

очи́cтra

\section{II $\Pi$}

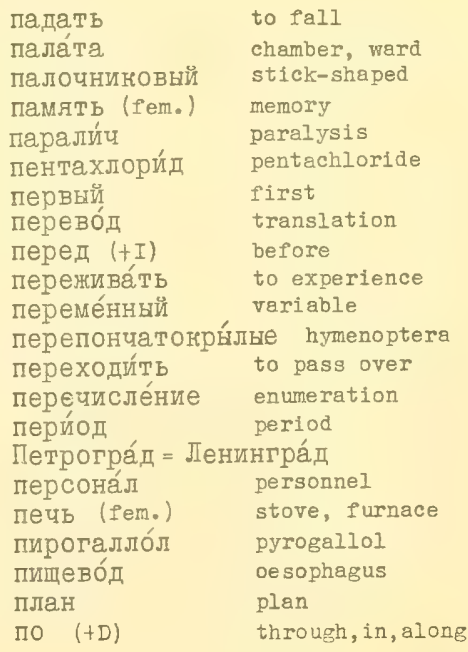

precipitated, deposited

foundation, basis

basic, fundamental

basically

especially

apart, separately, extra

to remain, be left over

realize, accomplish

section, division

division, department

discovery

to be distinguished

distinction

in contrast to, unlike

to relate, pertain, refer relationship, connection

to reflect

branch

negatively

negative

boyhood, girlhood

detachment, branch

repulsion

to be repelled, resisted

focus, nidus

focal, nidal

obviously

very

turn, course, Iine

outline

purification 
побочннй

поведение

secondary, subsidiary

поверхностно

behavior

поверхность (fem.) surface

поम, $(+A, I)$

подальше

пови́димому

подённи

поднла́сc

подотде́л

подстано́вна

подтверди́ть [pf.] substantiate

подходящи й

позво́лить [pf.]

позволя́ть

познано́миться [pf.] to become acquainted

позна́ние

пока́

пока́... не

пока́зывать

поле

полиневри́т

политехничческий polytechnical

полность (fem.) fulness

полньй

полово́й

положе́ние

положи́тельно

положи́тельный

полоеть (fem.), hollow, cavity, void

полужесткокрилые hemiptera

полураспа́д half-life

получа́ть

получа́ться

получе́ние

получченный

пользоваться (-уется) to use

помести́ться [pf.] to be placed in

помеще́ние

помнит в

помощь

попа́сть (попадёт) [pf.] to get(out there)

пора́

до тех пор

поража́ться

пораже́ние

to receive, obtain

to be obtained

receiving, obtaining

received, obtained

room, quarters, space

to remember

$\mathrm{h} \in I \mathrm{p}$

поражение infection, disease

посвяти́ть [pf.] to dedicate

посвящённый

после $(+G)$

после́дний

постро́енный

поступа́ть

почти

поэ́тому

пояснить [pf.]

правоме́рный

прантика

пранти́чески time, it's time

up to that time

to be infected

dedicated, devoted

after

last, latter

built, constructed

to act, behave, go in

almost

for this reason

to explain, illustrate

proportionable, consistent

practice

practically превраща́ться to be converted

превыша́т ь

предме́т

предска́занный predicted

to exceed, go beyond

subject, topic

предста́вить [pf.] to present

представли́ть to present

представля́ть собой to represent

предыду́ший

прежний

преиму́шество

премия

препара́т

преподава́ние

при $(+\mathrm{P})$

при этом

приба́вить [pf.]

прибли́женньй

приблизительно

приведённый

foregoing, preceding

former

advantage

prize

preparation, compound

teaching

at, during, with

besides

to add, augment

approximate, close

approximately

cited, brought forward

привести́ (приведёт) [рf.] to adduce, cite

признава́ть to acknowledge, admit

призна, к

принла́дываться

прили́чие

примене́ние

примени́ть [pf.]

применённый

применя́ть

применя́ться

приме́р

sign, symptom, mark

to be applied

decency

application, use

to apply, use

applied, used

to apply

to be applied

приме́рно

example

about, approximately

принятся, (примется) [pf.] be taken

приобрета́ть to discover, recelve

приорите́т priority

приро́да

присоединя́ться

прису́тствие

притя́гивать

притя́гиваться

притяже́ние

при чи́на

приходи́ться

про $(+\mathrm{A})$

пробле́ма

проведённый

прогресси́вный

nature

to be added, joined to

presence

to attract, araw to

to be attracted

attraction, gravity

reason

to be obliged to, must

about, concerning

problem

conducted, carried out

производи́тельность productivity

производитт то to produce

произво́дная derivative

произво́дство production

проинтегри́рованный integrated

происходить to take place, happen

прова́л

проме́тий

fal1, downfall, dip

promethium

промежутточный intermediate

промы́шленность (fem.) industry

проника́ть

прониннове́ние

просте́йшй to penetrate

penetration, infusion

most common 
просто́ й

простра́нство

протон

профиль (masc.)

проце́сс

прочный

проявля́ть

прямой

пряможрылне

психи́ческий

психо́з

путём $(+G)$

путь (masc.)

пухое́ды

пучо́к

\section{P p}

рабо́та

равенство

равнокри́ль й

равний

равня́ться

радий

радиоаттивный

рапиоко́бальт

ра.до́н

pa3

разбо́рный

развитие

разгляде́ть [pf.]

разде́л

разделе́ние

разделя́ться

разли́чннй

разный

разме́p

разрабо́танный

разрабо́тать [pf.]

разруше́ние

part

ранний

pacrán

располага́ть

располага́ться

располо́женний

распределя́ться

распространённый

рассма́трывать

рассмотрение

расстоя́ние

раство́p

раствори́ться

расчёт

расщепле́ние

рапини́рование

реакти́в

реа́кция

pe да́ттор

редкий common

space, outer space

proton

profile

process

stable

to manifest

straight

orthoptera

psychically

psychosis

by means of, way of

way, road, route

chewing lice, Mallophaga

cluster, beam

work

equality

equal-winged

equal

to be equal to

radium

radloactive

radiocobalt

radon

time

separable, sectional

development

to view

division, section

division, dividing

to be divided

various, different

different, diverse

dimension, size

worked out

to work out

destruction, collapse

cancer

early

disintegration

to dispose, place, set

to be disposed, intend

situated, located

to be distributed

spread out, distributed

to examine

examination, scrutiny

distance

solution

to be dissolved

calculation, account

splitting, pission

refining, purification

reagent, agent

reaction

editor

seldom, rare резкий sharp, abrupt

peктифинацио́нный fractionatin (adj.)

рентисиниа́ция

рентге́новый

rectification

репродунция

$x-\operatorname{ray}\left(a j_{j}\right)$

речь (fem.)

решение

reproduction

speech

decision, solution

pису́нок, рису́нка drawing, sketch

роль (fem.)

рот, рта

родитться [pf.]

ртуть (fem.)

руче́йнии

рлд

руноводи́тель (masc.)

rôle

mouth

to be born

mercury

caddis flies, Trichoptera row, series

leader, guide,manager

C c

$c / c o(+I)$

$c / \mathrm{CO} \quad(+G)$

Ca.m

самостоятельно

самый

сантиме́тр

сборник

све́дение

сверхмо́щны

сверхтену́честь

своеобра́зный

СвОЙ

Связанный

СвОЙство

связь (fem.)

себе́ (D,P)

себя $(A, G)$

сего́дня

ceท̆uác

with

from, off

self

independently

very, most

centimeter

collection

knowledge, information

superpower (adj.)

super-fluidity

singular, unique

one's own

connected

property

connection, bond

one's self

$"$

today

now, at once

секрета́pь (masc.) secretary

сентор

sector

сельсное хози́йство agriculture

семе́йство

family

сензорний

сени́льный

sensory

сеное́ды

senile

серия

сетчатонры́лые

copeognatha

series

neuroptera

сила

сильне́е

power, force

stronger

сильно

сильный

синдро́м

strongly, vigorously

strong

syndrome

систе́ма

system

система́тина

classification

сифилис

syphilis

снонструировать [pf.] to design

снорость (fem.)

speed

снорпионници

scorpions

слебоу́мие 


\begin{tabular}{|c|c|c|c|}
\hline слага́ться & to be composed & струя́ & stream, flow \\
\hline слегка́ & slightly, lightly & ступе́нь (fem.) & step, stage \\
\hline следовать (следу & ret) to follow, must & супйтв & to judge \\
\hline слепующий & the following & суже́ние & narrowing \\
\hline слизистнй & mucous & сульфй́ & sulphide \\
\hline слово & word & суцествова́ние & existence, being \\
\hline слой & layer & схема & scheme, drawing \\
\hline смесь (fem.) & mixture, composite & счита́ть & to count, consider \\
\hline смысл & sense, meanling & счита́ться & to be considered \\
\hline сове́тсний & Soriet & & \\
\hline совреме́нный & contemporary & $\mathrm{T}$ & \\
\hline содерна́ть (соде́р & OHYT) to contain & & \\
\hline содержа́ться & to be contained & Tak & thus, so \\
\hline соедине́ние & compound, combination & тан нан & since \\
\hline создава́ть (созда & êt) to create & так называ́емый & so-called \\
\hline соль (fem.) & salt & также & $11 \mathrm{kew}$ ise \\
\hline сообража́ть & to consider & тано́в, таново́, та & анова́, \\
\hline соображе́ние & consideration & такови́ & such \\
\hline соотве́тственно & according, accordingly & Tarón & such a \\
\hline соотве́тствие & correspondence & тани́м образом & in such manner, thus \\
\hline соотве́тствовать & (-ует) to correspond & танта́.J & tantalum \\
\hline сопротивле́ние & resistance, opposition & тарана́н & cockroech \\
\hline соста́в & composition,formation & твёрдый & firm, hard \\
\hline составля́ть & to constitute & телевипе́ние & television \\
\hline состоя́ние & condition, state & тело & body \\
\hline Состоя́тв (состои́ & IT) to consist (of) & температу́ра & temperature \\
\hline Сотня & hundred & теплопереда́ча & heat transmission \\
\hline сохра́нность & preservation & теплоперено́c & heat transfer \\
\hline социалисти́ческий & sociglistic & тео́рия & theory \\
\hline сочинительство & fantasy & тепе́рь & now \\
\hline спентра́льный & spectral & тепЛово́: & heat $\left(\operatorname{adj} j_{.}\right)$, thermal \\
\hline специальғый & speciel & термин & term \\
\hline способность (fem. & ) ability, capacity & терми́т & termite \\
\hline справка & information, reference & терять & to lose \\
\hline спрессовать [pf.] & to press together & технина & technology, procedure \\
\hline спутник & satellite & тип & type \\
\hline сравне́ние & comparison & тита́н & titanium \\
\hline сравнительный & comparative & тита́новнนี & titanic \\
\hline средний & middle, average & тнань (fem.) & texture, tissue \\
\hline в среднем & on the average & TO & then, in that case \\
\hline $\mathrm{CCCP}$ & USSR & то есть & that is, namely, 1.e. \\
\hline ста.дия & stage, phase & то же самое & the same thing \\
\hline Сталинский & Stalin $\left(\operatorname{ad} j_{.}\right)$ & тогда́ & then \\
\hline старе́ние & ageing & токдество & identity \\
\hline старый & old & Toke & also \\
\hline стать (станет) & [pf.] to become & TOK & current \\
\hline статься (станетс & cя) to happen & ТОЛЬно & only \\
\hline стенло́ & glass & тонкић & thin, fine \\
\hline степень (fem.) & degree, order & топор & axe \\
\hline Стол & table & топохими́ческий. & topochemical \\
\hline 32. столо́м & at the table & TOT, TO, Ta, Te & that, those \\
\hline столе́тие & century & TOपHO & exsctly \\
\hline СтомилЛио́нн Шй & 100-millionth & точныЙ & exact \\
\hline страни́ца & page & травмати́ч ческий & traumatic \\
\hline страдать & to suffer & траекторннй & trajectory (adj.) \\
\hline стреноза & dragon-fly & тремя́ ( & three \\
\hline стремйться & to strive for & третий & third \\
\hline строе́ние & building, structure & Tp'ëx (AGP) & three \\
\hline стройтельнЕй & construction(adj.) & три & three \\
\hline & & трипс & \\
\hline
\end{tabular}




$\begin{array}{ll}\text { труба́ } & \text { pipe, condult } \\ \text { трубочна } & \text { little tube } \\ \text { труд } & \text { work, labor } \\ \text { трудно } & \text { difficult } \\ \text { трудность (fem.) } & \text { difficulty } \\ \text { тулй } & \text { thulium } \\ \text { турбодета́ндер } & \text { turbine-type expansion } \\ & \text { engine }\end{array}$

турбодета́ндерный (adj. for above)

тысяча

тяжеле́е

тяжёлий

thousand

harder, heavier

heavy, difficult

$$
\text { y y }
$$

у $\quad(+G)$

near, with(a person)

увеличе́ние increase

уви́деть (уви́дит) [рf.] to see удава́ться (удаётся) to succeed

удали́ть [pf.] to remove

удо́бне more suitable

упо́бный

удобре́ние

удосто́енный

suitable, convenient

fertilizer

awarded, conferred

уже́

узний

узна́ть [pf.]

уна́занный

уназа́ть (ука́жет) [pf.] to point out

Украи́на

украйнский

уменьша́ться

умственный

университе́т

already

narrow

to find out

pointed out

уничто́нить [pf.]

упа́док, упа́дка

упомянутт [pf.]

употреблять

уравне́ние

ура́н

урожа́.

усло́вие

успе́x

Ukraine

Ukrainian

to be lessened

mental

university

to destroy

decline, fall

to mention, refer

to use

equation

urani um

harvest

condition

success, achievement

устана́вливаться to be established

установи́ть [pf.] to establish

устано́вна

устано́вленнйі

усто́йчивость

устро́йтво

уступа́ть

усугубля́ть

утра́чивать

ухове́рт ти

учённй

учрежпе́ние

$$
\Phi
$$

фантт

installation, apparatus

established.

stability

arrangement, structure

to give in, submit

to redouble, aggravate

to lose, waste

earwigs, dermoptera

scholar, scientist

institution

b.

(2)

factor

last name porcelain(adj.) physicist physics physiologist

physical

form

formula

phosphorous

фосळор

ต้отограби́рование

функция

photegraphing

function

$$
\mathrm{X} \mathrm{x}
$$

характе́рный

characteristic

химиза́ция

ХИМин

Хими์чес ей

Химия

хлоронись

Хобо́тнसй

холод

хоро́штй

хорошо

chemicalization

chemist

chemical

chemistry

oxychloride

proboscis (adj.)

cold

\begin{tabular}{|c|c|}
\hline цветно́й & colored \\
\hline целый & whole \\
\hline в целго & on the whole \\
\hline $\begin{array}{l}\text { цель (fem.) } \\
\text { ценность (fem.) }\end{array}$ & $\begin{array}{l}\text { goal, purpose } \\
\text { value }\end{array}$ \\
\hline центр & center \\
\hline цикЛ & cycle \\
\hline цилиндри́че скй & cylindrical \\
\hline цинк & zinc \\
\hline цирно́ни й & zirconi um \\
\hline
\end{tabular}

good

good, well

$$
\text { บ บ }
$$

части́ца

частична

частншй

часто

часть (fem.)

челове́к

челове́ческий

челюсть (fem.)

чеM

через (+A)

чешуекри́лые

число

чрезвнча́йно

บTO

чт००Н

чувство

particle

very fine particle

private, particular

often

part

person, man

human

jaw

than

throush

lepidoptera

number, date

extremely

that, what

in order to, that

feeling

чувствовать (-ует) to feel 
III UI

wap

широ́кий

широ́ко

школа

щнольн山Й

ए III

\begin{tabular}{|c|c|}
\hline $\begin{array}{l}\text { щаве́левнй } \\
\text { щадя́щй } \\
\text { щёлочь (fem.) } \\
\text { щетиноуво́стнне }\end{array}$ & $\begin{array}{l}\text { oxalic } \\
\text { merciful, sparin } \\
\text { alkali } \\
\text { thysanura }\end{array}$ \\
\hline 50 & \\
\hline өнспериме́нт & experiment \\
\hline өнсперимента́льны & in experimental \\
\hline лектриччески & electrically \\
\hline пентричческий & electricsl \\
\hline лентри́чество & electricity \\
\hline лентро- & electro- \\
\hline
\end{tabular}

\begin{tabular}{|c|c|}
\hline электро́н & electron \\
\hline өлектро́нншй & electronic \\
\hline элеме́нт & element \\
\hline Элемента́рный & elementary \\
\hline әмбии, & Embiidae \\
\hline әмпири́ческий & empirical \\
\hline өне́ргия & energy \\
\hline әнциклопедия & encyclopedia \\
\hline эта́n & stage \\
\hline это & it is, they are \\
\hline өтот, это, эта, & this \\
\hline эти & these \\
\hline
\end{tabular}

ЯВЛЯ́ться

явле́ние

ศEHEII

ядро́

Яกо́ния

япо́нский

яCHO

\author{
to appear, be \\ phenomenon \\ evident, clear \\ nucleus \\ Japan \\ Japanese \\ clearly, it is clear
}


INDE X

Abbreviations 64

Adjectives $\quad$ 14-15

Adverbs from 31

As nouns 15

Comparative 20

Endings $\quad 60-61,14-15$

Paradigms 40

Pronominal 42-43

Short Forms 19

Superlative 20

Adverbs $20,31,52,69-70$

Alphabet 3-9

Cases 10-11,14

Case Usages 17-18

Comparison 20-21,52

Connectives $\quad 67-78$

Consonant Alternations

32

Dictionaries 74-75

Elements 73

Gender 11-12

Gerunds $34-35,57,63$

Impersonal Construction 31

Names 31,42

Négation 29-30

Nouns 10-14,16

Adjective forms 15

Animate 12

Endings $\quad 59,61$

Indeclinable $\quad 16$

Irregular $\quad 50-52$

Paradigms $\quad 36-39$

Numbers 21-22, 44-45

Participles $\quad 32-34,48-49,57,63,71$

Prepositions 16,66-67

Pronouns 19-20,42

Separation rowel o/e 18

Translation 76-77

Questions $30,67-68$
Verbals $32-55$

Verbs

$$
\begin{aligned}
& \text { Aspect 25-27 } \\
& \text { Conditional } 29 \\
& \text { Endings } \quad 62 \\
& \text { Future } \quad 25-26 \\
& \text { Imperative } 23-24 \\
& \text { Infinitive } 22,24-25,53-58 \\
& \text { Irregular } 47 \\
& \text { Past Tense } 22,56 \\
& \text { Present Tense } 22-25,54-55 \\
& \text { Reflexive } \quad 27-28 \\
& \text { Review } 46 \\
& \text { Use of 3rd. pl. } 29 \\
& \text { With Cases } 28
\end{aligned}
$$

\begin{tabular}{|c|c|}
\hline бенать & 47 \\
\hline$\sigma_{\mathrm{H}}$ & 29 \\
\hline ваш & 42 \\
\hline $\mathrm{BeCb}, \mathrm{BC}-$ & 43 \\
\hline время & 41 \\
\hline дать & 47 \\
\hline дети & 41 \\
\hline Дочь & 41 \\
\hline есть "is" & 23 \\
\hline есть "to & eat" $4 ?$ \\
\hline идти & 47 \\
\hline ИМя & 41 \\
\hline нотОрНЙ & 41 \\
\hline нTO & 42 \\
\hline люДИ & 41 \\
\hline мать & 41 \\
\hline MOЙ & 43 \\
\hline HaII & 42 \\
\hline ребёнон & 41 \\
\hline caM & 43 \\
\hline самнй & 43 \\
\hline СВOЙ & 30,43 \\
\hline TOT & 43 \\
\hline хотеть & 47 \\
\hline чеप̆ & 43 \\
\hline человек & 41 \\
\hline чTO & 42 \\
\hline чтобш & 29 \\
\hline ӨTOT & 43 \\
\hline явЛяется & 29 \\
\hline
\end{tabular}

Word Derivation 65-66

Word Order 35

\section{RUSSTAN ENTRIES}









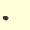


. 


$$
\text { y }
$$

